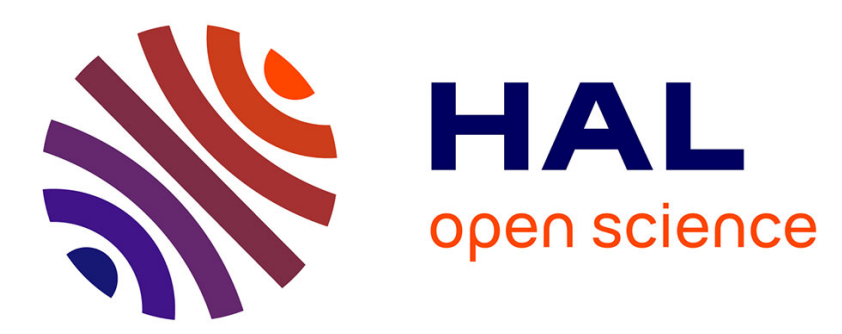

\title{
Experimental evaporation of hyperacid brines: Effects on chemical composition and chlorine isotope fractionation
}

Alejandro Rodríguez, Manfred J van Bergen, H.G.M. G M Eggenkamp

\section{To cite this version:}

Alejandro Rodríguez, Manfred J van Bergen, H.G.M. G M Eggenkamp. Experimental evaporation of hyperacid brines: Effects on chemical composition and chlorine isotope fractionation. Geochimica et Cosmochimica Acta, 2018, 222, pp.467-484. 10.1016/j.gca.2017.10.032 . insu-01867391

\section{HAL Id: insu-01867391 https://hal-insu.archives-ouvertes.fr/insu-01867391}

Submitted on 4 Sep 2018

HAL is a multi-disciplinary open access archive for the deposit and dissemination of scientific research documents, whether they are published or not. The documents may come from teaching and research institutions in France or abroad, or from public or private research centers.
L'archive ouverte pluridisciplinaire HAL, est destinée au dépôt et à la diffusion de documents scientifiques de niveau recherche, publiés ou non, émanant des établissements d'enseignement et de recherche français ou étrangers, des laboratoires publics ou privés. 


\section{Accepted Manuscript}

Experimental evaporation of hyperacid brines: Effects on chemical composition and chlorine isotope fractionation

Alejandro Rodríguez, Manfred J. van Bergen, H.G.M. Eggenkamp

PII:

$$
\text { S0016-7037(17)30695-6 }
$$

DOI: https://doi.org/10.1016/j.gca.2017.10.032

Reference: GCA 10537

To appear in:

$$
\text { Geochimica et Cosmochimica Acta }
$$

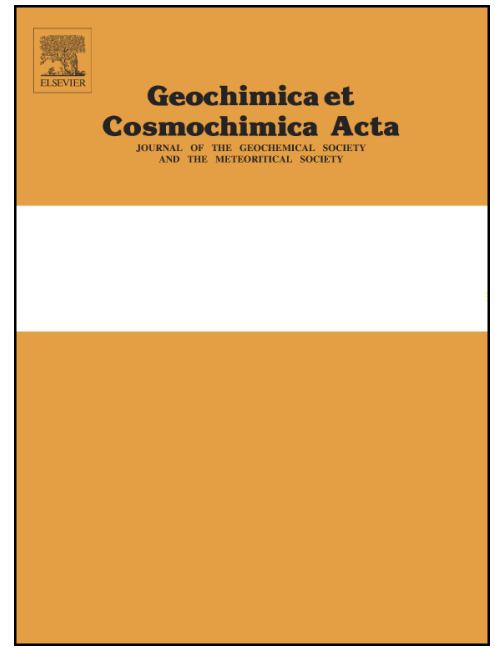

Received Date: 2 November 2016

Accepted Date: $\quad 9$ October 2017

Please cite this article as: Rodríguez, A., van Bergen, M.J., Eggenkamp, H.G.M., Experimental evaporation of hyperacid brines: Effects on chemical composition and chlorine isotope fractionation, Geochimica et Cosmochimica Acta (2017), doi: https://doi.org/10.1016/j.gca.2017.10.032

This is a PDF file of an unedited manuscript that has been accepted for publication. As a service to our customers we are providing this early version of the manuscript. The manuscript will undergo copyediting, typesetting, and review of the resulting proof before it is published in its final form. Please note that during the production process errors may be discovered which could affect the content, and all legal disclaimers that apply to the journal pertain. 


\title{
EXPERIMENTAL EVAPORATION OF HYPERACID BRINES: EFFECTS ON CHEMICAL COMPOSITION AND CHLORINE ISOTOPE FRACTIONATION Alejandro Rodríguez and Manfred J. van Bergen:
}

\author{
Utrecht University
}

\section{Earth Sciences Department}

\author{
Budapestlaan 4
}

3508 TA, Utrecht

Netherlands

Nevertheless, it should be indicated on a foot note that my present address is the following:

\author{
GFZ German Research Centre for Geosciences \\ Section 3.1: Inorganic and isotope geochemistry \\ Telegrafenberg, B458, 14473 Potsdam \\ email: arodrigu@gfz-potsdam.de<mailto:arodrigu@gfz-potsdam.de>
}

\section{H.G.M. Eggenkamp:}

Institut de Physique du Globe de Paris, Équipe de Géochimie des Isotopes Stables, Sorbonne Paris Cité, UMR 7154, CNRS, 1, rue Jussieu, 75238 Paris Cedex 05, France

\begin{abstract}
Hyperacid brines from active volcanic lakes are some of the chemically most complex aqueous solutions on Earth. Their compositions provide valuable insights into processes of elemental transfer from a magma body to the surface and interactions with solid rocks and the atmosphere. This paper describes changes in chemical and $\delta^{37} \mathrm{Cl}$ signatures observed in a 1750 hour isothermal evaporation experiment on hyperacid ( $\mathrm{pH} 0.1$ ) sulphate-chloride brine water from the active lake of Kawah Ijen volcano (Indonesia). Although gypsum was the only evaporite
\end{abstract}


mineral identified in the evolving brine, decreasing $\mathrm{Si}$ concentrations may ultimately result in amorphous silica precipitation. Geochemical simulations predict the additional formation of elemental sulphur at lower water activities $\left(\mathrm{a}_{\mathrm{H}_{2} \mathrm{O}} \leq 0.65\right)$ that were not reached in the experiment. Absence of other sulphates and halides despite the high load of dissolved elements (initial TDS ca. $100 \mathrm{~g} / \mathrm{kg}$ ) can be attributed to increased solubility of metals, promoted by extensive formation of complexes between the variety of cations and the major anions $\left(\mathrm{HSO}_{4}{ }^{-}, \mathrm{Cl}^{-}\right.$ , F-) present. Chlorine deviations from a conservative behaviour point to losses of gaseous hydrogen chloride $\left(\mathrm{HCl}_{(\mathrm{g})}\right)$ and consequently an increase in $\mathrm{Br} / \mathrm{Cl}$ ratios.

Chlorine isotope fractionation that accompanied the escape of $\mathrm{HCl}_{(\mathrm{g})}$ showed a marked change in sign and magnitude in the course of progressive evaporation of the brine. The calculated factor of fractionation between $\mathrm{HCl}_{(\mathrm{g})}$ and dissolved $\mathrm{Cl}$ for the initial interval (before 500 hours) is

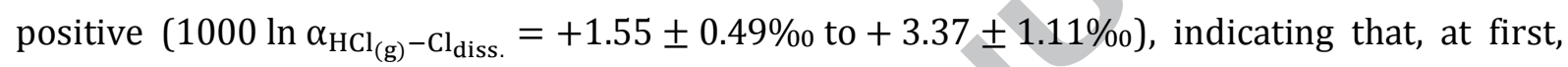
the escaping $\mathrm{HCl}_{(\mathrm{g})}$ was isotopically heavier than the dissolved $\mathrm{Cl}$ remaining in the brine. Conversely, fractionation shifted to the opposite direction in the subsequent interval $\left(1000 \ln \alpha_{\mathrm{HCl}_{(\mathrm{g})}-\mathrm{Cl}_{\mathrm{diss}} .}=5.67 \pm 0.17 \%\right.$ to $-3.97 \pm 0.08 \%$ ), in agreement with values reported in literature. It is proposed that $\mathrm{Cl}$ isotopic fractionation in highly acidic brines is controlled by the distribution of dissolved chlorine species, which changes from $\mathrm{Cl}^{-}$to $\mathrm{HCl}^{\circ}$ dominance with the progressive $\mathrm{pH}$ decline.

The Kawah Ijen lake acquired its extreme composition through influx of sulphur and halogenrich magmatic gas components and extensive rock dissolution. If hyperacid brines with comparable chemical composition existed on Mars, evaporation processes up to the extent reported here $\left(\mathrm{a}_{\mathrm{H}_{2} \mathrm{O}}=0.85\right)$, were likely accompanied by losses of gaseous $\mathrm{HCl}$. The resulting changes in $\mathrm{Cl}$ isotope compositions, $\mathrm{Br} / \mathrm{Cl}, \mathrm{S} / \mathrm{Cl}$ and other ratios in the residual brine might be potentially recorded in assemblages of halogen-bearing secondary evaporation minerals. Also, volcanic-hydrothermal brines as these would extend the stability of liquid water on the Martian surface down to a temperature of $-90^{\circ} \mathrm{C}$.

\section{INTRODUCTION}

Many craters hosted by active volcanoes contain $\mathrm{SO}_{4}$-Cl hyperacid brines, which are complex aqueous solutions from a chemical point of view, being often marked not only by extreme acidity $(\mathrm{pH}<2)$ but also by a high load of dissolved components (TDS $>2 \%$ ) (Rowe et al., 1992; Christenson and Wood, 1993; Delmelle and Bernard, 1994; Kempter and Rowe, 2000; Varekamp et al., 2000; 2009; Rouwet el al., 2014). Evaporation is a major process, contributing to an increase in the concentration of total dissolved 
components and a decrease of volatile species. Under highly acidic conditions gaseous $\mathrm{HCl}$ will escape from the lake surface (Rowe et al. 1992; Rouwet and Ohba, 2015), with volatilization being enhanced by increasing $\mathrm{H}_{2} \mathrm{SO}_{4}$ abundance (lowering $\mathrm{pH}$ ), water temperature or Cl- content (Truesdell et al., 1989; Capaccioni et al., 2016).

Limited chlorine isotope data available for acid crater lakes show a modest $\delta^{37} \mathrm{Cl}$ range between 0.0 and +1.2\%o (Eggenkamp, 1994; Sharp et al., 2010; Rodríguez et al., 2016a), in which any potential effects from fractionation induced by evaporative loss of gaseous $\mathrm{HCl}$ are difficult to deduce. So far, empirical insight into isotopic fractionation between aqueous and gaseous $\mathrm{Cl}$ compounds comes from experimental studies, which have been restricted to simple synthetic systems (Sharp et al., 2010). Equilibrium evaporation experiments on $1 \mathrm{M} \mathrm{HCl}$ performed by these authors resulted in a chlorine isotope fractionation factor between $\mathrm{HCl}$ gas and aqueous chloride $\left(1000 \ln \alpha_{\mathrm{HCl}_{(\mathrm{g})}-\mathrm{Cl}_{(\mathrm{aq})}^{-}}\right)$of $+1.4 \%$ to $+1.8 \%$ o $\left(50-79^{\circ} \mathrm{C}\right)$, closely matching theoretical values reported by Schauble et al. (2003) $\left(+1.7 \% 0 ; 50-100^{\circ} \mathrm{C}\right)$ and Czarnacki and Halas (2012) (+1.55\%o to $+1.69 \%$; $60^{\circ} \mathrm{C}$ ). However, Sharp et al. (2010) also conducted evaporation experiments on concentrated hydrochloric acid $(11.6 \mathrm{M})$ in an open system at room temperature, which resulted in a negative value of $-4.0 \%$. They proposed that, in this case, $\mathrm{HCl}_{(\mathrm{g})}$ is relatively depleted in ${ }^{37} \mathrm{Cl}$ because the kinetic effect associated with the higher translational velocity of $\mathrm{H}^{35} \mathrm{Cl}$ predominates over the equilibrium fractionation between $\mathrm{HCl}_{(\mathrm{g})}$ and $\mathrm{Cl}^{-}$ (aq) in which ${ }^{37} \mathrm{Cl}$ preferentially partitions into the $\mathrm{HCl}_{(\mathrm{g})}$.

This paper extends this experimental work to more complex natural aqueous solutions, and describes the effects of evaporation on the chemical and $\mathrm{Cl}$ isotopic composition of $\mathrm{SO}_{4}-\mathrm{Cl}$ hyperacid brine from an active volcanic crater lake. The results are potentially relevant for interpretations of the mineralogical marks that fluids have left on the surface of Mars. Firstly, the former presence of $\mathrm{SO}_{4}-\mathrm{Cl}$ acidic brines on Mars has been invoked to explain the high concentrations of sulphur and chlorine found by Viking, Pathfinder and MER (Mars Exploration Rovers) Opportunity and Spirit in soils and rock weathering rinds (Brass, 1980; Clark and Van Hart, 1981; Bell et al., 2000; Clark et al., 2005; Tosca and McLennan, 2006; Zolotov and Mironenko, 2007; Schmidt et al., 2008). These findings indicate that probably substantial volcanic degassing of volatile-rich magmas occurred on Mars throughout time (Gellert et al., 2004; Haskin et al., 2005; Gellert et al., 2006). The water-gas-rock interaction processes that once operated at or 
near the surface of Martian sulphate-rich terrains may have been similar to those of active terrestrial systems with hyperacid lakes, in view of similarities in alteration mineralogy and element distributions (Rodríguez and van Bergen 2015, Rodríguez et al. 2016b; Rodríguez and van Bergen 2017). The analogy is supported by experimental constraints on the evaporative evolution of acid-sulphate solutions equivalent to those derived from the chemical weathering of synthetic Martian basalt (Tosca and McLennan, 2009). Furthermore, acidic brines are particularly relevant because large amounts of dissolved components could strongly increase the stability of liquid $\mathrm{H}_{2} \mathrm{O}$ on Mars by depressing the freezing point and extending its P-T field (Mölhmann and Thompsen, 2011; Elsenousy et al., 2015). Finally, minerals formed as result of evaporation or freezing processes might be an important $\mathrm{H}_{2} \mathrm{O}$-sink on Mars' surface and could have played a major role in controlling acidity and salinity of Martian paleo-fluids and hence the habitability on this planet (Knauth and Burt, 2002; Toner et al., 2015).

The brine used in the experiment comes from the hyperacid lake of Kawah Ijen, an active andesitic stratovolcano located at the rim of Ijen caldera, the easternmost volcanic complex on Java, Indonesia. This crater lake is one of the world's largest bodies of natural hyperacid brine, and is characterized by a high load of dissolved elements (often $>100 \mathrm{~g} / \mathrm{l})$, very low pH $(<1)$ and very high concentrations of chlorine (often $>20000$ $\mathrm{mg} / \mathrm{kg}$ ), sulphate (often $>60000 \mathrm{mg} / \mathrm{kg}$ ) and rock-forming elements $\mathrm{Al}, \mathrm{Fe}, \mathrm{Ca}, \mathrm{Mg}, \mathrm{Na}, \mathrm{K}$ and Si (Delmelle and Bernard, 1994; Delmelle et al., 2000; van Hinsberg et al., 2010; Caudron et al., 2017). The Kawah Ijen lake water type is typically found on active volcanic crater lakes. These waters normally present $\mathrm{pH}$ values between 2 and -1 , and concentrations of $\mathrm{Cl}^{-}+\mathrm{SO}_{4}{ }^{2-}$ between 3000 and $300000 \mathrm{mg} / \mathrm{kg}$ (Varekamp et al., 2000).

\section{METHODS}

\subsection{Evaporation experiment}

The Kawah Ijen brine selected for the evaporation experiment was collected on October $30^{\text {th }}, 2002$ and has been employed as in-house standard for hyperacid brine analysis at the Department of Earth Sciences at Utrecht University. The total amount of brine used for the experiment $(1.4 \mathrm{l})$ was filtered through a $0.2 \mu \mathrm{m}$ pore size cellulose acetate membrane to remove amorphous silica and gypsum that had precipitated upon storage for many years. A total of 26 plastic Greiner ${ }^{\circledR}$ tubes were filled with approximately 50 
$\mathrm{ml}$ brine, and were collectively placed on a plastic rack that was partially submerged in a water bath at $60^{\circ} \mathrm{C}$ (Fig. 1). The initial weight of all samples was recorded before the evaporation experiment started.

The experiment lasted 1750 hours (73 days) during which duplicate samples were removed from the water bath at certain time intervals. Directly after removal, the final weight, $\mathrm{pH}$ and electrical conductivity, measured at room temperature $\left(20 \pm 1^{\circ} \mathrm{C}\right)$, were determined for each sample. Next, six aliquots of approximately 1.6, 0.6 and 0.2 grams were diluted 10, 25 and 100 times with deionised water for IC (ion-chromatography) analysis, and 10, 25 and 100 times with 2\% Suprapur® $\mathrm{HNO}_{3}$ solution for ICP-OES (inductively coupled plasma optical emission spectrometry) analysis. Towards the end of the evaporation experiment, some samples had to be further diluted up to 650 times for IC analysis. The pH and conductivity measurements were performed with a WTW® 3430 portable multimeter at room temperature $\left(20^{\circ} \mathrm{C}\right)$. The $\mathrm{pH}$ electrode was calibrated with $\mathrm{pH} 1,4$ and 7 buffers. The conductivity electrode was calibrated with a $0.01 \mathrm{M} \mathrm{KCl}$ standard. Both electrodes were calibrated before every measurement. The acicular crystals formed during the experiment where separated from the solutions by filtration through a $0.2 \mu \mathrm{m}$ pore size cellulose acetate membrane, washed with deionized water and finally dried overnight at $60^{\circ} \mathrm{C}$.

\subsection{Analytical methods}

\subsubsection{Major elements}

The fluoride concentrations were determined by ion chromatography (IC), using a Dionex ${ }^{\circledR}$ ICS-3000, equipped with a Dionex ${ }^{\circledR} \operatorname{IonPac}^{\circledR}$ AS 19 column. A gradient elution of $10-50 \mathrm{mM} \mathrm{KOH}$ was utilized. Total sulphur $\left(\mathrm{S}_{\mathrm{T}}\right), \mathrm{Cl}, \mathrm{Al}, \mathrm{B}, \mathrm{Br}, \mathrm{Ca}, \mathrm{Fe}, \mathrm{K}, \mathrm{Mg}, \mathrm{Na}, \mathrm{Si}, \mathrm{Sr}$ and $\mathrm{Ti}$ were analysed by inductively coupled plasma optical emission spectrometry (ICP-OES) with a Spectro ${ }^{\circledR} \operatorname{Ciros}^{\circledR}$ instrument. The average relative uncertainties on the analysis where the following: $1 \%\left(\mathrm{~S}_{\mathrm{T}}\right.$ and $\mathrm{Si}$ ); $2 \%$ (B, Br, Ca, Fe, K, Mg, $\mathrm{Na}$ and $\mathrm{Sr}$ ); 3\% (Al and $\mathrm{Cl}$ ) and 4\% (Ti and F). All the aforementioned analyses where carried out at the Department of Earth Sciences, Utrecht University.

\subsubsection{Chlorine isotopes}


Samples for $\delta^{37} \mathrm{Cl}$ analysis were prepared following a variation of the method described by Kaufmann (1984) and Eggenkamp (1994). Based on the $\mathrm{Cl}$ concentrations determined by ICP-OES, an aliquot of an undiluted sample from the evaporation experiment was treated with $4 \mathrm{ml}$ of $1 \mathrm{M} \mathrm{KNO}_{3}, 1 \mathrm{ml}$ of $\mathrm{H}_{2} \mathrm{O}_{2}$ (30 wt.\%) and $1 \mathrm{ml}$ of concentrated $\mathrm{HNO}_{3}$ (65 wt.\%). Then this mixture was heated to $80^{\circ} \mathrm{C}$ for 30 minutes before $1 \mathrm{ml}$ of $0.2 \mathrm{M} \mathrm{AgNO}_{3}$ was added. In this way, approximately $10 \mathrm{mg}$ of $\mathrm{AgCl}$ were precipitated from each sample and collected after filtering through a Whatman ${ }^{\circledR}$ type $\mathrm{GF} / \mathrm{F}$ glass fibre and finally dried overnight at $80^{\circ} \mathrm{C}$. Subsequently, the $\mathrm{AgCl}$ was reacted with iodomethane $\left(\mathrm{CH}_{3} \mathrm{I}\right)$ in order to form chloromethane $\left(\mathrm{CH}_{3} \mathrm{Cl}\right)$ at $70-80^{\circ} \mathrm{C}$ during 48 hours in vacuum glass ampoules. The chloromethane was separated from the excess $\mathrm{CH}_{3} \mathrm{I}$ by gas chromatography using a $75 \mathrm{~cm}$ long, $6.35 \mathrm{~mm}$ OD SS column, filled with Porapak $^{\circledR} \mathrm{Q} 80-100$ mesh at $140^{\circ} \mathrm{C}$ with helium as carrier gas. The analyses of $\mathrm{CH}_{3} \mathrm{Cl}$ were carried out on a VG SIRA 24 EM mass spectrometer at the Department of Earth Sciences of Utrecht University. As shown in equation (1), chlorine isotope data are reported as a delta notation $\left(\delta^{37} \mathrm{Cl}\right)$ using a reference sample of sea water from the Atlantic Ocean collected near Madeira in 1982, known as Standard Mean Ocean Chloride or SMOC (Kaufmann, 1984). The analytical accuracy was $\pm 0.16 \%$ ( $1 \sigma$ ) based on longterm analyses of this standard. Nevertheless, samples were analysed at least in duplicate and the averages were accepted if the difference between duplicates was $\leq 0.10 \%$.

$$
\delta^{37} \mathrm{Cl}(\% \mathrm{O})=\frac{\left({ }^{37} \mathrm{Cl} /{ }^{35} \mathrm{Cl}\right)_{\text {sample }}-\left({ }^{37} \mathrm{Cl} /{ }^{35} \mathrm{Cl}\right)_{\text {SMOC }}}{\left({ }^{37} \mathrm{Cl} /{ }^{35} \mathrm{Cl}\right)_{\text {SMOC }}} \times 1000
$$

\subsubsection{Chemical composition of the precipitate}

Raman spectra were obtained from the precipitate (acicular crystals) formed during the experiment using a $532 \mathrm{~nm}$ wavelength Nd-YAG laser. An optical microscope with a $50 \mathrm{x}$ long working distance objective lens provided a laser spot size of $\sim 2 \mu \mathrm{m}$ at the sample surface. The scattered light was dispersed using a grating of 600 grooves/mm before being collected on a charge coupled device camera. Each spectrum was acquired 20 times with an integration time of 0.2 seconds. Detailed images were also obtained from carbon-coated crystals with a JEOL JCM-6000 Benchtop SEM. Spot analysis were performed on carbon-coated crystals with a JEOL JXA-8530F field-emission-electron- 
microprobe. The beam conditions were $15 \mathrm{kV}, 10 \mathrm{nA}$ and $20 \mu \mathrm{m}$ diameter; scans were also done with a defocused $10 \mu \mathrm{m}$ beam.

\subsection{Geochemical modelling}

The geochemical modelling software PHREEQC, version 3.1 (Parkhurst and Appelo, 1999), was used to calculate aqueous species distributions and mineral saturation states. The Lawrence Livermore National Laboratories thermodynamic database (llnl.dat) was used. Additionally, ion interaction parameters from many ion pairs were included (Pitzer and Mayorga, 1973). The $\mathrm{pH}$ values at $60^{\circ} \mathrm{C}$ were recalculated by charge balance with PHREEQC, as it is recommendable for extremely acid waters (Nordstrom et al., 2000).

\section{RESULTS}

\subsection{Evaporation rates}

The total duration of the evaporation experiment was 1750 hours ( $\sim 73$ days). The weight loss of the brine virtually stopped after 1340 hours (samples 12 and 13) when a maximum of $58 \%$ was reached. (Fig. 2; Table 1). Evaporation rates were calculated taking the transversal area of the Greiner ${ }^{\circledR}$ tubes $\left(0.0601 \mathrm{dm}^{2}\right)$ into account. The brine exhibited a decrease in evaporation rates throughout the experiment. In particular, around 400 hours, the brine showed a marked decrease (from 1.01 to $0.83 \mathrm{~g} / \mathrm{h} / \mathrm{dm}^{2}$ ), after which there was a smooth decline until the end of the experiment.

\subsection{Chemical composition, mineral saturation states and speciation in the brine}

The hyperacid $\mathrm{SO}_{4}-\mathrm{Cl}$ composition of the Kawah Ijen brine is a result of the condensation of magmatic $\mathrm{SO}_{2}, \mathrm{HCl}, \mathrm{HF}$ and $\mathrm{HBr}$ gases in water of largely meteoric origin. The acidity comes mainly from $\mathrm{HSO}_{4}$ - dissociation, together with contributions of $\mathrm{HCl}_{(\mathrm{aq})}, \mathrm{HF}_{(\mathrm{aq})}$ and $\operatorname{HBr}_{(\mathrm{aq})}$ (Giggenbach, 1975; 1987). Because of the strong acidity, the fluid contains high concentrations of rock-forming elements such as $\mathrm{Ca}, \mathrm{Al}, \mathrm{Fe}, \mathrm{Mg}, \mathrm{Na}, \mathrm{K}$ and $\mathrm{Si}$ derived from the dissolution of primary minerals and glass. At the start of the experiments, the initial concentrations of total sulphur $\left(\mathrm{S}_{\mathrm{T}}\right), \mathrm{Cl}, \mathrm{F}, \mathrm{Br}, \mathrm{Al}, \mathrm{Fe}, \mathrm{K}, \mathrm{Na}, \mathrm{Ca}$, and $\mathrm{Mg}$ in the brine were 21800, 22100, 1410, 56, 5730, 1970, 1230, 1110, 690 and $690 \mathrm{mg} / \mathrm{kg}$, respectively. Total dissolved solids (TDS) were $96 \mathrm{~g} / \mathrm{kg}$ and $\mathrm{pH}$ was $0.10\left(20 \pm 1^{\circ}\right)$. At the end of the 
experiment, upon $58 \mathrm{wt}$ \% of evaporation, the final concentrations were (in the same order): 52400, 45900, 3110, 124, 13800, 4920, 2920, 2610, 700 and $1630 \mathrm{mg} / \mathrm{kg}$. The total dissolved solids increased up to $234 \mathrm{~g} / \mathrm{kg}$, and $\mathrm{pH}$ decreased to $-0.41\left(20 \pm 1^{\circ}\right)$ (Table 2).

In order to explore elemental losses by mineral precipitation or evaporation of volatile phases, time series were plotted for ratios of element concentrations against $\mathrm{Mg}$, adopted as a perfectly conservative solute (Fig. 3). Notable negative deviations from a horizontal trend in the ratio plots indicate removal of $\mathrm{Cl}, \mathrm{Ca}, \mathrm{Sr}$ and $\mathrm{Si}$ during some intervals in the evaporation process. The $\mathrm{Cl} / \mathrm{Mg}$ ratio shows a steady decline virtually from the start (Fig. 3a), indicating an escape of gaseous $\mathrm{HCl}$ from the brine throughout the experiment, in absence of a Cl-bearing precipitating solid phase. There is a concomitant gradual increase of $\log f_{\mathrm{HCl}}$ values in the course of the experiment (Fig. 4a). Conversely, the $\mathrm{Br} / \mathrm{Mg}$ ratio remains largely constant although a decreasing tendency is suggested for the starting interval (Fig. 3b). The increase of $\log f_{H B r}$ values was relatively small (Fig. $4 \mathrm{a}$ ).

The Ca depletion in the brine after 594 hours (Fig. 3c) coincides with the appearance of acicular crystals from sample 10 (762 hours) onward until the end of the experiment. According to Raman spectra and electron backscatter imaging (Figs. 5a and 5b), together with semi-quantitative EPMA-WDS analysis this phase is gypsum $\left(\mathrm{CaSO}_{4} \cdot 2 \mathrm{H}_{2} \mathrm{O}\right)$, containing appreciable amounts of $\mathrm{Sr}$ (average $700 \pm 200 \mathrm{ppm}$ ). The decrease of the $\mathrm{Sr} / \mathrm{Mg}$ follows the same timing as that of $\mathrm{Ca} / \mathrm{Mg}$ (Fig. 3c). Hence, precipitation of gypsum explains the gradual depletion of both $\mathrm{Ca}$ and $\mathrm{Sr}$, since the latter can substitute $\mathrm{Ca}$ (Ichikuni and Musha, 1978; Kushnir, 1980). Celestine ( $\left.\mathrm{SrSO}_{4}\right)$ was not detected and remained far from saturation (Fig. 4b).

Silicon concentrations exhibit a significant decrease towards the end of the experiment as is expressed in the $\mathrm{Si} / \mathrm{Mg}$ decline after 930 hours (Fig. 3d). Because no silica-bearing solid phase was directly detected by SEM analyses, it is conceivable that escape of gaseous $\mathrm{SiF}_{4(\mathrm{~g})}$ could be responsible for the $\mathrm{Si}$ loss. However, this option is difficult to substantiate with the F/Mg trend, from which no obvious loss of fluorine can be deduced (Fig. 3b). On the other hand, it must be realized that the fluorine required to match the loss of silicon as $\mathrm{SiF}_{4(\mathrm{~g})}$ is too little, compared to the amount of dissolved $\mathrm{F}(>1410$ 
$\mathrm{mg} / \mathrm{kg}$ ), to be noticeable within the analytical error. Alternatively, the apparent Si loss resulted from the precipitation of amorphous silica particles, which remained unobserved because of their small size and quantity (see Discussion). Other element/Mg ratios display horizontal trends (Figs. 3e and 3f), suggesting a conservative behaviour.

As Figure 4b illustrates, Ca-sulphates and amorphous silica were the only major-element hosts that approached saturation closest in the PHREEQC models. Calculated fugacities of $\mathrm{HCl}_{(\mathrm{g})}, \mathrm{HBr}_{(\mathrm{g})}$ and $\mathrm{SiF}_{4(\mathrm{~g})}$ show increases with time (Fig. 4a). The behaviour of $\mathrm{Ti}$ is governed by anatase $\left(\mathrm{TiO}_{2}\right)$, which is commonly saturated in the Kawah Ijen lake (Delmelle and Bernard, 1994; Delmelle et al., 2000). During the experiment, the concentrations of dissolved $\mathrm{Ti}$ were close to equilibrium (Figs. 3f and $4 \mathrm{~b}$ ), taking analytical uncertainty into account. Fluorite $\left(\mathrm{CaF}_{2}\right)$, cryolite $\left(\mathrm{AlF}_{3}\right)$ and halite $(\mathrm{NaCl})$ remained always well undersaturated, showing an initial increase in saturation indices (SI), followed by a levelling off (Fig. a, Supplementary Electronic Annex EA-1). Iron and magnesium sulphates remained undersaturated throughout the experiment. The saturation indices of szolmolnokite $\left(\mathrm{FeSO}_{4} \cdot \mathrm{H}_{2} \mathrm{O}\right)$, rozenite $\left(\mathrm{FeSO}_{4} \cdot 4 \mathrm{H}_{2} \mathrm{O}\right)$, siderotile $\left(\mathrm{FeSO}_{4} \cdot 5 \mathrm{H}_{2} \mathrm{O}\right)$, ferrohexahydrite $\left(\mathrm{FeSO}_{4} \cdot 6 \mathrm{H}_{2} \mathrm{O}\right)$ and melanterite $\left(\mathrm{FeSO}_{4} \cdot 7 \mathrm{H}_{2} \mathrm{O}\right)$ show an initial increase, then a decline and finally an increase again towards the end of the experiment (Fig. b, EA-1). The SI values of kieserite $\left(\mathrm{MgSO}_{4} \cdot \mathrm{H}_{2} \mathrm{O}\right)$, starkeyite $\left(\mathrm{MgSO}_{4} \cdot 4 \mathrm{H}_{2} \mathrm{O}\right)$, pentahydrite $\left(\mathrm{MgSO}_{4} \cdot 5 \mathrm{H}_{2} \mathrm{O}\right)$, hexahydrite $\left(\mathrm{MgSO}_{4} \cdot 6 \mathrm{H}_{2} \mathrm{O}\right)$ and epsomite $\left(\mathrm{MgSO}_{4} \cdot 7 \mathrm{H}_{2} \mathrm{O}\right)$ increased steadily with time (Fig. c, EA-1).

In summary, the only phases that formed upon brine evaporation were $\mathrm{HCl}_{(\mathrm{g})}$, gypsum and a Si-bearing phase (probably amorphous $\left.\mathrm{SiO}_{2}\right)$. Anatase $\left(\mathrm{TiO}_{2}\right)$ was in equilibrium and its presence could not be detected by the analysis.

Total dissolved chlorine $\left(\mathrm{Cl}_{\text {diss. }}\right)$ is present in the form of undissociated hydrogen chloride $\left(\mathrm{HCl}^{0}\right)$ and $\mathrm{Cl}^{-}$, with the activity of the latter species being dominant (Fig. 6). When evaporation proceeded, the activity of $\mathrm{HCl}^{0}$ increased strongly, reflecting displacement of the equilibrium of reaction (2) to the left hand side due to the increase of $\mathrm{H}_{3} \mathrm{O}^{+}$. The same mechanism favoured the formation of $\mathrm{H}_{2} \mathrm{SO}_{4}{ }^{0}$ and $\mathrm{HBr}^{0}$, but activities of these species were several orders of magnitude lower than that of $\mathrm{HCl}^{0}$ (reactions 3 and 4) (Fig. 6). 


$$
\begin{gathered}
\mathrm{HCl}^{0}+\mathrm{H}_{2} \mathrm{O} \Leftrightarrow \mathrm{Cl}^{-}+\mathrm{H}_{3} \mathrm{O}^{+} \\
\mathrm{H}_{2} \mathrm{SO}_{4}+\mathrm{H}_{2} \mathrm{O} \Leftrightarrow \mathrm{HSO}_{4}^{-}+\mathrm{H}_{3} \mathrm{O}^{+} \\
\mathrm{HBr}^{0}+\mathrm{H}_{2} \mathrm{O} \Leftrightarrow \mathrm{Br}^{-}+\mathrm{H}_{3} \mathrm{O}^{+}
\end{gathered}
$$

Aluminium has a strong tendency to form complexes with $\mathrm{F}^{-}$, so that most of this element is present as $\mathrm{AlF}_{2}+, \mathrm{AlF}^{2+}$ and $\mathrm{AlF}_{3}$ (Fig. a, EA-2). On the other hand, $\mathrm{Fe}^{2+}$ and $\mathrm{Fe}^{3+}$ are predominantly complexed with $\mathrm{Cl}^{-}$, forming $\mathrm{FeCl}^{+}$and $\mathrm{FeCl}^{2+}$, respectively (Figs. b and c; EA-2). It should be mentioned that, due to the extreme acidity of the Kawah Ijen brine, iron is predominantly in its lower oxidation state $\left(\mathrm{Fe}^{2+}\right)$. Magnesium and calcium are mainly present as $\mathrm{Mg}^{2+}$ and $\mathrm{Ca}^{2+}$, respectively, but also form complexes with $\mathrm{SO}_{4}{ }^{2-}$ and $\mathrm{Cl}^{-}$such as $\mathrm{MgCl}^{+}, \mathrm{MgSO}_{4}{ }^{0}, \mathrm{CaCl}^{+}$and $\mathrm{CaSO}_{4}{ }^{0}$, where the sulphur-bearing species always have higher activities than their chlorine-bearing counterparts (Figs. d and e; EA2). Finally, potassium and sodium tend to remain largely as $\mathrm{K}^{+}$and $\mathrm{Na}^{+}$, with the most significant complexes being $\mathrm{KHSO}_{4}{ }^{0}$ and $\mathrm{NaCl}^{0}$, respectively (Figs. $\mathrm{f}$ and g; EA-2). The dominant strontium species in the early part of the experiment was $\mathrm{Sr}^{2+}$, which decreased rapidly in favour of the $\mathrm{SrCl}^{+}$and $\mathrm{SrSO}_{4}{ }^{0}$ complexes (Figure h, EA-2). The apparent strong reduction of $\mathrm{Sr}^{2+}$ availability in the course of the experiment may explain our observation that the precipitated gypsum incorporated 3-4 times less strontium than expected from low-temperature gypsum-solution partitioning data (Ichikuni and Musha, 1978; Kushnir, 1980).

\subsection{Chlorine isotope trends and $\mathrm{Cl}$ losses}

From the initial $\delta^{37} \mathrm{Cl}$ composition of the hyperacid brine $(+0.36 \pm 0.05 \%$ ) until sample 9 ( 500 hours), a slight decrease down to $+0.22 \pm 0.04 \%$ o was observed. This trend was followed by a significant increase up to $+0.68 \pm 0.05 \%$ in the last sample (Table 3, Fig. 7). The changes in isotope composition are accompanied by chlorine losses through escaping $\mathrm{HCl}_{(\mathrm{g})}$, given the absence of any solid precipitating Cl-bearing phase during the experiment. The $\mathrm{HCl}_{(\mathrm{g})}$ degassing of the brines probably started early (Fig. 3a), but the significant increase in $\log f_{\mathrm{HCl}}$ values after 500 hours (Fig. 4a) suggests an enhancement from that moment on.

Chlorine losses by degassing $\mathrm{HCl}_{(\mathrm{g})}$ were calculated from the differences between measured and calculated $\mathrm{Cl}$ concentrations (Table 3). The concentration differences 
were transformed into mass losses (mg) for each sample, based on the remaining liquid mass (Table 1). Fractionation between $\mathrm{HCl}_{(\mathrm{g})}$ and total dissolved chlorine $\left(\mathrm{Cl}_{\text {diss. }}\right)$ during the evaporation experiment can be calculated using the Rayleigh fractionation model:

$$
\delta_{f}-\delta_{i}=\left(1000+\delta_{i}\right)\left(F^{(\alpha-1)}-1\right)
$$

Where $\delta_{\mathrm{i}}$ and $\delta_{\mathrm{f}}$ are the $\delta^{37} \mathrm{Cl}$ composition for the initial Kawah Ijen brine $(+0.36 \pm 0.05 \%$; sample $\mathrm{t}=0)$ and the subsequent $\delta^{37} \mathrm{Cl}$ compositions throughout the evaporation experiment, respectively. The fractionation factor is $\alpha$, and $F$ is the total chlorine remaining in the liquid, defined by:

$$
F=\frac{C l_{\text {final }}(m g)}{C l_{\text {initial }}(m g)}
$$

Expressing equation (5) in a linear form gives:

$$
\ln \left(\frac{\delta_{f}+1000}{\delta_{i}+1000}\right)=(\alpha-1) F
$$

Where $\alpha$ can be obtained from the slope of the line. The experiments yielded two

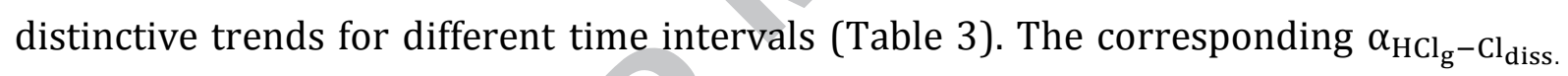
values are 1.00300 $\pm 0.000002(\mathrm{t}=0-500$ hours $)$ and 0.994479 $\pm 0.000004(\mathrm{t}=500-1750$ hours) (Fig 8a). The fractionation factors (1000 $\ln \alpha_{\mathrm{HCl}_{\mathrm{g}}-\mathrm{Cl}_{\text {diss. }}}$ ) before and after 500 hours, are $+2.963 \pm 0.014 \%$ and $-5.536 \pm 0.004 \%$, respectively (Fig 9a). This implies that the $\mathrm{HCl}_{(\mathrm{g})}$ produced during the first 500 hours of the experiment was enriched in ${ }^{37} \mathrm{Cl}$ compared to the $\mathrm{Cl}_{\text {diss. }}$ in the hyperacid brine, whereas after 500 hours it was depleted in ${ }^{37} \mathrm{Cl}$.

An alternative approach to calculate these fractionation factors is by using $F$ values derived from the ratio between $\mathrm{Cl}$ and a conservative element such as boron. For each sample, the $\mathrm{Cl} / \mathrm{B}$ ratio was determined and normalized to the ratio in the initial brine (sample $\mathrm{t}=0$ ). In this case:

$$
C l_{\text {final }}(m g)=C l_{\text {initial }}(m g)\left(\frac{C l_{\text {final }} / B_{\text {final }}}{C l_{\text {initial }} / B_{\text {initial }}}\right)
$$

and then,

$$
C l_{\text {initial }}(m g)-C l_{\text {final }}(m g)=C l_{\text {loss }}=H C l_{(g)}
$$


The resulting $F$ values and fractionation factors were again obtained from equations (6) and (7) by linear regression, assuming Rayleigh fractionation (EA-3) (Figs. 8b and 9b). In a similar way, $F$ values and fractionation factors were also calculated for Fe and $\mathrm{Mg}$ as conservative elements (EA-3), (Figs. 8c, 8d, 9c and 9d) and essentially the same results were obtained (Table 4).

\section{DISCUSSION}

According to experiments and models reported in literature, calcium sulphates are often the first phases to precipitate upon evaporation of saline brine waters, followed by a variety of $\mathrm{K}, \mathrm{Mg}, \mathrm{Fe}^{2+}$ and $\mathrm{Fe}^{3+}$-sulphates (Tosca and McLennan, 2006; 2009; Gamazo et al., 2011; Elsenousy et al., 2015; Toner et al., 2015). In evaporation experiments on a Clbearing acid-sulphate fluid with a composition derived from chemical weathering of a synthetic olivine-bearing Martian basalt, Tosca and McLennan (2009) found gypsum, Mg-rich voltaite, an unidentified (Mg,Fe)-sulphate-heptahydrate and rhomboclase as precipitating minerals. The concomitant changes in solution chemistry were first a loss of $\mathrm{Ca}$ and a further depletion of $\mathrm{K}, \mathrm{Al}, \mathrm{Fe}, \mathrm{Mg}$ and $\mathrm{SO}_{4}$ towards the end of the run when most of $\mathrm{H}_{2} \mathrm{O}$ was evaporated. No detectable fractionation of $\mathrm{Cl}$ occurred. The authors inferred that sulphate mineralogy and chemical evolution of the solution did not follow an equilibrium pathway predicted by thermodynamic models but were influenced by kinetic controls on the precipitation of copiapite-group minerals. Gamazo et al. (2011) modelled the evaporation of $\mathrm{Mg}-\mathrm{Na}-\mathrm{Cl}-\mathrm{SO}_{4}$ brine water from Quero lake (Spain), and observed the appearance of an anhydrite-gypsum paragenesis at $a_{\mathrm{H}_{2} \mathrm{O}}=0.78$, followed by epsomite-hexahydrite and hexahydrite-kieserite paragenesis at $a_{\mathrm{H}_{2} \mathrm{O}}$ values of 0.57 and 0.50 , respectively. Similarly, based on the Na-K-Ca-Mg-Cl-SO ${ }_{4}-\mathrm{ClO}_{4}$ brines that could have produced the salt assemblages at the Phoenix landing site on Mars, the evaporation models of Toner et al. (2015) predicted the appearance of anhydrite-gypsum, epsomitehexahydrite and hexahydrite-kieserite paragenesis at $a_{\mathrm{H}_{2} \mathrm{O}}$ values of $0.68,0.56$ and 0.52 , respectively.

In comparison to this general picture, two outcomes of our evaporation experiment regarding the formation of new phases during evolution of the brine are noticeable: the small number of precipitating minerals despite the high load and diversity of dissolved elements, and the apparent escape of several volatile components other than water. 
Relative to the evaporative enrichment factor $\left(E F=\frac{\text { final concentration }}{\text { initial concentration }}\right)$ of a perfectly conservative element such as Mg (2.37), the EF values of Ca (1.01), Si (1.72), Sr (1.97) and $\mathrm{Cl}$ (2.08) are significantly lower, indicating partial removal of these elements into phases, inferred to be gaseous $\mathrm{HCl}$ (for $\mathrm{Cl}$ ) and gypsum (for $\mathrm{Ca}$ and $\mathrm{Sr}$ ) and possibly amorphous silica (for Si) as solids. Due to its elevated concentration in the brine, the total sulphur loss associated with gypsum formation was too little to be measurable outside the analytical error.

\subsection{Hyperacid brine evolution and evaporite minerals}

The observation that gypsum and possibly amorphous silica were the only precipitating phases in the course of the experiment is grossly consistent with thermodynamic equilibrium, since the models indicate that other phases stayed far from saturation (Fig. 4b). Gypsum was the precipitating calcium-sulphate although anhydrite tended to be closer to saturation. Reported temperatures of $42-60^{\circ} \mathrm{C}$ for the transition between gypsum and anhydrite (Posnjak 1938; 1940; Hardie, 1967; Innorta et al., 1980) encompass our $60^{\circ} \mathrm{C}$ experimental temperature. Also, the transition temperature depends on overall solution chemistry and water activity (Farrah et al., 2004; Li and Demopoulos, 2006; Azimi et al., 2007). A plausible explanation for the appearance of gypsum instead of anhydrite is a kinetic control. Since the nucleation rate of anhydrite is considerably slower, gypsum might remain as a metastable phase up to $120^{\circ} \mathrm{C}$ (Ostroff, 1964; Freyer and Voigt, 2003; Azimi and Papangelakis, 2011; Ossorio et al., 2014).

In absence of unambiguous evidence for fluorine loss, which would support possible degassing of $\mathrm{SiF}_{4(\mathrm{~g})}$, we tentatively attribute the concentration decline of $\mathrm{Si}$ to formation of amorphous silica, a phase that is commonly saturated in the Kawah Ijen lake (Delmelle and Bernard, 1994; Delmelle et al., 2000). However, because the brine sample had been filtered and the experimental temperature was some $20^{\circ} \mathrm{C}$ higher than during its storage, the solution must have been undersaturated at least at the start of the experiment. Similar to gypsum, the PHREEQC models do not predict attainment of saturation for amorphous silica (Fig. 4b) but its SI value reached a maximum approximately at the time when the Si concentration decrease started (cf. Fig. 3d). Calculations based on Gunnarsson and Arnórsson (2000) suggest that $\mathrm{SiO}_{2_{a m}}$ solubility at $60^{\circ} \mathrm{C}$ would be almost three times the maximum concentration measured in the 
experiment, but the temperature equations of these authors describe the solubility in pure water, making its applicability to the hyperacid highly saline brine questionable. We speculate that nanoparticles did form under the extreme acidic conditions and eventually reached a sufficiently large size to be filtered out, since increasing ionic strength, decreasing water activity and decreasing $\mathrm{pH}$ suppress amorphous silica solubility and promote polymerization and particle flocculation rates (Marshall and Warakomski, 1980; Gorrepati et al., 2010).

In order to explore the possible stability of phases beyond the lowest water activity reached in the experiments $\left(a_{H_{2} O}=0.85\right)$, an evaporation process was simulated in PHREEQC, whereby one litre of Kawah Ijen brine with the same composition as the starting experimental sample was evaporated by removing water in 1000 steps at $60^{\circ} \mathrm{C}$. The run did not converge after the $990^{\text {th }}$ step, when $99 \%$ (985 g) of the initial water content was removed and the ionic strength of the brine reached $163 \mathrm{~m}$. The $a_{\mathrm{H}_{2} \mathrm{O}}$ values dropped from 0.95 to 0.32 . The only phases formed were hydrogen chloride $\left(a_{\mathrm{H}_{2} \mathrm{O}} \leq\right.$ $0.86)$, gypsum $\left(a_{\mathrm{H}_{2} \mathrm{O}} \leq 0.83\right)$ and elemental sulphur $\left(a_{\mathrm{H}_{2} \mathrm{O}} \leq 0.65\right)$ (Figs. 10a and 10b). At the end of the simulation szolmolnokite $\left(\mathrm{FeSO}_{4} \cdot \mathrm{H}_{2} \mathrm{O}\right)$ and rozenite $\left(\mathrm{FeSO}_{4} \cdot 4 \mathrm{H}_{2} \mathrm{O}\right)$ together with kieserite $\left(\mathrm{MgSO}_{4} \cdot \mathrm{H}_{2} \mathrm{O}\right)$ and starkeyite $\left(\mathrm{MgSO}_{4} \cdot 4 \mathrm{H}_{2} \mathrm{O}\right)$ were among the iron and magnesium sulphates that approached the highest saturation levels, but none of these salts were predicted to precipitate, even at the lowest $a_{\mathrm{H}_{2} \mathrm{O}}$ values of the simulation. The same applied for some halides as well (Figs. a, b and c; EA-4).

Considering these observations, the absence of precipitating halide and sulphate phases other than gypsum in the course of the experiment is largely in line with equilibrium modelling results. Apparently, the elevated concentrations reached by $\mathrm{Cl}$ and $\mathrm{S}_{\mathrm{T}}$ (total sulphur) promoted complexation with $\mathrm{Mg}$ and $\mathrm{Fe}$, mainly as $\mathrm{FeCl}^{+}, \mathrm{FeCl}^{2+}, \mathrm{FeSO}_{4}{ }^{0}, \mathrm{MgCl}^{+}$ and $\mathrm{MgSO}_{4}{ }^{0}$, which increased the solubilities of these cations and prevented them from precipitating as salts (Figs. 6, 11 and EA-2, EA-5). Similar arguments explain the absence of $\mathrm{Al}-, \mathrm{K}$ - or Na-bearing phases. Our experimental and theoretical findings are also consistent with field evidence, since gypsum is usually the only major sulphate found in volcanic lake settings where hyperacid brine is subjected to simple evaporation alone (e.g., Rodríguez et al. 2016b; Rodríguez and van Bergen 2017). Amorphous silica is also a common phase in these surface expressions of volcanic-hydrothermal systems, where 
its precipitation is largely governed by a drop of the brine temperature under ambient conditions.

\subsection{Hyperacid brine evolution and volatile phases}

The progressive water loss and concomitant $\mathrm{pH}$ decline not only caused an overall elemental concentration increase, but according to equation (2), it also promoted the formation of $\mathrm{HCl}_{(\mathrm{aq})}$ at the expense of $\mathrm{Cl}$. The $\mathrm{Br} / \mathrm{Cl}$ ratios increased slightly (Fig. 12) due to stronger volatilization of $\operatorname{HCl}_{(\mathrm{g})}$ than $\operatorname{HBr}_{(\mathrm{g})}$, since in aqueous solutions $\operatorname{HBr}_{(\mathrm{ac})}$ is a stronger acid than $\mathrm{HCl}_{(\mathrm{ac})}$ and thus tends to remain dissociated to a larger extent (Marcus, 1979). The model predicts that $\mathrm{Br} / \mathrm{Cl}$ ratios become even more pronounced at higher degrees of evaporation than covered by our experiment, with molar $\mathrm{Br} / \mathrm{Cl}$ ratios in the remaining solution ultimately increasing up to more than 30 times the starting value. A simultaneous increase in the $\mathrm{S}_{\mathrm{T}} / \mathrm{Cl}$ ratio further confirms the $\mathrm{HCl}_{(\mathrm{g})}$ loss (Fig. 12). Both the experimental and modelling results thus provide evidence for unequal rates of halogen volatilization from highly acidic solutions as an efficient mechanism to fractionate $\mathrm{Cl}$ from $\mathrm{Br}$, two elements that commonly show a similar hydrophilic behaviour in most terrestrial environments (Aiuppa et al., 2009).

Complexities in the partitioning behaviour of $\mathrm{Cl}$ and $\mathrm{Br}$ among co-existing brine and vapour have also been highlighted in studies of phase separation in sub seafloor hydrothermal systems. Results from field studies and autoclave experiments are not conclusive as to whether $\mathrm{Br}$ or $\mathrm{Cl}$ preferentially partitions into the low-salinity vapour phase fluids relative to the brines. Although most experiments and measurements on natural vent fluids tend to favour preferential partitioning of $\mathrm{Br}$ in the vapour phase (e.g., Von Damm et al., 2003; Foustoukos and Seyfried, 2007; Seo and Zajacz, 2016), others reported an opposite trend (e.g., Liebscher et al., 2006). Factors that may influence the partitioning behaviour include P-T conditions at which phase separation occurs, density contrast between vapour and brine, and alkali metals present in the solution (Seo and Zajacz, 2016).

\subsection{Chlorine isotope fractionation - changing mechanism during evaporation}

Theoretical equilibrium $1000 \ln \alpha_{\mathrm{HCl}_{(\mathrm{g})}-\mathrm{Cl}_{\mathrm{diss}} \text {. }}$ values at $60^{\circ} \mathrm{C}$ reported by Czarnacki and Halas (2012) are $+1.55 \%$ and $+1.69 \%$, based on data from Urey and Greiff (1935) and 
Schauble et al. (2003), respectively. Experimental results of Sharp et al. (2010) for equilibrium $\mathrm{Cl}$ isotope fractionation between $\mathrm{HCl}_{(\mathrm{g})}$ and hydrochloric acid are +1.4 to $+1.8 \%$ between 50 and $79^{\circ} \mathrm{C}$. These authors attributed the preference of the heavy $\mathrm{Cl}$ isotope for the gas phase to the differences in bond types, because the bond between $\mathrm{Cl}$ and $\mathrm{H}$ in the $\mathrm{HCl}_{(\mathrm{g})}$ molecule will be stronger than that of a solvated $\mathrm{Cl}^{-}$ion in an aqueous solution and therefore more capable to hold the heavier ${ }^{37} \mathrm{Cl}$.

Our experimental results before 500 hours are consistent with the tendency that ${ }^{37} \mathrm{Cl}$ preferentially escapes in the evaporating $\mathrm{HCl}_{(\mathrm{g})}$. However, the magnitude of fractionation is higher (average of four estimates is $+2.5 \%$, Table 7 ), although for one approach ( $\mathrm{Cl}$ mass losses based on $\mathrm{B} / \mathrm{Cl}$ ratios) the result of $+1.55 \pm 0.49 \%$ is closer to the theoretical values of Czarnacki and Halas (2012). This enhanced isotopic fractionation effect can be explained by the experimental conditions of open-system evaporation, instead of the closed-system equilibrium cases on which the previous theoretical and experimental results were based.

In contrast, the experimental results after 500 hours point to a fractionation in opposite direction, i.e. with a strong preference of light ${ }^{35} \mathrm{Cl}$ for the gas phase (average of four estimates is $-4.9 \%$, Table 4). Sharp et al. (2010) found a similar partitioning behaviour in a kinetic evaporation experiment with concentrated hydrochloric acid (11.6 M) at room temperature, which yielded a $1000 \ln \alpha_{\mathrm{HCl}_{(\mathrm{g})}-\mathrm{Cl}_{\text {diss. }}}$ value of $-4.0 \%$. They ascribed this to a kinetic effect associated with the higher translational velocity of $\mathrm{H}^{35} \mathrm{Cl}$, which will thus escape more readily from the solution.

The change in overall fractionation behaviour in the course of the evaporation experiment can be explained by individual fractionation steps during the two successive reactions needed to form gaseous $\mathrm{HCl}_{(\mathrm{g})}$ from the solution:

$$
\begin{aligned}
\mathrm{Cl}^{-}+\mathrm{H}_{3} \mathrm{O}^{+} & \Leftrightarrow \mathrm{HCl}^{0}+\mathrm{H}_{2} \mathrm{O} \\
\mathrm{HCl}^{0} & \Leftrightarrow \mathrm{HCl}_{(g)}
\end{aligned}
$$

The formation of aqueous $\mathrm{HCl}^{0}$ (reaction 10) is associated with a positive fractionation factor, and the evaporation step (reaction 11) with a negative one. Competition between these opposing effects thus determines the sign and magnitude of the overall isotopic fraction between gaseous $\mathrm{HCl}_{(\mathrm{g})}$ and total dissolved $\mathrm{Cl}$. 
According to our speciation calculations, $\mathrm{Cl}^{-}$was the dominant $\mathrm{Cl}$ species in solution before 500 hours (80.5\% of the total chlorine molality at $t=0$ hours, Fig. 13), which suggests that reaction (10) was the rate limiting step in the formation of $\mathrm{HCl}_{(\mathrm{g})}$. Apparently, the effect of the associated isotopic fractionation overwhelmed that of the subsequent evaporation step, so that the first escaping hydrogen chloride consisted mainly of $\mathrm{H}^{37} \mathrm{Cl}_{(\mathrm{g})}$. After 500 hours, $\mathrm{HCl}^{0}$ became the dominant species $(60.5 \%$ at $\mathrm{t}=1750$ hours, Fig. 12), which turned kinetic fractionation accompanying reaction (11) into the determining factor. Hence, as soon as much of the chlorine in the solution was converted into $\mathrm{HCl}^{0}$, the bonding effect became less important in fractionating the isotopes during $\mathrm{HCl}_{(\mathrm{g})}$ evaporation in comparison to the kinetic effect associated with translational velocity differences between $\mathrm{H}^{35} \mathrm{Cl}^{0}$ and $\mathrm{H}^{37} \mathrm{Cl}^{0}$. Consequently, from then on, hydrogen chloride preferentially escaped as $\mathrm{H}^{35} \mathrm{Cl}_{(\mathrm{g})}$. According to PHREEQC calculations, at $25^{\circ} \mathrm{C}$, $\mathrm{HCl}^{0}$ accounts for $63.1 \%$ of the total chlorine concentration, and $36.9 \%$ for $\mathrm{Cl}^{-}$in a concentrated hydrochloric acid solution, which implies that the kinetic evaporation experiments of Sharp et al. (2010) mainly measured the fractionation between $\mathrm{HCl}^{0}$ and $\mathrm{HCl}_{(\mathrm{g})}$ as a product of reaction (11), similar to the conditions in our experiment after 500 hours. The correspondence in sign and magnitude of the isotopic fractionation between the two experiments supports this conjecture.

Following this reasoning, the apparent fractionation of chlorine isotopes between gaseous $\mathrm{HCl}$ and total $\mathrm{Cl}$ in an aqueous solution depends on the speciation of dissolved $\mathrm{Cl}$, i.e. on the proportions of $\mathrm{Cl}^{-}$and $\mathrm{HCl}^{0}$. As the speciation calculations demonstrate, the experimental brine may also contain substantial amounts (up to 25\%) of various complexed Cl species (Fig. 12). Because fractionation factors among all these dissolved species are unknown, a rigorous quantitative approach is not feasible, so that the inferred magnitudes for the initial and final parts of the experiment should be taken as approximations for the two different fractionation regimes. Further experimental and theoretical work is needed to substantiate these findings and to clarify the underlying controls.

\subsection{Implications for $\mathrm{Cl}$ isotope signatures of volcanic crater lakes}

The $\mathrm{Cl}$ isotope signature of hydrothermal fluids that feed an active volcanic lake is initially determined by the source(s) of chlorine, commonly a shallow magma body undergoing exsolution, and potentially also by fractionation during subsequent 
subsurface rock-gas-liquid interactions in the hydrothermal system or by a mixture of chlorine from shallow reservoirs such as seawater, groundwater or evaporites (Li et al., 2015; Rodríguez et al., 2016a). Field observations revealed that gaseous $\mathrm{HCl}$ occasionally escapes from the surface of warm, highly acidic volcanic lakes (Rowe et al. 1992; Rouwet and Ohba, 2015; Rouwet et al., 2016; Rodríguez et al., 2016a), with volatilization being enhanced by increasing $\mathrm{H}_{2} \mathrm{SO}_{4}$ abundance (lowering $\mathrm{pH}$ ), water temperature or $\mathrm{Cl}^{-}$content (Truesdell et al., 1989; Capaccioni et al., 2016). Hence, any fractionation associated with evaporative $\mathrm{HCl}_{(\mathrm{g})}$ loss may have a superimposed effect on the isotope signature of the lake water body. According to our experimental results, the sign of fractionation depends on the proportions of dissolved Cl-species in the lake water, so in theory, this may become either enriched or depleted in ${ }^{37} \mathrm{Cl}$.

However, in a steady state situation with a continuous supply of hydrothermal fluid needed to sustain the volume of a warm evaporating lake (Pasternack and Varekamp, 1997), the loss of $\mathrm{HCl}_{(\mathrm{g})}$ will be small relative to the amount of dissolved chlorine in the lake reservoir, making a major isotopic shift unlikely. The restricted $\delta^{37} \mathrm{Cl}$ range between 0.0 and $+1.2 \%$ found in acid crater lakes of volcanoes in subduction settings to date (Eggenkamp, 1994; Sharp et al., 2010; Rodríguez et al., 2016a) falls within the range between -3 and $+3 \%$ reported for subduction-related volcanics (Barnes and Sharp, 2017; Liotta et al., 2017), suggesting that input signatures will generally be more important than evaporation effects in creating isotopic variations. Nevertheless, possible indications for an evaporation-induced $\mathrm{Cl}$ isotope shift come from the hyperacid crater lake of Poás volcano (Costa Rica) where long-term monitoring during almost three decades yielded $\delta^{37} \mathrm{Cl}$ between $+0.02 \pm 0.06 \%$ and $+1.15 \pm 0.09 \%$, with some of the highest values recorded during an active period when the lake volume was reduced, temperature high and $\mathrm{pH}<0$ (Rodríguez et al., 2016a). According to the fractionation mechanism inferred from our experiments, this strong acidity favoured the prevalence of $\mathrm{HCl}^{0}$ as dissolved chlorine species, which should have promoted the predominant escape of the lighter $\mathrm{Cl}$ isotope as gaseous $\mathrm{HCl}$. The evaporative $\mathrm{HCl}_{(\mathrm{g})}$ loss is also reflected in increased $\mathrm{Br} / \mathrm{Cl}$ ratios in the lake brine during the same time interval (Rodríguez et al., 2016a), in agreement with the lower volatilization rate of $\operatorname{HBr}_{(\mathrm{g})}$ under extremely acid conditions seen in our experiments.

\subsection{Implications for Mars}


The widespread existence of evaporate material across the Martian surface indicates that fluid evaporation played an important role in the geologic past of the planet (Altheide et al., 2009). Hence, the results of our experiments are potentially significant for interpretations of $\delta^{37} \mathrm{Cl}$ signatures of secondary $\mathrm{Cl}$-bearing minerals considered to have formed through evaporative processes. The hypothesis of two $\mathrm{Cl}$ reservoirs on this planet is represented by a ${ }^{37} \mathrm{Cl}$-depleted mantle from olivine-phyric shergottites $\left(\delta^{37} \mathrm{Cl}=\right.$ -3.8 to $-2.0 \%$ ) and a ${ }^{37} \mathrm{Cl}$-enriched crust from chassignites and nakhlites $\left(\delta^{37} \mathrm{Cl}\right.$ up to $+8.6 \%$ ) (Sharp et al., 2016; Williams et al., 2016). The most negative values, found in olivine-phyric shergottites, have been taken to represent the primordial bulk composition of Mars, which the planet may have acquired during accretion, whereas the positive values, measured in other Martian meteorites, are suggestive of a ${ }^{37} \mathrm{Cl}$ enriched crust, possibly due to preferential loss of ${ }^{35} \mathrm{Cl}$ into space from the surface (Sharp et al. 2016; Williams et al., 2016). However, Bellucci et al. (2017) reported an average $\delta^{37} \mathrm{Cl}$ content of $-0.6 \%$ for apatites in shergottites with no textural, major element or halogen evidence for mixing with a surface reservoir. The authors concluded that the bulk $\mathrm{Cl}$ isotope compositions of Mars and Earth are not significantly different from each other and that the mixture of surface material with a crystallizing mafic or ultramafic magma is responsible for both negative $(-5.6$ to $-0.2 \%$ ) and positive $(+1.1$ to $+2.5 \% 0)$ shifts in $\delta^{37} \mathrm{Cl}$.

Tosca and McLennan (2006) have shown that, when starting from a solution that derived its cations from rock weathering, evaporation may develop a large spectrum of different brine compositions depending on the abundance and relative proportions of $\mathrm{HCO}_{3}-\mathrm{SO}_{4}^{-2}$, and $\mathrm{Cl}^{-}$as principal anions. The authors proposed that saline mineral formation through evaporation on Mars, either proceeded in acid-sulphate dominated surficial environments or under conditions where acidity was buffered by basaltic weathering reactions and carbonates were produced. The evaporation path of the Kawah Ijen brine is more in line with the former option but is distinct in detail since the starting fluid is a hyperacid sulphate-chloride solution with an initial high load of cations due to rock dissolution. If halogen-rich brines with a similar hydrothermal origin existed on Mars (e.g., Schmidt et al., 2008; Yen et al., 2008), our findings indicate that evaporation-induced degassing of $\mathrm{HCl}$ will have either increased or decreased $\delta^{37} \mathrm{Cl}$ in the residual solutions, since sign and magnitude of fractionation seem controlled by $\mathrm{pH}$ dependent distribution of the $\mathrm{Cl}$-species. Cases of ${ }^{37} \mathrm{Cl}$ enrichment may signal a very 
strong acidity since a preferred escape of the lighter isotope presumably requires a prevalence of aqueous $\mathrm{HCl}^{0}$ over $\mathrm{Cl}^{-}$. In view of this mechanism, $\mathrm{HCl}$ degassing alone is inadequate as explanation for the elevated $\delta^{37} \mathrm{Cl}$ signatures of nahklites, since the hydrothermal fluid inferred to have infiltrated the parent rock was $\mathrm{CO}_{2}$ rich and had a circum-neutral pH (Bridges and Schwenzer, 2012; Filiberto et al., 2014). More likely, fractionation accompanying precipitation and removal of a Cl-bearing phase may have driven $\delta^{37} \mathrm{Cl}$ to the positive values. Also, if the extremely light and highly variable $\delta^{37} \mathrm{Cl}$ values (from $-51 \pm 5 \%$ o to $-1 \pm 7 \% 0$ ) measured in sedimentary rocks and sand in Gale Crater by the SAM instrument on the Curiosity Rover (Farley et al., 2016) are correct, the Cl-hosting mineral(s) could not have been precipitated from an acidic brine that had undergone simple $\mathrm{HCl}$ evaporation. Although, according to our experiments, it is conceivable that $\mathrm{HCl}$ loss could drive the residual solution to lower $\delta^{37} \mathrm{Cl}$, the fractionation factor would not be sufficient to reach the extreme negative values starting from a Martian mantle value, if Rayleigh-type fractionation is assumed. More likely, unusual low ${ }^{37} \mathrm{Cl} /{ }^{35} \mathrm{Cl}$ ratios are attributable to involvement of perchlorates, either as component in measured material or as its precursor (Farley et al., 2016; Bellucci et al., 2017). Our experiments also highlight the possibility that aqueous bromine and chlorine can become fractionated as a result of unequal evaporation rates of $\operatorname{HCl}_{(\mathrm{g})}$ and $\operatorname{HBr}_{(\mathrm{g})}$. This mechanism, together with precipitation of halogen-bearing minerals, could explain the variability of $\mathrm{Br} / \mathrm{Cl}$ ratios and frequent Br-enrichments in soils of Gusev Crater and Meridiani Planum (e.g., Gellert et al., 2006; Marion et al., 2009).

The modelled progressive reduction of water activity in our experimental liquid can be used to estimate the theoretical freezing temperature of a residual Martian brine that experienced extensive evaporation (Chevrier and Altheide, 2008; Elsenousy et al., 2015):

$$
\begin{gathered}
T_{E}=\frac{1}{\frac{1}{T_{0}}-\frac{R \ln a_{H_{2} O}}{\Delta H_{f}}} \\
\Delta H_{f}=3.34768+\frac{1.85714}{1+\exp \left(\frac{a_{\mathrm{H}_{2} \mathrm{O}}-0.53822}{0.05031}\right)}+1.855921 \cdot a_{\mathrm{H}_{2} \mathrm{O}}
\end{gathered}
$$

Where $T_{E}$ is the freezing temperature, $R$ is the ideal gas constant, $a_{H_{2} O}$ is the activity of water, $T_{0}=273.15 \mathrm{~K}$; and $\Delta H_{f}$ is the enthalpy of fusion. 
If similar hyperacid brines as that of Kawah Ijen would have been created on Mars (e.g., as a result of interaction of magmatic volatiles and ice, combined with intense waterrock interaction), the lowest $a_{\mathrm{H}_{2} \mathrm{O}}$ value of 0.85 reached in our simulation predicts freezing temperatures down to $183 \mathrm{~K}\left(-90.15^{\circ} \mathrm{C}\right)$. This is close to the freezing point for the acids of $\mathrm{Cl}^{-}$and $\mathrm{SO}_{4}{ }^{2-}$ (Clark and Van Hart, 1981), which are among the strongest freezing point depressors. Taking the yearly average temperature of $240 \mathrm{~K}\left(-33.15^{\circ} \mathrm{C}\right)$ on Mars' surface into account (Mellon et al., 2004), the stability of liquid water on the planet would thus be significantly enhanced by the existence of compositionally equivalent hyperacid brines. A final corollary is that the extreme chemistry of such evaporating brines, notably the combination of very low $\mathrm{pH}$, low water activity and high salinity, has a negative effect on Martian habitability (Fox-Powell et al., 2016).

\section{SUMMARY AND CONCLUSIONS}

A 73-days long experiment on crater lake water from Kawah Ijen volcano (Indonesia) was carried out to study the chemical evolution of highly saline, hyperacid sulphatechloride brine during extended evaporation, with special attention to chlorine isotope fractionation associated with the escape of gaseous $\mathrm{HCl}$. Up to 58\% evaporative water loss from the brine (starting pH ca. 0.1, TDS ca. $100 \mathrm{mg} / \mathrm{kg}$ ) was accompanied by increasing contents of dissolved rock-forming elements, sulphur and halogens. Despite the high load and diversity of solutes, newly formed solid phases were restricted to Srbearing gypsum and possibly amorphous silica. The limited capability of producing evaporite minerals relative to that of seawater and other brine types apparently signals strongly enhanced metal solubilities due to complexation with abundantly available $\mathrm{HSO}_{4}^{-}, \mathrm{Cl}^{-}$and $\mathrm{F}^{-}$.

Continuous loss of $\mathrm{HCl}_{(\mathrm{g})}$ throughout the experiment permitted deriving quantitative insight into $\mathrm{Cl}$-isotope fractionation between aqueous and gaseous chlorine. Monitoring the residual solution revealed a marked change in sign and magnitude of fractionation when evaporation proceeded. In the first three weeks of the experiment, the evaporating $\mathrm{HCl}_{(\mathrm{g})}$ was isotopically heavier than the chlorine remaining in solution. Assuming Rayleigh-type behaviour, the calculated fractionation factor $\left(1000 \ln \alpha_{\mathrm{HCl}_{\mathrm{g}}-\mathrm{Cl}_{\mathrm{diss}} \text {. }}\right.$ ) was from $+1.55 \pm 0.49 \%$ o to $+3.37 \pm 1.10 \%$, depending on the method for determining the $\mathrm{Cl}$ losses from the brine. In contrast, the evaporating $\mathrm{HCl}_{(\mathrm{g})}$ became isotopically 
lighter in the subsequent interval, with a corresponding fractionation factor between $5.67 \pm 0.17 \%$ and $-3.97 \pm 0.08 \%$, more in line with existing experimental data (Sharp et al., 2010). The change in behaviour coincided with a transition from $\mathrm{Cl}^{-}$to $\mathrm{HCl}^{0}$ as the dominant chlorine species in the solution when $\mathrm{pH}$ had dropped below ca. -0.2. It is inferred that the distribution of dissolved $\mathrm{Cl}$ species exerts a strong control on sign and magnitude of $\mathrm{Cl}$ isotope fractionation during $\mathrm{HCl}_{(\mathrm{g})}$ evaporation from an acid brine. Because evidence for $\operatorname{HBr}_{(\mathrm{g})}$ loss is tenuous and the escape of $\mathrm{HCl}_{(\mathrm{g})}$ is clearly more efficient, selective evaporation can also be an effective mechanism to fractionate $\mathrm{Cl}$ from $\mathrm{Br}$ and other solutes in acidic sulphate-chloride brines.

In most cases, surface evaporation of $\mathrm{HCl}_{(\mathrm{g})}$ will have little effect on the $\mathrm{Cl}$ isotope compositions or $\mathrm{Cl} / \mathrm{Br}$ ratios of sizable active volcanic lakes due to the large mass of dissolved chlorine compared to the evaporated fraction and the continuous supply of magmatic volatiles that usually mark these reservoirs. Detectible fractionation effects in hyperacid lakes may be limited to periods of enhanced evaporation and volume reduction.

The results of this work may provide new clues on the origin of $\mathrm{Cl}$ isotope signatures and $\mathrm{Cl} / \mathrm{Br}$ variability in Martian soils and minerals. If evaporation of highly acidic fluids played a role, preferential loss of $\mathrm{HCl}_{(\mathrm{g})}$ would yield a relative enrichment of $\mathrm{Br}$ and a shift in Cl-isotope composition either in positive or in negative direction, depending on the speciation of aqueous chlorine and thus on $\mathrm{pH}$. It is conceivable that such effects are preserved in halogen-bearing salts and other solid residues of evaporation. Finally, the (former) presence of hyperacid sulphate-chloride brines as studied here would extend the stability of liquid water on the planet's surface to extremely low temperatures.

\section{ACKNOWLEDGMENTS}

All laboratory analyses were performed with the instrumental facilities of the Department of Earth Sciences, Utrecht University. We are grateful to Arnold van Dijk for carrying out the mass spectrometer measurements, and to Helen de Waard, Ton Zalm and Dineke van de Meent for help with experiments, ICP-OES and IC analyses, respectively. Our appreciation also goes to Helen King for expert support with Raman spectroscopy and SEM techniques, and to Sergei Matveev for the skilful EPMA work. The 
manuscript benefited from the valuable comments of the reviewers. Funding for this research was provided by NWO (Netherlands Organization for Scientific Research), project ALW-GO-PL/10-03. H.G.M. Eggenkamp has received funding from the European Union's Horizon 2020 research and innovation programme as Individual Fellow under the Marie Skłodowska-Curie Actions (grant agreement $\mathrm{N}^{\circ} 702001$, BRISOACTIONS). This is IPGP contribution 3884.

\section{REFERENCES}

Aiuppa A., Baker D. R. and Webster J. D. 2009. Halogens in volcanic systems. Chem. Geol. 263, 1-18.

Altheide T., Chevrier V., Nicholson C. and Denson J., 2009. Experimental investigation of the stability and evaporation of sulfate and chloride brines on Mars. EPSL 282, 69-78.

Azimi G. and Papangelakis V.G., 2011. Mechanism and kinetics of gypsum-anhydrite transformations in aqueous electrolyte solutions. Hydrometallurgy 108, 122-129.

Azimi G., Papangelakis V.G., Dutrizac J.E., 2007. Modelling of calcium sulphate solubility in concentrated multi-component sulphate solutions. Fluid Phase Equilib. 260, 300-315.

Barnes J.D. and Sharp Z.D., 2017. Chlorine isotope geochemistry. In: Non-Traditional Stable Isotopes (eds. F.Z. Teng, J. Watkins and N. Dauphas). Rev. Min. Geochem. 82, 345-378.

Bell J., McSween H., Crisp J., Morris R., Murchie S., Bridges N., Johnson J., Britt D., Golombek M., Moore H., Ghosh A., Bishop J., Anderson R., Bruckner J., Economou T., Greenwood J., Gunnlaugsson H., Hargraves R., Hviid S., Knudsen J., Madsen M., Reid R., Rieder R. and Soderblom L., 2000. Mineralogic and compositional properties of Martian soil and dust: Results from Mars Pathfinder. J Geophysical Res. 105, 1721-1755.

Bellucci J.J., Whitehouse M.J., John T., Nemchin A.A., Snape J.F., Bland P.A. and Benedix G.K., 2017. Halogen and $\mathrm{Cl}$ isotopic systematics in Martian phosphates: Implications for the $\mathrm{Cl}$ cycle and surface halogen reservoirs on Mars. Earth Planet. Sci. Lett. 458, 192-202.

Brass G.W., 1980. Stability of brines on Mars. Icarus 42, 20-28.

Bridges J.C. and Schwenzer S.P., 2012. The nakhlite hydrothermal brine on Mars. Earth Planet. Sci. Lett. 359-360, 117-123.

Capaccioni B., Rouwet D. and Tassi F., 2016. HCl degassing from extremely acidic crater lakes: preliminary results from experimental determinations and implications for geochemical monitoring. In: Geochemistry and Geophysics of Active Volcanic Lakes. (eds. T. Ohba, B. Capaccioni and C. Caudron) Geological Society of London Special Publications, 437, http://doi.org/10.1144/SP437.11.

Caudron C., Campion R., Rouwet D., Lecocq T., Capaccioni B., Syahbana D., Supergun, Purwanto B.H. and Bernard A., 2017. Stratification at the Earth's largest hyperacidic lake and its consequences. Earth Planet. Sci. Lett. 459, 28-35.

Chevrier V.F. and Altheide T.S., 2008. Low temperature aqueous ferric sulfate solutions on the surface of Mars. Geophys. Res. Lett 35, L22101, doi: 10.1029/2008GL035489.

Christenson B.W. and Wood C.P., 1993. Evolution of a vent-hosted system beneath Ruapehu Crater Lake, New Zealand. Bull. Volcanol. 55, 547-565.

Clark B.C. and Van Hart D.C., 1981. The salts of Mars. Icarus 45, 370-378.

Clark B.C., Morris R.V., McLennan S.M., Gellert R., Jolliff B., Knoll A.H., Squyres S.W., Lowenstein T.K., Ming D.W., Tosca N.J., Yen A., Christensen P.R., Gorevan S., Bruckner J., Calvin W., Dreibus G., Farrand W., Klingelhoefer G., Waenke H., Zipfel J., Bell J. F., Grotzinger J., McSween H.Y. and Rieder R., 2005. Chemistry and mineralogy of outcrops at Meridiani Planum. Earth Planet. Sci. Lett. 240, 73-94. 
Czarnacki M. and Halas S., 2012. Isotope fractionation in aqua-gas systems: $\mathrm{Cl}_{2}-\mathrm{HCl}-\mathrm{Cl}, \mathrm{Br}_{2}-$ $\mathrm{HBr}-\mathrm{Br}^{-}$and $\mathrm{H}_{2} \mathrm{~S}-\mathrm{S}^{2-}$. Isot. Environ. Health Stud. 48, 55-64.

Delmelle P. and Bernard A., 1994. Geochemistry, mineralogy and chemical modelig of the acid crater lake of Kawah-Ijen Volcano, Indonesia. Geochim. Cosmochim. Acta 58, 24452460.

Delmelle P., Bernard A., Kusakabe M., Fischer T.P. and Takano B., 2000. Geochemistry of the magmatic-hydrothermal system of Kawah Ijen volcano, East Java, Indonesia. $\mathrm{J}$. Volcanol. Geotherm. Res. 97, 31-53.

Eggenkamp H.G.M., 1994. The Geochemistry of chlorine isotopes. PhD. thesis, Utrecht University, $150 \mathrm{p}$.

Elsenousy A., Hanley J. and Chevrier V.F., 2015. Effect of evaporation and freezing on the salt paragenesis and habitability of brines at the Phoenix landing site. Earth Planet. Sci. Lett. 421, 39-46.

Farrah H.E., Lawrance G.A., Wanless E.J., 2004. Gypsum-anhydrite transformation in hot acidic manganese sulphate solution. A comparative kinetic study employing several analytical methods. Hydrometallurgy 75, 91-98.

Farley K.A., Martin P., Archer Jr. P.D., Atreya S.K., Conrad P.G., Eigenbrode J.L., Fairén A.G., Franz H.B., Freissinet C., Glavin D.P., Mahaffy P.R., Malespín C., Ming D.W., NavarroGonzález R. and Sutter B., 2016. Light and variable ${ }^{37} \mathrm{Cl} /{ }^{35} \mathrm{Cl}$ ratios in rocks from Gale Crater, Mars: Possible signature of perchlorate. Earth Planet. Sci. Lett. 438, 14-24.

Filiberto J., Treiman A.H., Giesting P.A., Goodrich C.A. and Gross J., 2014. High-temperature chlorine-rich fluid in the Martian crust: A precursor to habitability. Earth Planet. Sci. Lett. 401, 110-115.

Foustoukus D. and Seyfried W.E. Jr, 2007. Fluid phase separation processes in hydrothermal systems. In: Fluid-fluid interactions (eds. A. Liebscher and C.A Heinrich), Rev. Min. Geochem. 65, 213-233.

Fox-Powell M.G., Hallsworth J.E., Cousins C.R., Cockell C.S., 2016. Ionic strength is a barrier to the habitability of Mars. Astrobiology 16, 427-442.

Freyer D., Voigt W., 2003. Invited review, crystallization and phase stability of $\mathrm{CaSO}_{4}$ and $\mathrm{CaSO}_{4}$-based salts. Monatsh. Chem. 134, 693-719.

Gamazo P., Bea S.A., Saaltink M.W., Carrera J. and Ayora C., 2011. Modeling the interaction between evaporation and chemical composition in a natural saline system. J. Hydrol. 401, 154-164.

Gellert R., Rieder R., Anderson R., Bruckner J., Clark B., Dreibus G., Economou T., Klingelhofer G., Lugmair G., Ming D., Squyres S., d'Uston C., Wanke H., Yen A. and Zipfel J., 2004. Chemistry of rocks and soils in Gusev crater from the Alpha Particle X-ray Spectrometer. Science 305, 829-832.

Gellert R., Rieder R., Bruckner J., Clark B., Dreibus G., Klingelhofer G., Lugmair G., Ming D., Wanke H., Yen A., Zipfel J. and Squyres S., 2006. Alpha particle X-ray spectrometer (APXS): Results from Gusev crater and calibration report. J. Geophys. Res. 111, E02S05.

Giggenbach W. F., 1975. Variations in the carbon, sulfur and chlorine contents of volcanic gas discharges from White Island, New Zealand. Bull. Volcanol. 39, 15-27.

Giggenbach W.F., 1987. Redox processes governing the chemistry of fumarolic gas discharges from White Island, New Zealand. Appl. Geochem. 2, 143-161.

Gorrepati E.A., Wongthahan P., Raha S., and Fogler H.S., 2010. Silica precipitation in acid solutions: mechanism, pH effect and salt effect. Langmuir 26, 10467-10474.

Gunnarsson I. and Arnórsson S., 2000. Amorphous silica solubility and the thermodynamic properties of $\mathrm{H}_{4} \mathrm{SiO}^{0}{ }_{4}$ in the range of $0^{\circ}$ to $350^{\circ} \mathrm{C}$ at $\mathrm{P}_{\text {sat. Geochim. Cosmochim. Acta 64, }}$, 2295-2307.

Hardie L.A., 1967. The gypsum-anhydrite equilibrium at one atmosphere. Am. Mineral. 52, 171-200.

Haskin L., Wang A., Jolliff B., McSween H., Clark B., Des Marais D., McLennan S., Tosca N., Hurowitz J., Farmer J., Yen A., Squyres S., Arvidson R., Klingelhofer G., Schroder C., de Souza P., Ming D., Gellert R., Zipfel J., Bruckner J., Bell J., Herkenhoff K., Christensen P., 
Ruff S., Blaney D., Gorevan S., Cabrol N., Crumpler L., Grant J. and Soderblom L., 2005. Water alteration of rocks and soils on Mars at the Spirit rover site in Gusev crater. Nature 436, 66-69.

Ichikuni M. and Musha S., 1978. Partition of strontium between gypsum and solution. Chem. Geol. 21, 359-363.

Innorta G., Rabbi E. and L. Tomadin, 1980. The gypsum-anhydrite equilibrium by solubility measurements. Geochim. Cosmochim. Acta 44, 1931-1936.

Johnson K.S. and Pytkowicz R.M., 1978. Ion association of the $\mathrm{Cl}^{-}$with $\mathrm{H}^{+}, \mathrm{Na}^{+}, \mathrm{K}^{+}, \mathrm{Ca}^{2+}$ and $\mathrm{Mg}^{2+}$ in aqueous solutions at $25^{\circ} \mathrm{C}$. Am. J. Sci. 278, 1428-1447.

Kaufmann R.S., 1984. Chlorine in groundwater: stable isotope distribution. PhD. thesis, University of Arizona, $137 \mathrm{p}$.

Kempter K.A. and Rowe G.L., 2000. Leakage of active crater lake brine through the north flank at Rincón de la Vieja volcano, northwest Costa Rica, and implications for crater collapse. J. Volcanol. Geot. Res. 97, 143-159.

Knauth L.P. and Burt D.M., 2002. Eutectic Brines on Mars: Origin and Possible Relation to Young Seepage Features. Icarus 158, 267-271.

Kushnir J., 1980. The coprecipitation of strontium, magnesium, sodium, potassium and chloride ions with gypsum. An experimental study. Geochim. Cosmochim. Acta 44, 1471-1482.

Li Z., Demopoulos G.P., 2006. Model-based construction of calcium sulphate phase transition diagrams in the $\mathrm{HCl}-\mathrm{CaCl}_{2}-\mathrm{H}_{2} \mathrm{O}$ system between 0 and $100{ }^{\circ} \mathrm{C}$. Ind. Eng. Chem. Res. 45, 4517-4524.

Li L., Boniface M., Aubaud C., Crispi O., Déssert C. and Agrinier P., 2015. Chlorine isotopes of thermal springs in arc volcanoes for tracing shallow magmatic activity. Earth Planet. Sci. Lett. 413, $101-110$.

Liebscher A., Lüders V., Heinrich C. and Schettler, 2006. Br/Cl signature of hydrothermal fluids: liquid-vapor of bromine revised. Geofluids 6, 113-121.

Liotta M., Rizzo A.L., Barnes J.D., D'Auria L., Martelli, M., Bobrowski, N. Wittmer J., 2017. Chlorine isotope composition of volcanic rocks and gases at Stromboli volcano (Aeolian Islands, Italy): Inferences on magmatic degassing prior to 2014 eruption. J. Volcanol. Geot. Res. 336, 168-178.

Marcus, Y., 1979. Ionic dissociation of aqueous hydrobromic acid. Part 1.-Estimate from vapour pressure and activity coefficient data. J. Chem. Soc., Faraday Trans. 1, 75, 17151727.

Marshall W.L. and Warakomski J.M., 1980. Amorphous silica solubilities II. Effect of aqueous salt solutions at $25^{\circ} \mathrm{C}$. Geochim. Cosmochim. Acta 44, 915-924.

Mellon M.T., Feldman W.C. and Prettyman T.H., 2004. The presence and stability of ground ice in the southern hemisphere of Mars. Icarus 169, 324-340.

Nordstrom D., Alpers C., Ptacek C. and Blowes D., 2000. Negative pH and extremely acidic mine waters from Iron Mountain, California. Environ. Sci. Technol. 34, 254-258.

Ossorio M., van Driessche A.E.S., Pérez P., García-Ruiz J.M., 2014. The gypsum-anhydrite paradox revised. Chem. Geol. 386, 16-21.

Ostroff A.G., 1964. Conversion of gypsum to anhydrite in aqueous salt solutions. Geochim. Cosmochim. Acta 28, 1363-1372.

Parkhurst D.L. and Appelo C.A.J., 1999. User's guide to PHREEQC (Version 2), A computer program for speciation, batch-reaction, one-dimensional transport, and inverse geochemical calculations. USGS Report 99-4259, 312 p.

Pasternack G.B. and Varekamp J.C., 1997. Volcanic lake systematics 1. Physical constraints. Bull. Volcanol. 58, 528-538.

Pitzer K.S. and Mayorga G., 1973. Thermodynamics of electrolytes II. Activity and osmotic coefficients for strong electrolytes with one or both ions univalent. J. Phys. Chem. 77, 2300-2308.

Posnjak E., 1938. The system, $\mathrm{CaSO}_{4}-\mathrm{H}_{2}$ O. Am. J. Sci. 35A, 247-272.

Posnjak E., 1940. Deposition of calcium sulphate from seawater. Am. J. Sci. 238, 559-568. 
Rodríguez A. and van Bergen M.J., 2015. Volcanic hydrothermal systems as potential analogues of Martian sulphate-rich terrains. Nederlands Journal of Geosciences http://dx.doi.org/10.1017/njg.2015.12.

Rodríguez A. and van Bergen M.J., 2017. Superficial alteration mineralogy in active volcanic systems: An example of Poás volcano, Costa Rica. J. Volcanol. Geotherm. Res. https://doi.org/10.1016/j.jvolgeores.2017.04.006.

Rodríguez A., Eggenkamp H.G.M., Martínez-Cruz M. and van Bergen M.J., 2016a. Chlorine isotope and $\mathrm{Cl}-\mathrm{Br}$ fractionation in fluids of Poás volcano (Costa Rica): Insight into an active volcanic-hydrothermal system. J. Volcanol. Geotherm. Res. 325, 70-85.

Rodríguez A., Varekamp J.C., van Bergen M.J., Kading T.J., Oonk P.B., Gammons C.H. and Gilmore M., 2016b. Acid rivers and lakes at Caviahue-Copahue volcano as potential terrestrial analogues for aqueous paleo-environments on Mars. In: Copahue volcano. (eds.) F. Tassi, O. Vaselli and A. Caselli. Springer, pp. 141-172.

Rouwet D. and Ohba T., 2015. Isotope fractionation and $\mathrm{HCl}$ partitioning during evaporative degassing from active lakes. In: Volcanic Lakes. (eds. D. Rouwet, BW Christenson, F. Tassi and J. Vandemeulebrouck). Springer, pp. 179-200.

Rouwet D., Tassi F., Mora-Amador R., Sandri L. and Chiarini V., 2014. Past, present and future of volcanic lake monitoring. J. Volcanol. Geotherm. Res. 272, 78-97.

Rouwet D., Mora-Amador R., Ramírez-Umaña C.J., González G. and Inguaggiato S., 2016. Dynamic fluid recycling at Laguna Caliente (Poás, Costa Rica) before and during the 2006-ongoing phreatic eruption cycle (2005-10). In: Geochemistry and Geophysics of Active Volcanic Lakes. (eds. T. Ohba, B. Capaccioni and C. Caudron) Geological Society of London Special Publications, 437, http://doi.org/10.1144/SP437.11.

Rowe G.L., Brantley S.L., Fernández M., Fernández J.F., Borgia A. and Barquero J., 1992. Fluidvolcano interaction in an active stratovolcano: the crater lake system of Poás volcano, Costa Rica. J. Volcanol. Geotherm. Res. 49, 23-51.

Schauble E.A., Rossman G.R. and Taylor Jr, H.P., 2003. Theoretical estimates of equilibrium chlorine-isotope fractionations. Geochim. Cosmochim. Acta 67, 3267-3281.

Seo J.H. and Zajacz Z., 2016. Fractionation of $\mathrm{Cl} / \mathrm{Br}$ during fluid phase separation in magmatic-hydrothermal fluids. Geochim. Cosmochim. Acta 183, 125-137.

Sharp Z.D., Barnes J.D., Fischer T. P. and Halick M., 2010. An experimental determination of chlorine isotope fractionation in acid systems and applications to volcanic fumaroles. Geochim. Cosmochim. Acta 74, 264-273.

Sharp Z.D., Williams J., Shearer C., Agee C. and McKeegan K., 2016. The chlorine isotope composition of Martian meteorites 2. Implications for the early solar system and the formation of Mars. Meteoritics \& Planetary Science 51, 2111-2126.

Schmidt M.E., Ruff S.W., McCoy T.J., Farrand W.H., Johnson J.R., Gellert R., Ming D.W., Morris R.V., Cabrol N., Lewis K.W. and Schroeder C., 2008. Hydrothermal origin of halogens at Home Plate, Gusev Crater. J. Geophys. Res. 113, E06S12.

Toner J.D., Catling D.C. and Light B., 2015. Modeling salt precipitation from brines on Mars: Evaporation versus freezing origin for soil salts. Icarus 250, 451-461.

Tosca N.J. and McLennan S.M., 2006. Chemical divides and evaporite assemblages on Mars. Earth Planet. Sci. Lett. 241, 21-31.

Tosca N.J. and McLennan S.M., 2009. Experimental constraints on the evaporation of partially oxidized acid-sulfate waters at the Martian surface. Geochim. Cosmochim. Acta 73, 1205-1222.

Truesdell A.H., Haizlip J.R., Ármannsson H. and D'Amore F., 1989. Origin and transport of chloride in superheated geothermal steam. Geothermics 18, 295-304.

Urey H.C. and Greiff L.J., 1935. Isotopic exchange equilibria. J. Amer. Chem. Soc. 54, 3211-327.

Van Hinsberg V., Berlo K., van Bergen M. and Williams-Jones A., 2010. Extreme alteration by hyperacidic brines at Kawah Ijen volcano, East Java, Indonesia I. Textural and mineralogical imprint. J. Volcanol. Geotherm. Res. 198, 253-263.

Varekamp J.C., Pasternack G.B. and Rowe G.L., 2000. Volcanic lake systematics II. Chemical constraints. J. Volcanol. Geotherm. Res. 97, 161-179.Williams J.T., Shearer C.K., Sharp 
Z.D., Burger P.V., McCubbin F.M., Santos A.R., Agee C.B. and McKeegan K.D., 2016. The chlorine isotopic composition of Martian meteorites 1: Chlorine isotope composition of Martian mantle and crustal reservoirs and their interactions. Meteoritics \& Planetary Science, doi: 10.1111/maps.12647.

Von Damm K.L., Lilley M.D., Shanks W.C. III, Brockington M., Bray A.M., O'Grady K.M., Olson E., Graham A., Proskurowski G., and the SouEPR Science Party, 2003. Extraordinary phase separation and segregation in vent fluids from the southern East Pacific Rise. Earth Planet. Sci. Lett. 206, 365-378.

Williams J.T., Shearer C.K., Sharp Z.D., Burger P.V., McCubbin F.M., Santos A.R., Agee C.B. and McKeegan, 2016. The chlorine isotopic composition of Martian meteorites 1: Chlorine isotope composition of Martian mantle and crustal reservoirs and their interactions. Meteoritics \& Planetary Science 51, 2092-2110.

Yen A.S., Morris R.V., Clark B.C., Gellert R., Knudson A.T., Squyres S., Mittlefehldt D.W, Ming D.W., Arvidson R., McCoy T., Schmidt M., Hurowitz J., Li R.9 and Johnson J.R., 2008. Hydrothermal processes at Gusev Crater: An evaluation of Paso Robles class soils. J. Geophys. Res. 113, E06S10, doi: 10.1029/2007JE002978.

Zolotov M.Y. and Mironenko M.V., 2007. Timing of acid weathering on Mars: A kineticthermodynamic assessment. J. Geophys. Res. 112, E07006.

\section{FIGURE CAPTIONS}

Figure 1. Experimental setup. Twenty-six plastic Greiner® tubes, each containing approximately $50 \mathrm{ml}$ of brine, were partially submerged in a water bath at $60^{\circ} \mathrm{C}$. The solutions were allowed to evaporate in air. Sampling was performed after a pre-set time interval when two tubes were removed and processed separately for analysis.

Figure 2. Time series of (a) evaporation loss (wt. \%), (b) evaporation rate (g/h/dm²) and (c) pH recorded during the experiment on the Kawah Ijen hyperacid brine. The error bars are smaller than the size of the symbols.

Figure 3. Element/Mg molar ratios recorded in the course of progressive evaporation for: (a) $\mathrm{Cl}$, $\mathrm{S}_{\mathrm{T}}$; (b) F, 10xBr, B; (c) Ca, Sr; (d) Al, Si; (e) Na, Fe; (f) K, Ti. Horizontal trends point to conservative behaviour of most elements, whereas declining ratios indicate loss of $\mathrm{Cl}, \mathrm{Ca}, \mathrm{Sr}$ and $\mathrm{Si}$ through separation of gaseous $(\mathrm{HCl})$ and solid (gypsum and possibly amorphous silica) phases. Note that the Y-axis scales are variable.

Figure 4. Time series trends for (a) fugacities of selected gaseous compounds and (b) saturation indices of selected minerals, calculated for the evaporating brine. Similar graphs for halides and sulphates with lower SI values are given in the Supplementary Electronic Annex EA-1.

Figure 5. (a) Raman spectra of gypsum precipitated in the course of the experiment. Reference spectra for anhydrite (R040012) and gypsum (R040029) are from the RRUFF database (www.rruff.info). (b) SEM image of gypsum crystals.

Figure 6. Time series of calculated activities (PHREEQC) for the main aqueous species of S(VI), $\mathrm{Cl}$ and $\mathrm{Br}$ in the residual evaporating brine. Similar graphs for metal-bearing species are given in the Supplementary Electronic Annex EA-2.

Figure 7. Evolution of $\delta^{37} \mathrm{Cl}$ in the residual hyperacid brine in the course of progressive evaporation at $\mathrm{T}=60^{\circ} \mathrm{C}$. 


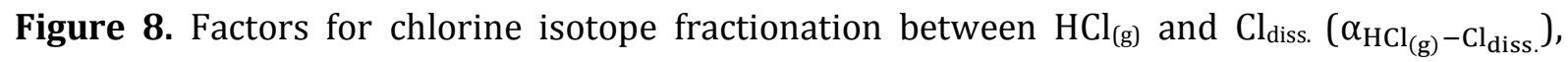
assuming Rayleigh distillation. Mass-losses of $\mathrm{Cl}$ ( $F$ values) based on: (a) $\mathrm{Cl}$ concentrations and water losses, (b) $\mathrm{Cl} / \mathrm{B}$ ratios, (c) $\mathrm{Cl} / \mathrm{Fe}$ ratios, and (d) $\mathrm{Cl} / \mathrm{Mg}$ ratios. Note the significant change in $\alpha$ value after approximately 500 hours of evaporation.

Figure 9. Measured $\delta^{37} \mathrm{Cl}$ for dissolved $\mathrm{Cl}\left(\mathrm{Cl}_{\mathrm{diss}}\right)$ and calculated $\delta^{37} \mathrm{Cl}$ for gaseous $\mathrm{Cl}\left(\mathrm{HCl}_{(\mathrm{g})}\right)$, based on (a) $\mathrm{Cl}$ mass loss, (b) $\mathrm{Cl} / \mathrm{B}$ ratios, (c) $\mathrm{Cl} / \mathrm{Fe}$ ratios, and (d) $\mathrm{Cl} / \mathrm{Mg}$ ratios. Note the significant change in $\delta^{37} \mathrm{Cl}$ after approximately 500 hours of evaporation.

Figure 10. Predicted amounts of secondary phases formed during progressive evaporation, based on PHREEQC simulation $\left(\mathrm{T}=60^{\circ} \mathrm{C}\right.$ ), as a function of (a) $\mathrm{H}_{2} \mathrm{O}$ loss (wt. \%) and (b) water activity $\left(a_{\mathrm{H}_{2} \mathrm{O}}\right)$.

Figure 11. Activities of the main species of $\mathrm{S}(\mathrm{VI}), \mathrm{Cl}$ and $\mathrm{Br}$ according to simulated evaporation (PHREEQC) of the hyperacid brine at $\mathrm{T}=60^{\circ} \mathrm{C}$. Note that curves for the activities of $\mathrm{HCl}^{\circ}$ and $\mathrm{Cl}^{-}$ cross at high degrees of water loss. Similar graphs for activities of the main metal species are given in Supplementary Electronic Annex EA-5.

Figure 12. $\mathrm{Br} / \mathrm{Cl}$ and $\mathrm{S}_{\mathrm{T}} / \mathrm{Cl}$ molar ratios recorded throughout the evaporation experiment. Increasing trends are consistent with loss of gaseous $\mathrm{HCl}$.

Figure 13. Calculated distributions of dissolved $\mathrm{Cl}$ species in the course of the evaporation experiment on the hyperacid brine, expressed as percentage of the total $\mathrm{Cl}$ molality. Note that after 500 hours $\mathrm{HCl}^{0}$ becomes more abundant than $\mathrm{Cl}^{-}$.

\section{TABLE CAPTIONS}

Table 1. Recorded data for mass loss, $\mathrm{pH}$, conductivity and evaporation rate during experimental evaporation of the hyperacid Kawah Ijen brine.

Table 2. Compositional changes in the hyperacid Kawah Ijen brine during experimental evaporation.

Table 3. Chlorine isotope evolution during experimental evaporation of the hyperacid Kawah Ijen brine, inferred from mass loss of the solution, $\delta^{37} \mathrm{Cl}$ of dissolved $\mathrm{Cl}$ and inferred $\mathrm{HCl}_{(\mathrm{g})}$ loss. Calculations of $F$ values (fractions of $\mathrm{Cl}$ remaining in solution) based on differences between measured and calculated $\mathrm{Cl}$ concentrations, combined with water-vapour losses (see Table 1). $\delta^{37} \mathrm{Cl}_{\mathrm{HCl}}$ (g) values obtained from calculated fractionation factors, assuming Rayleigh fractionation (see Figs. 8 and 9). The reported $1000 \ln \alpha_{\mathrm{HCl}_{(\mathrm{g})}-\mathrm{Cl}_{\mathrm{diss}} .}$ (\%) values assume a stepwise change in fractionation behaviour and are valid for the 0-500 hours and 500-1750 hours interval, respectively.

Table 4. Summary of chlorine isotope fractionation factors obtained from the evaporation experiments at $\mathrm{T}=60^{\circ} \mathrm{C}$, based on Rayleigh fractionation and different approaches for calculating $F$ factors (see Figs. 8 and 9, Table 3 and EA-3).

\section{SUPPLEMENTARY ELECTRONIC ANNEX CAPTIONS}

EA-1. Saturation indices of (a) halides, (b) $\mathrm{Fe}^{2+-s u l p h a t e s}$ and (c) Mg-sulphates during the evaporation experiment. 
EA-2. Time series of calculated activities (PHREEQC) of the main aqueous species of (a) Al, (b) $\mathrm{Fe}(\mathrm{II}),(\mathrm{d}) \mathrm{Fe}(\mathrm{III}),(\mathrm{e}) \mathrm{Mg}$, (f) $\mathrm{Ca}$, (g) K, (h) Na and (i) Sr. Note that the Y-axis scales are variable.

EA-3. Same as Table 3 but with $F$ values calculated from $\mathrm{Cl} / \mathrm{B}$ ratios assuming that $\mathrm{B}$ is perfectly

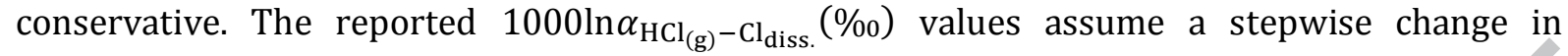
fractionation behaviour and are valid for the 0-500 hours and 500-1750 hours interval, respectively. Additionally, $F$ values are calculated from $\mathrm{Cl} / \mathrm{Fe}$ and $\mathrm{Cl} / \mathrm{Mg}$ ratios assuming that both Fe and Mg are conservative.

EA-4. Calculated changes in the saturation indices (PHREEQC) of: (a) hydrous iron (II) sulphates, (b) hydrous magnesium sulphates and (c) halides during progressive evaporation of the hyperacid brine at $\mathrm{T}=60^{\circ} \mathrm{C}$.

EA-5. Activities of the main species of (a) Al, (b) Fe(II), (b) Fe(III), (d) $\mathrm{Mg}$, (d) Ca, (f) $\mathrm{K}$, (g) $\mathrm{Na}$ and (h) Sr according to simulated evaporation (PHREEQC) of the hyperacid brine at $\mathrm{T}=60^{\circ} \mathrm{C}$. Note that the Y-axis scales are variable. 


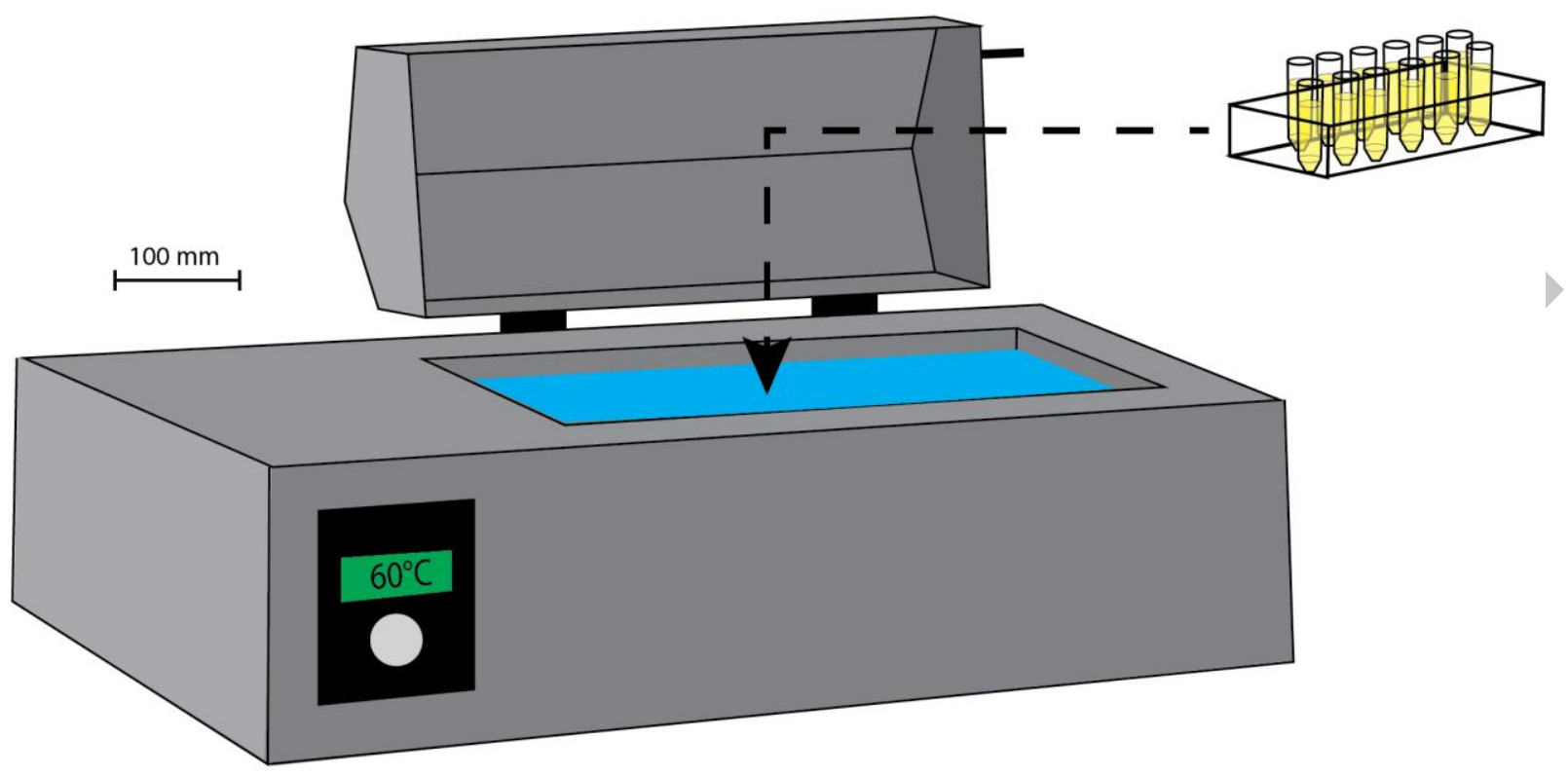




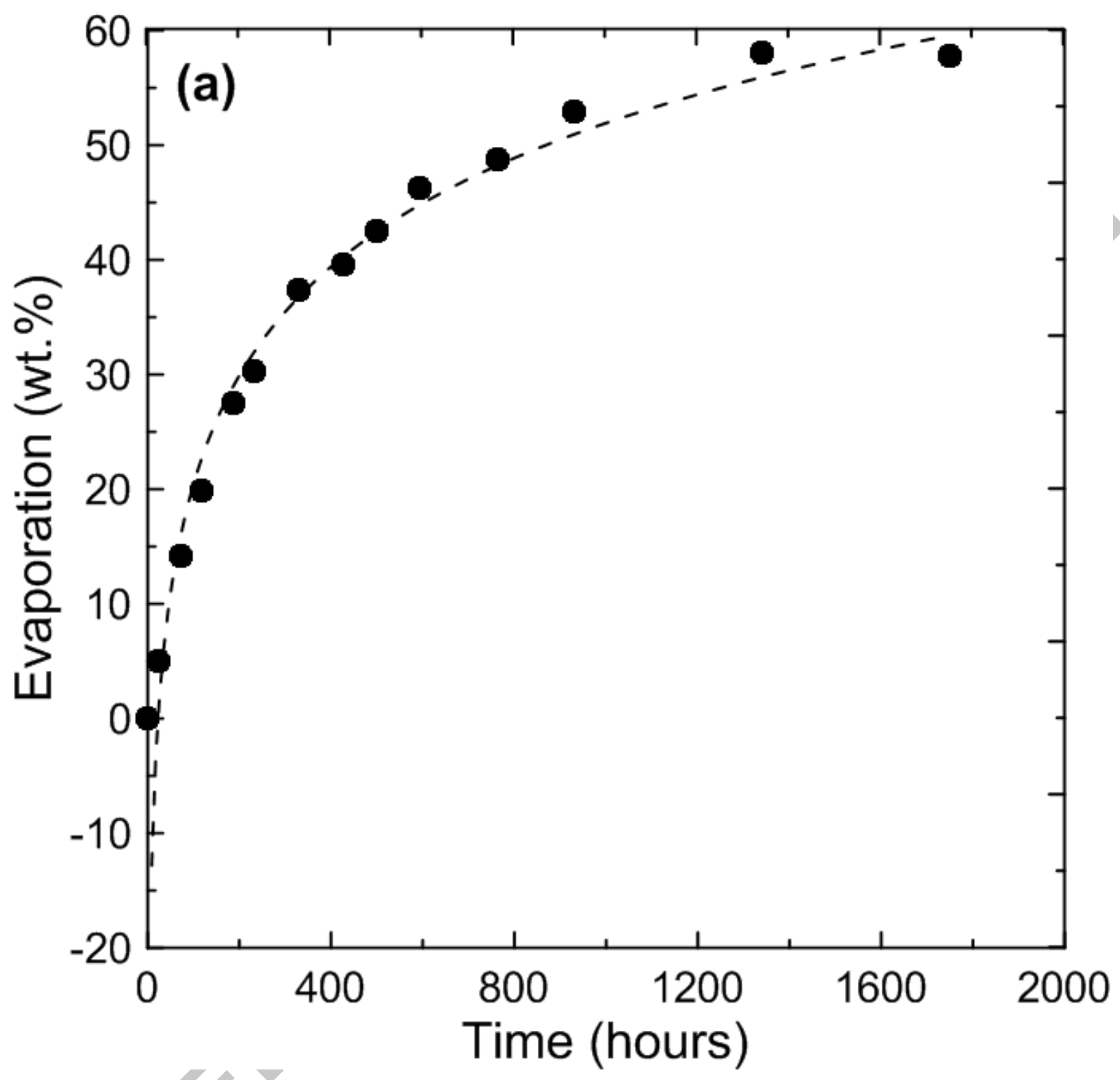




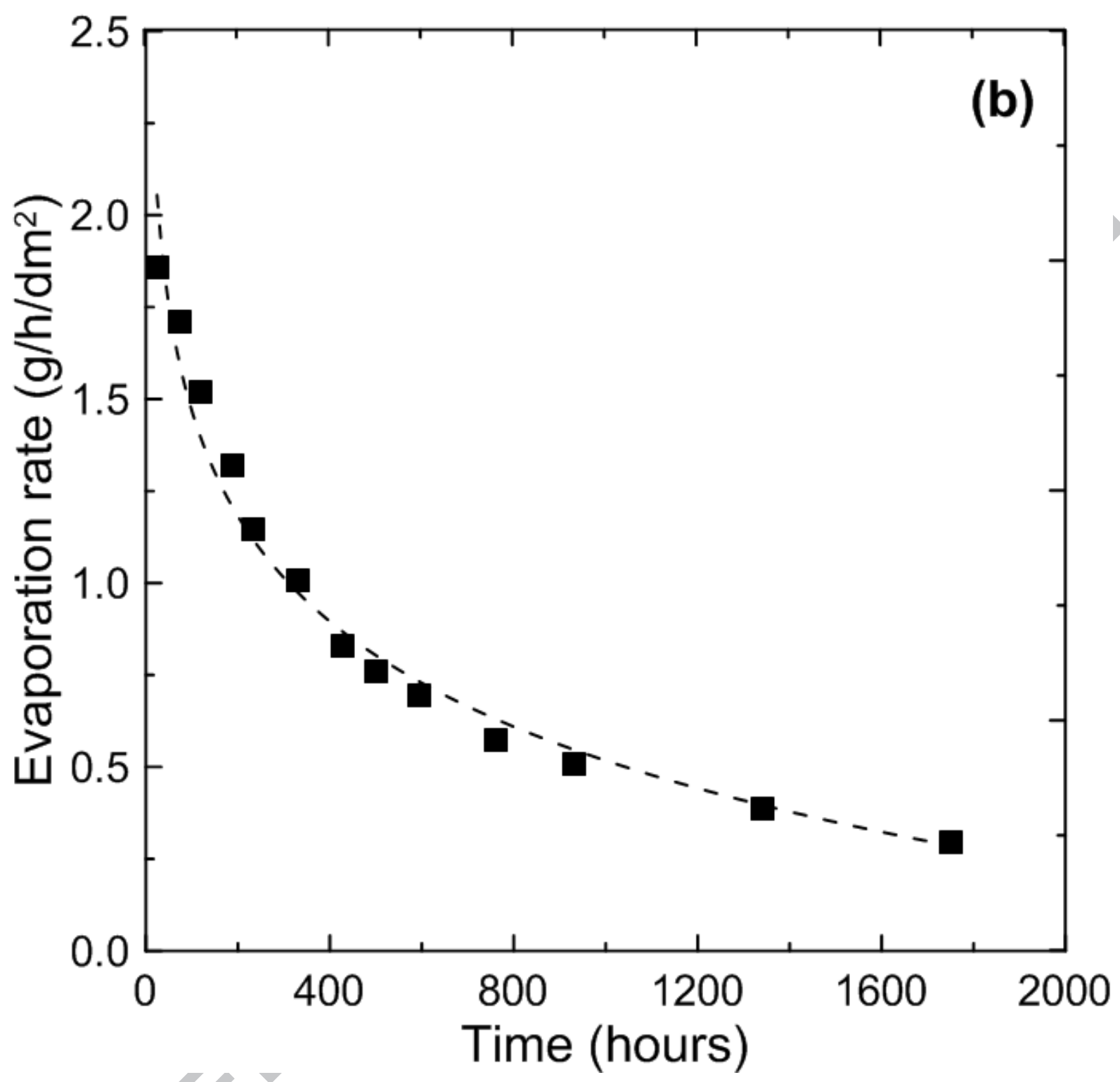




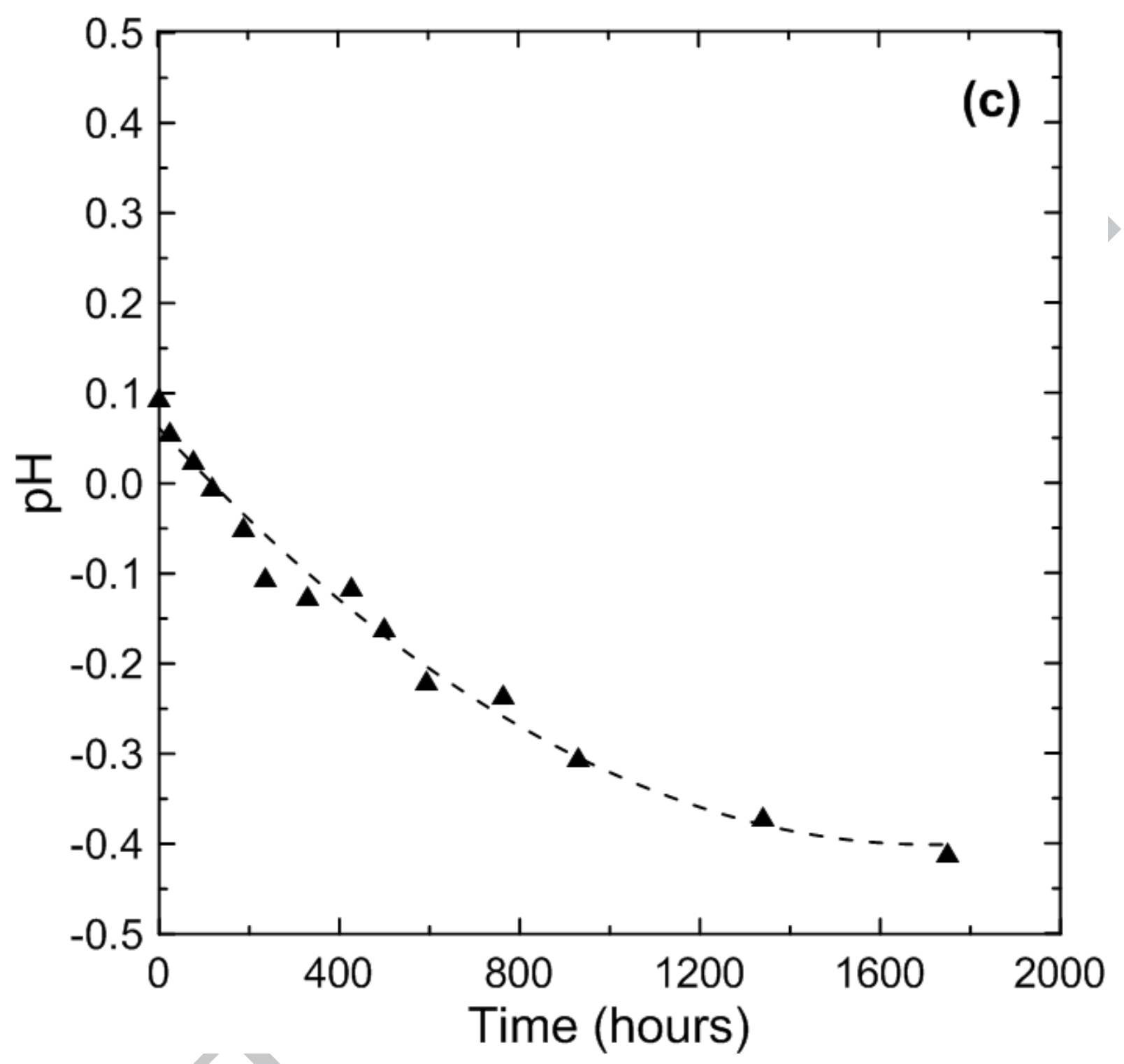




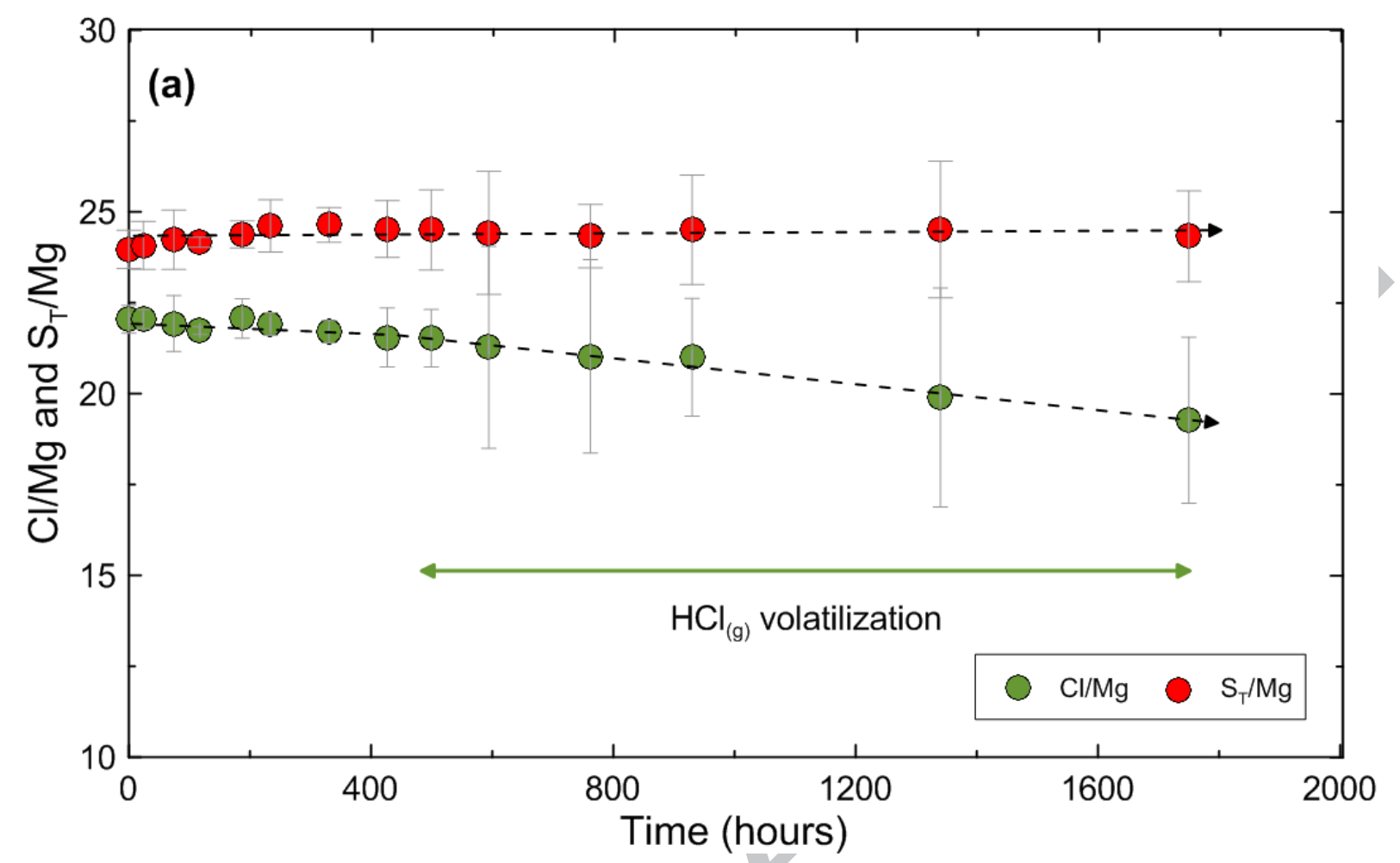




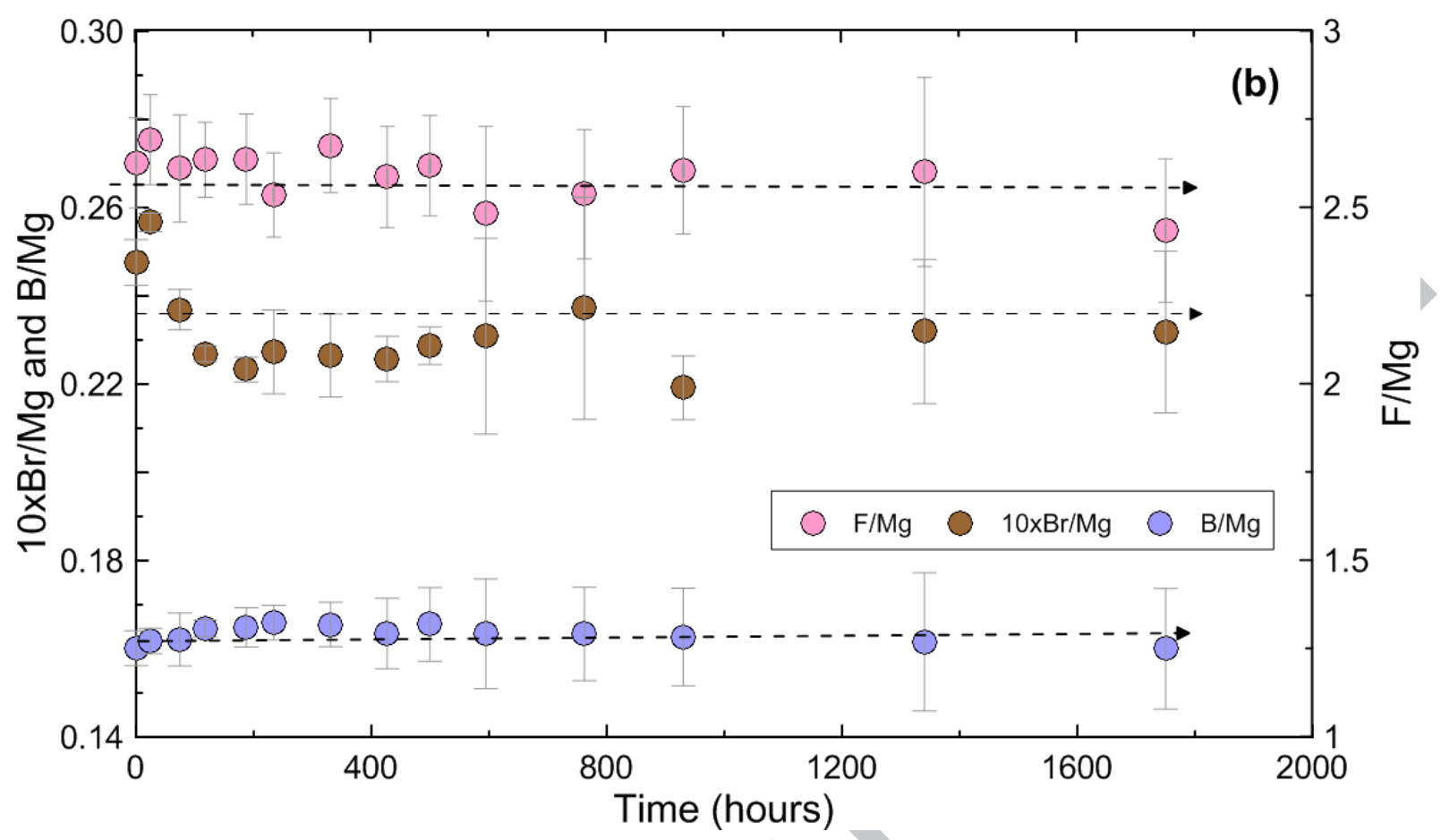




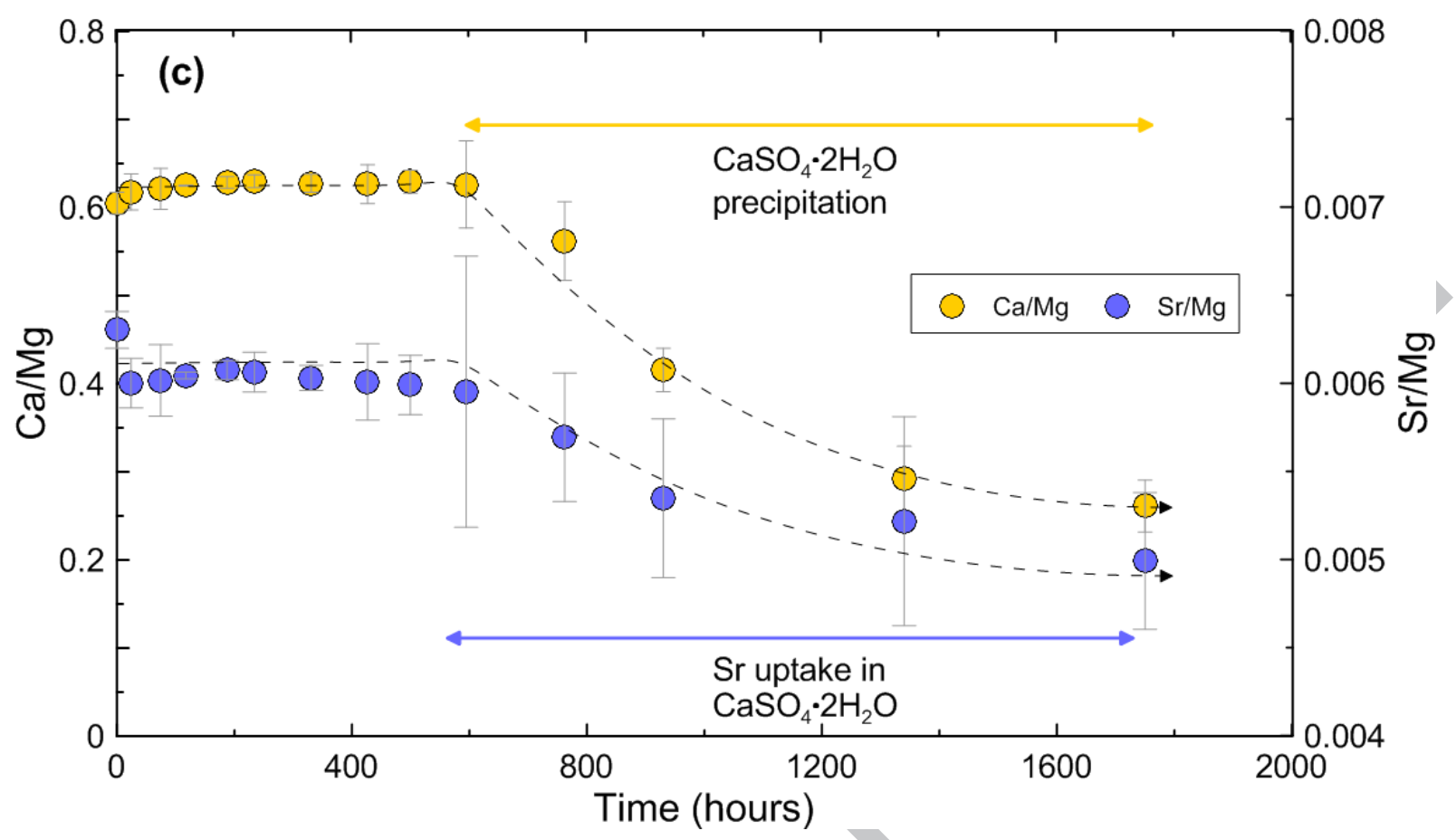




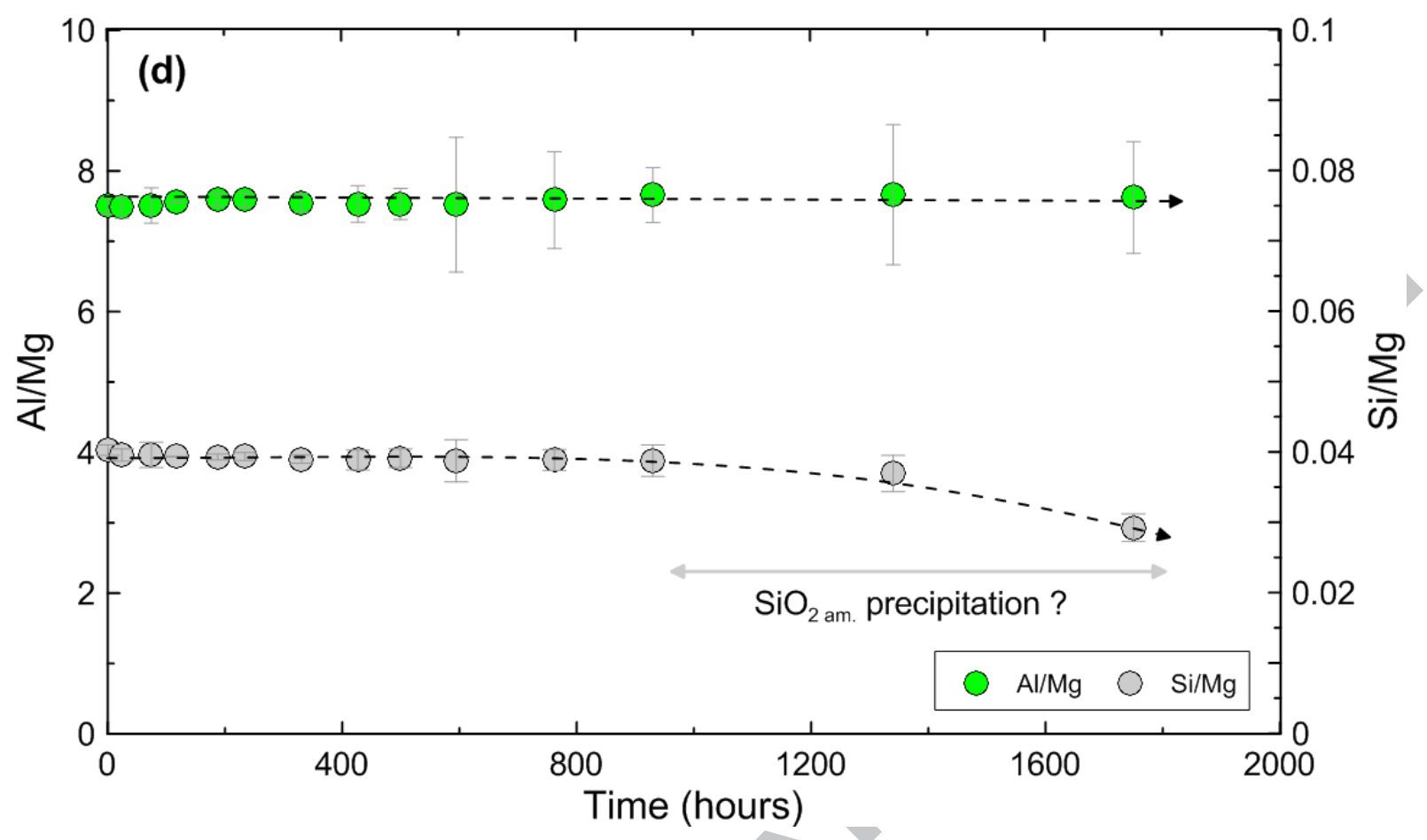




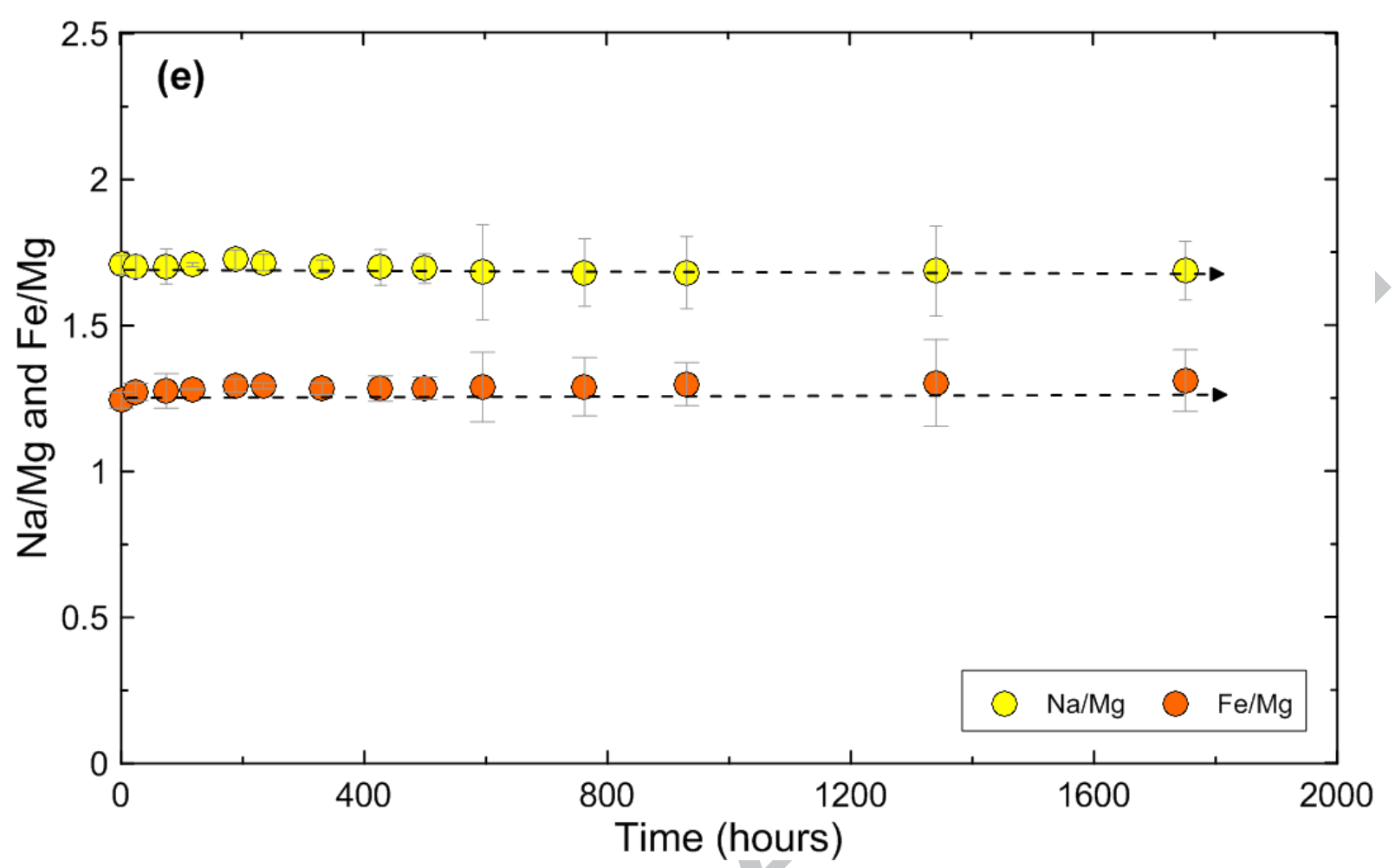




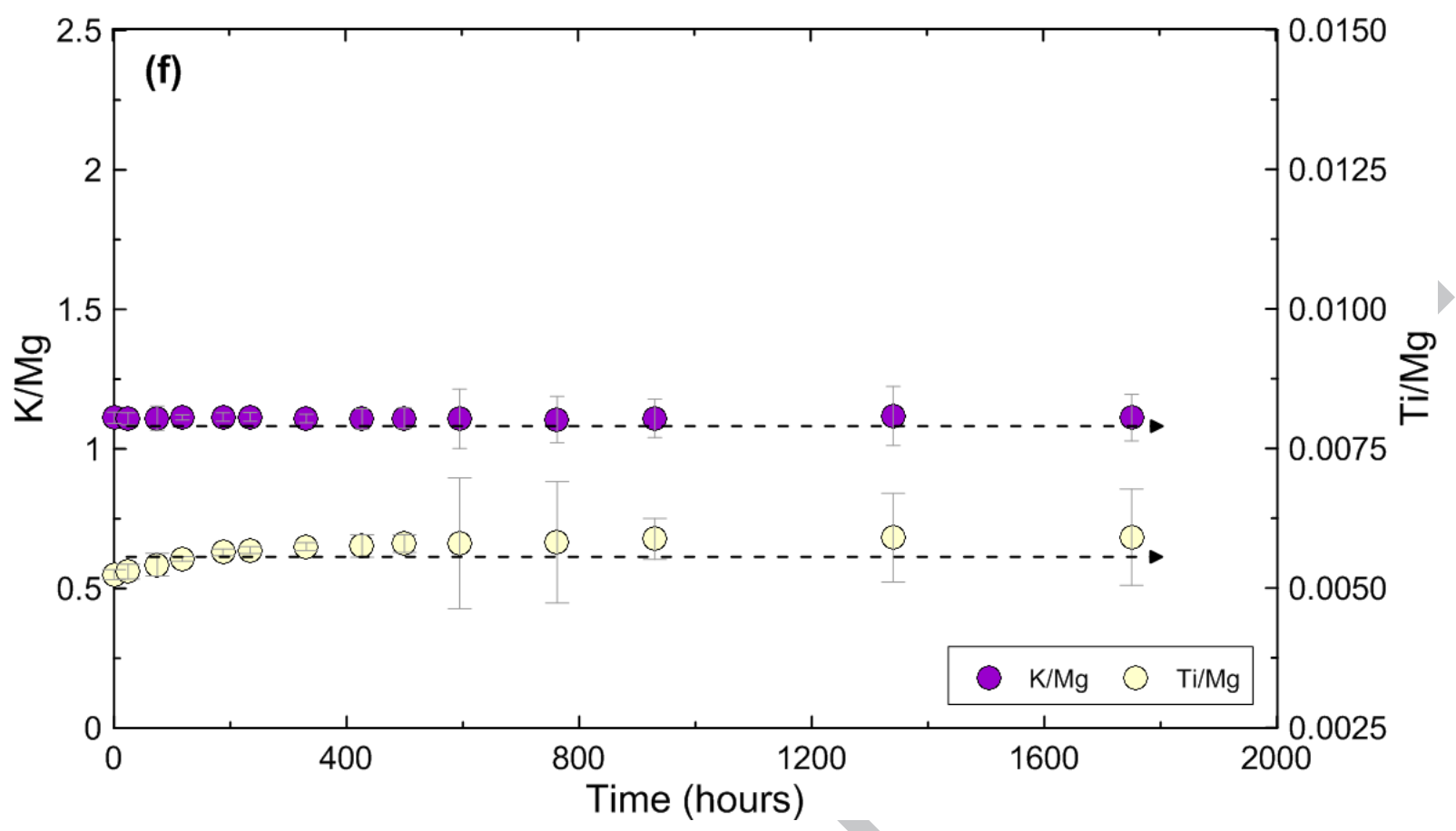




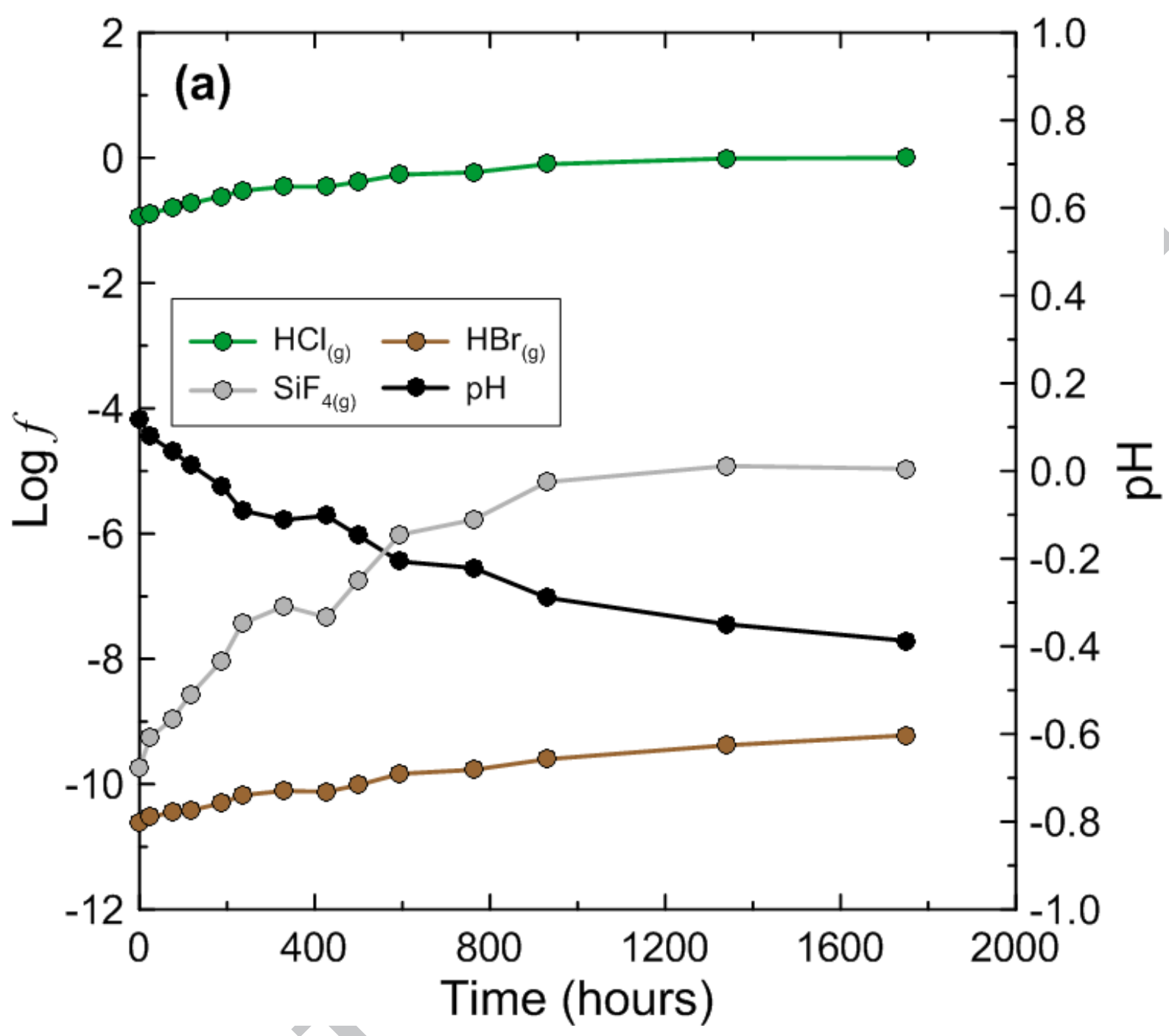




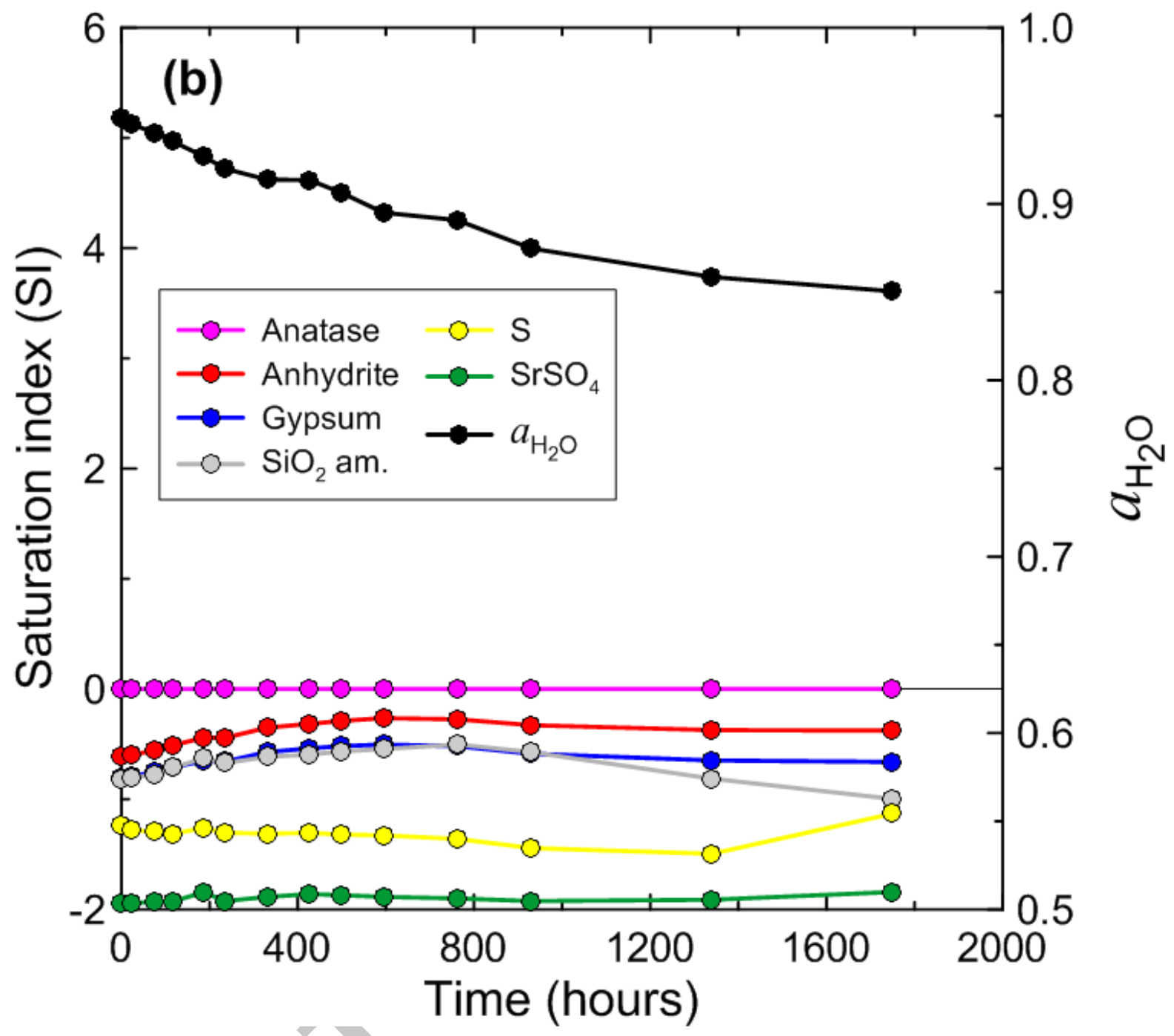



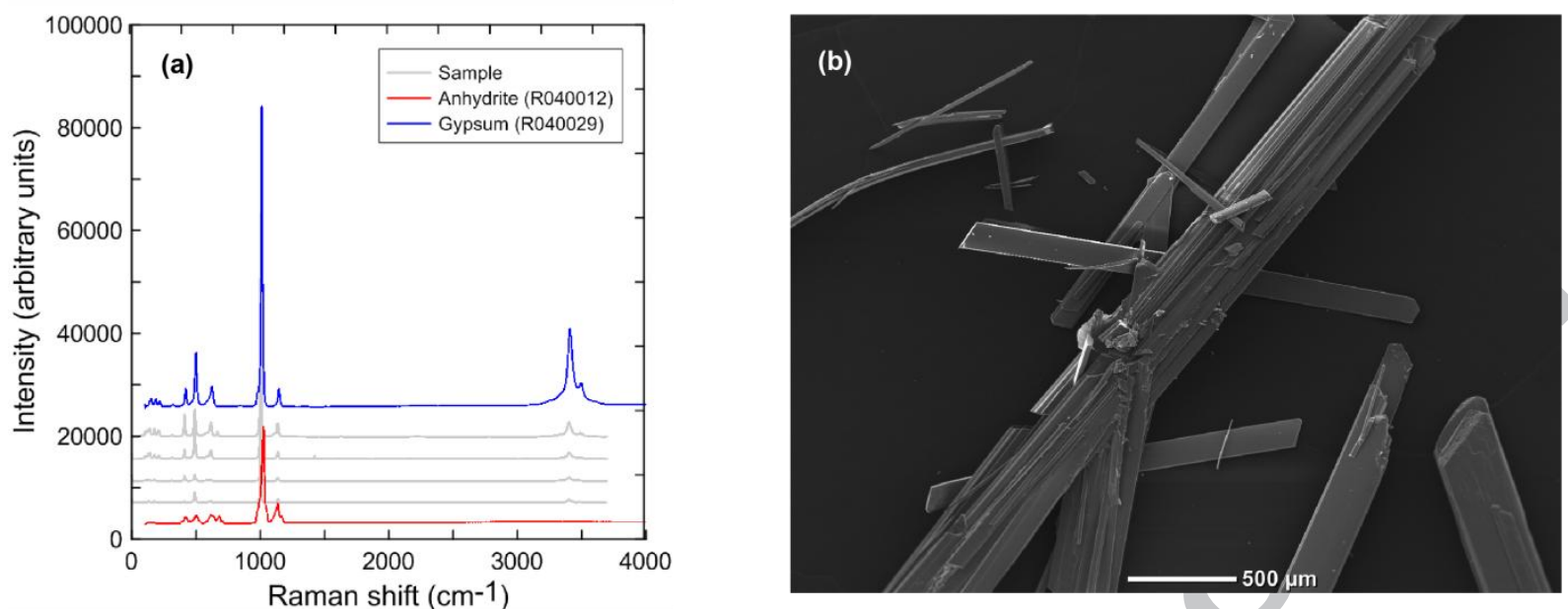


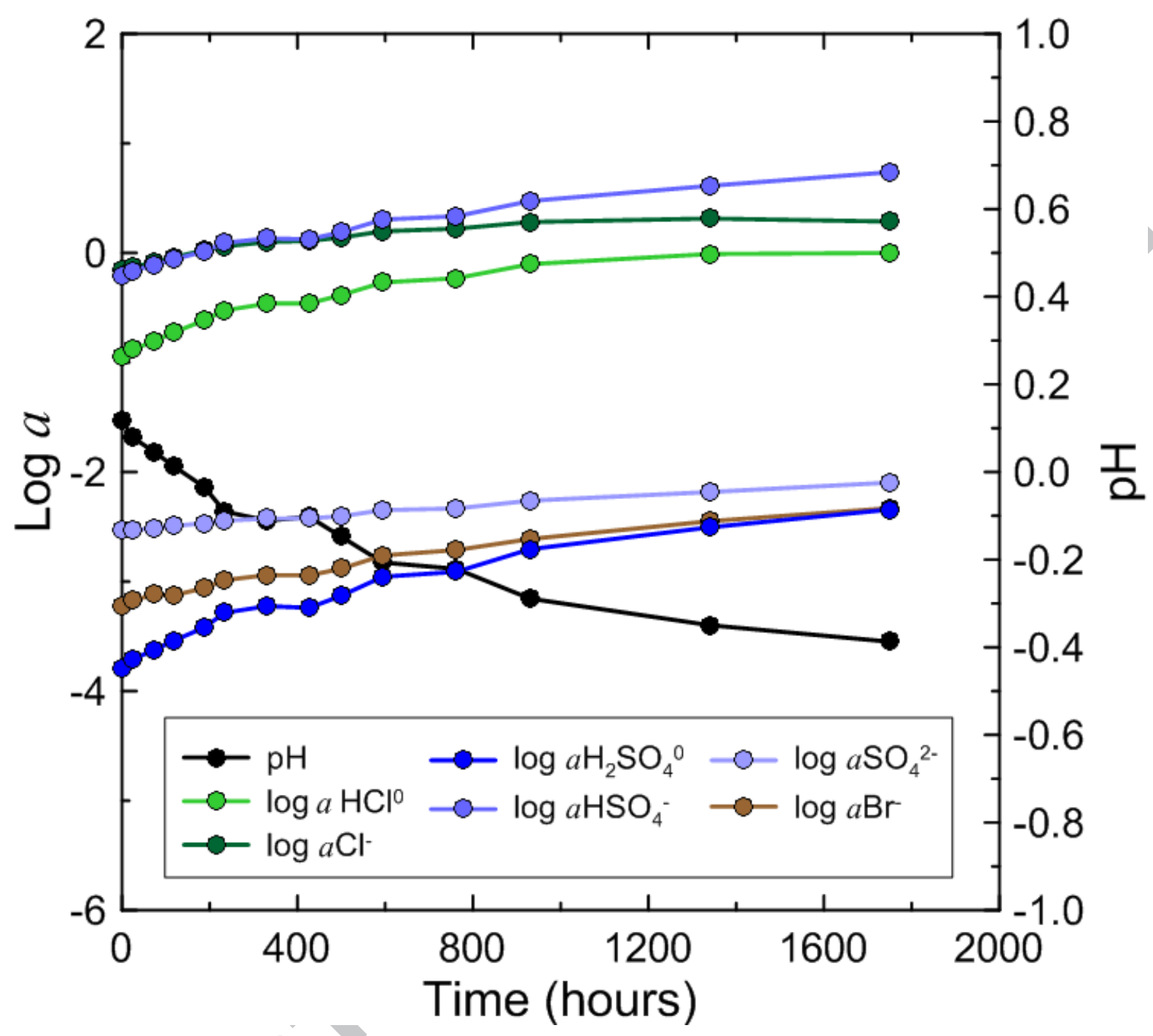




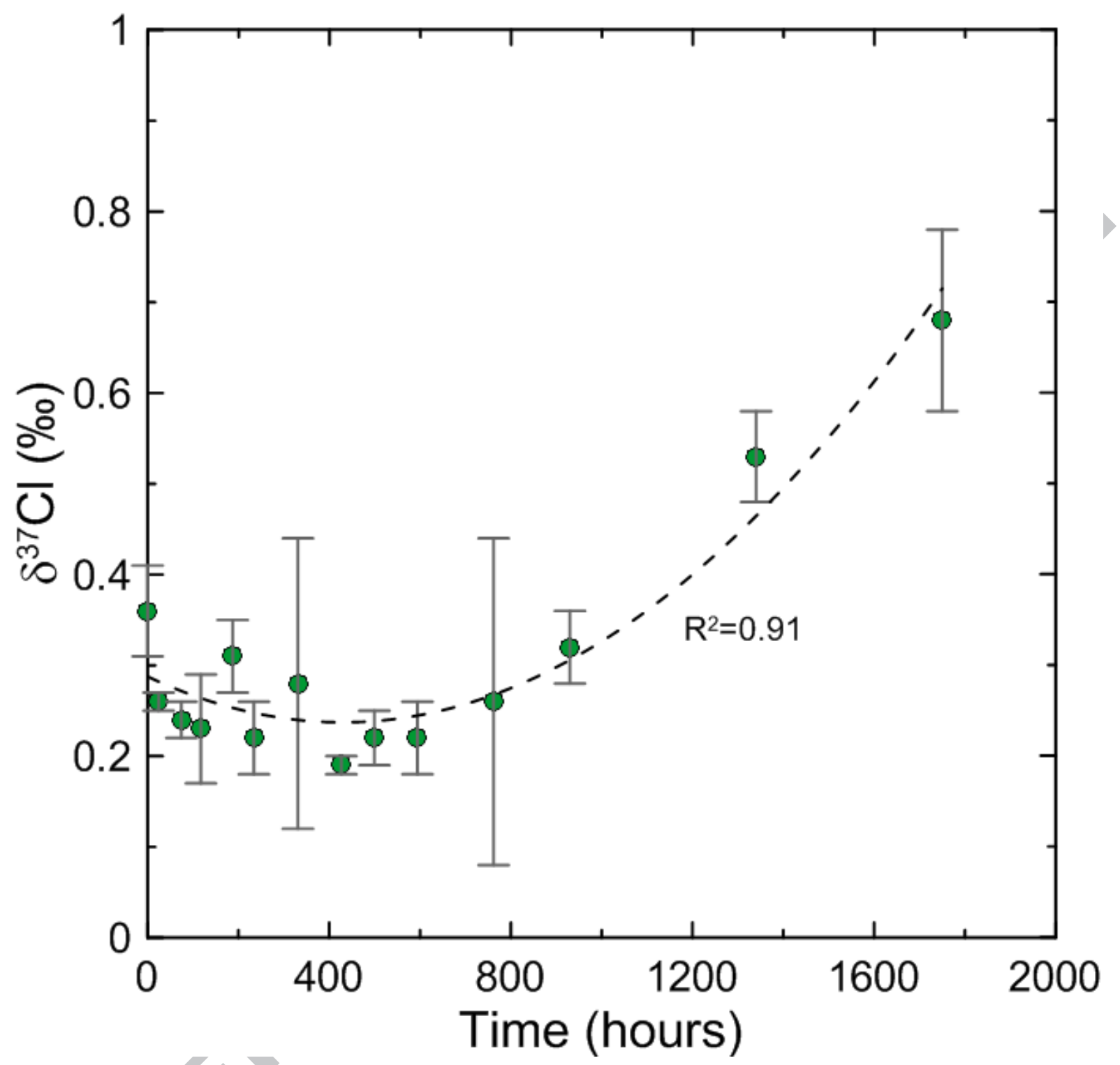




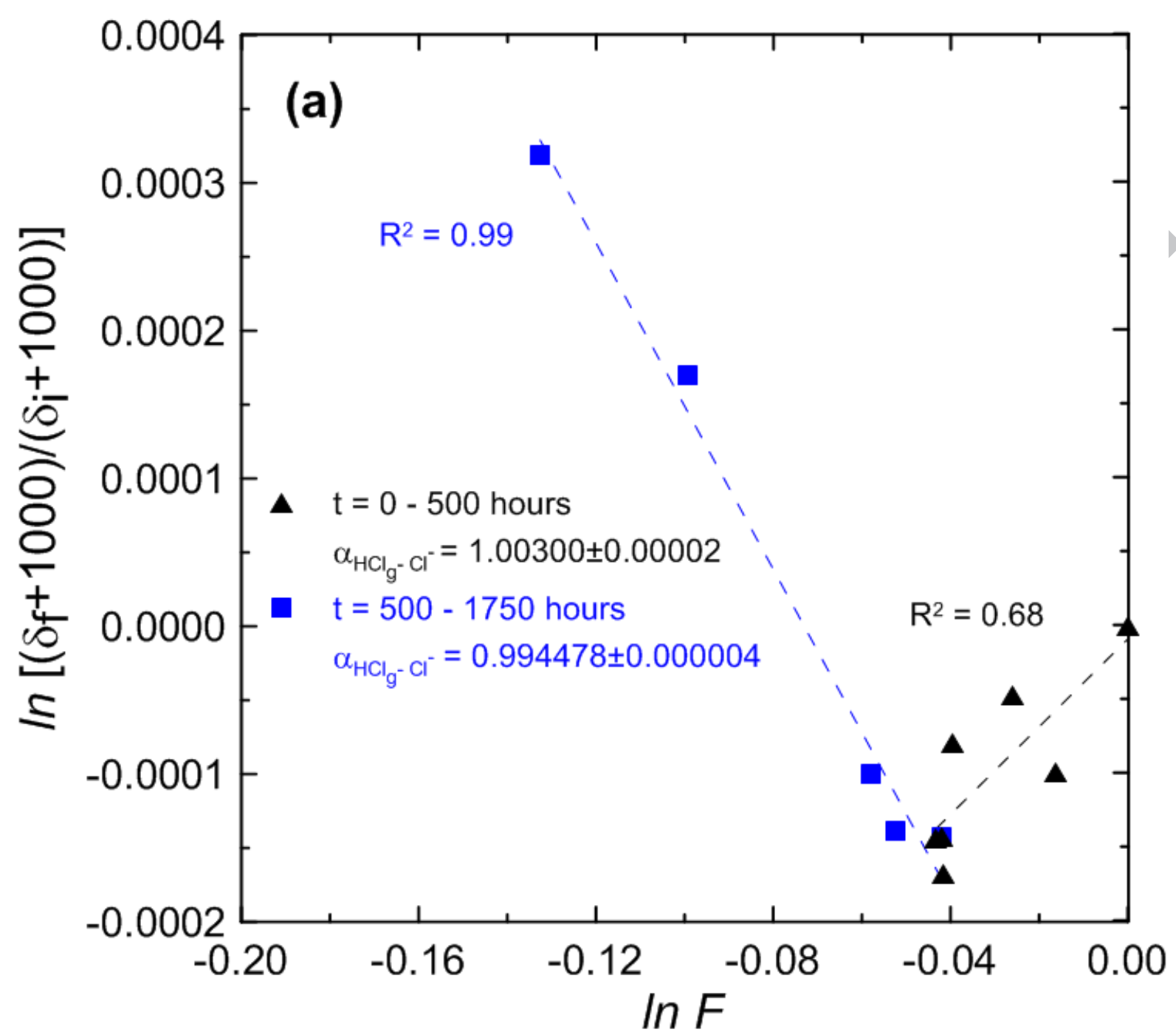




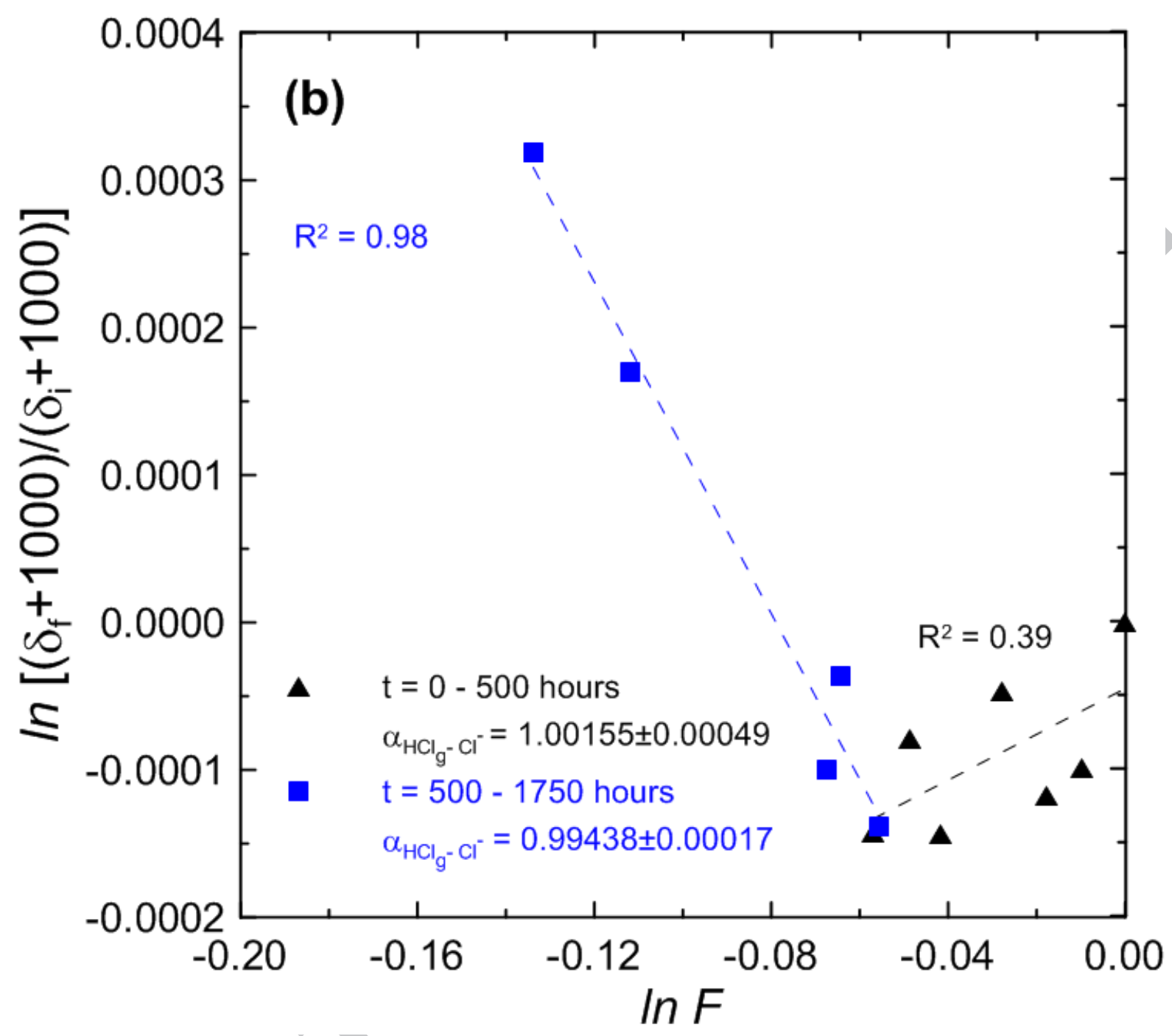




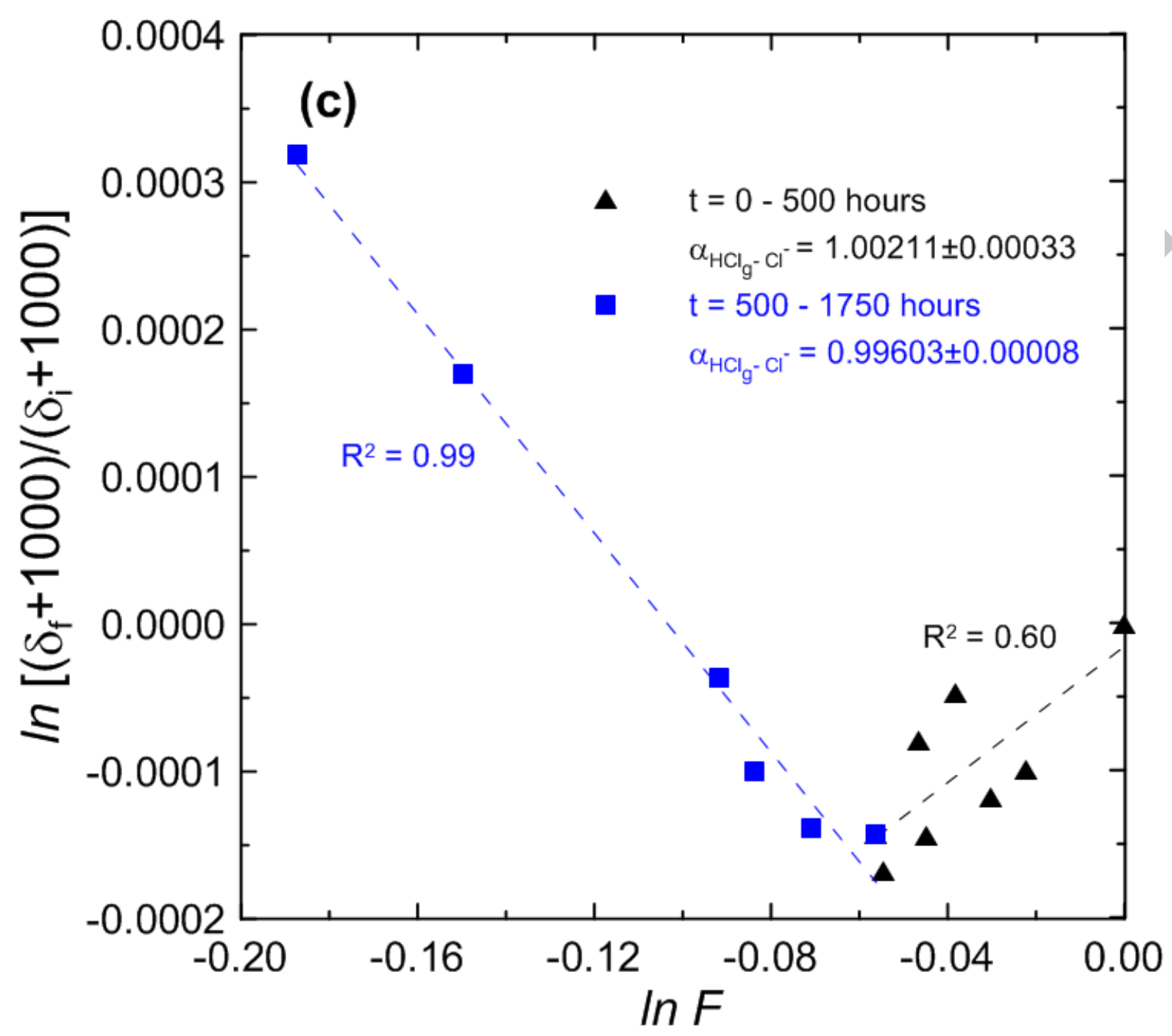




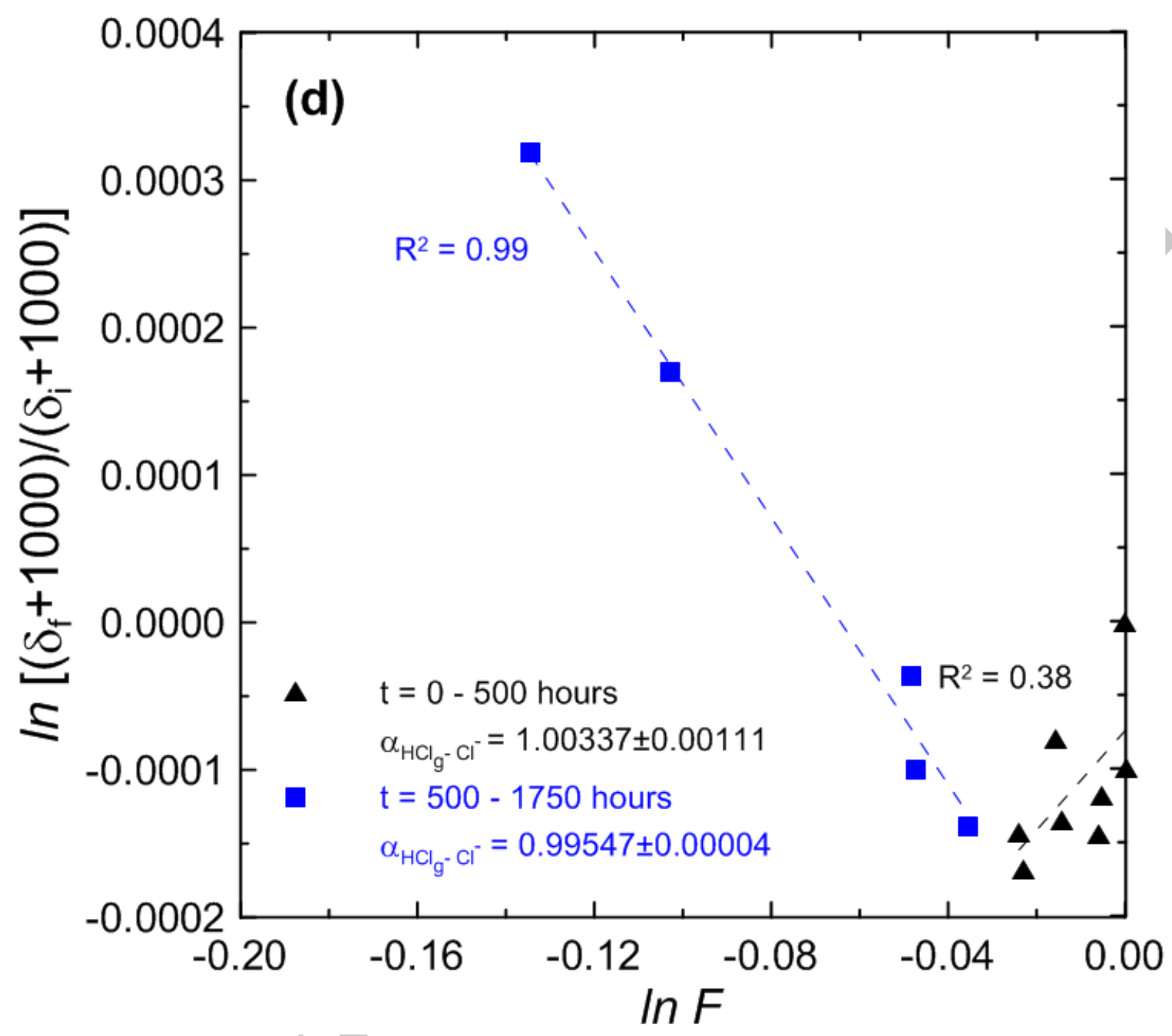




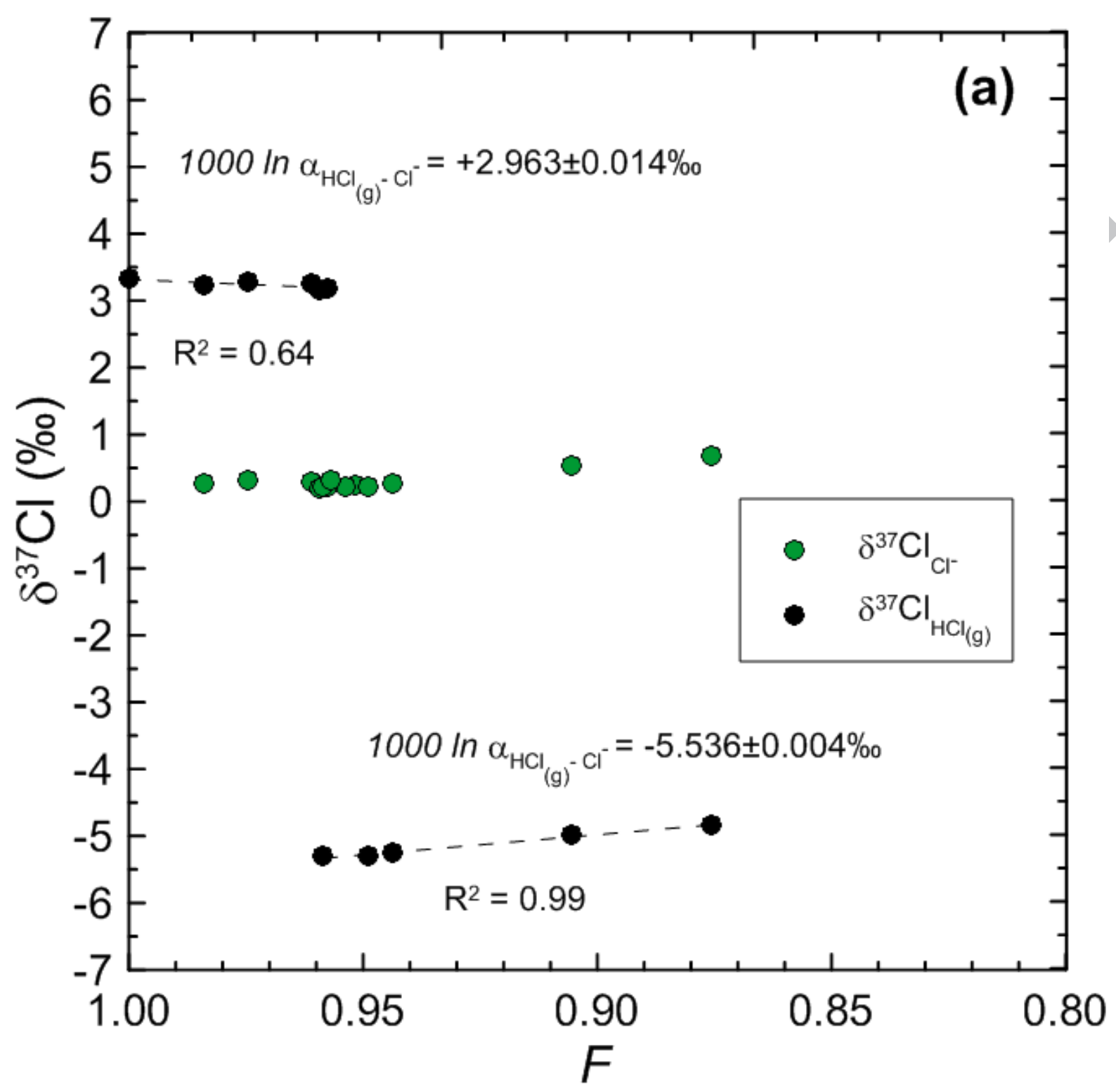




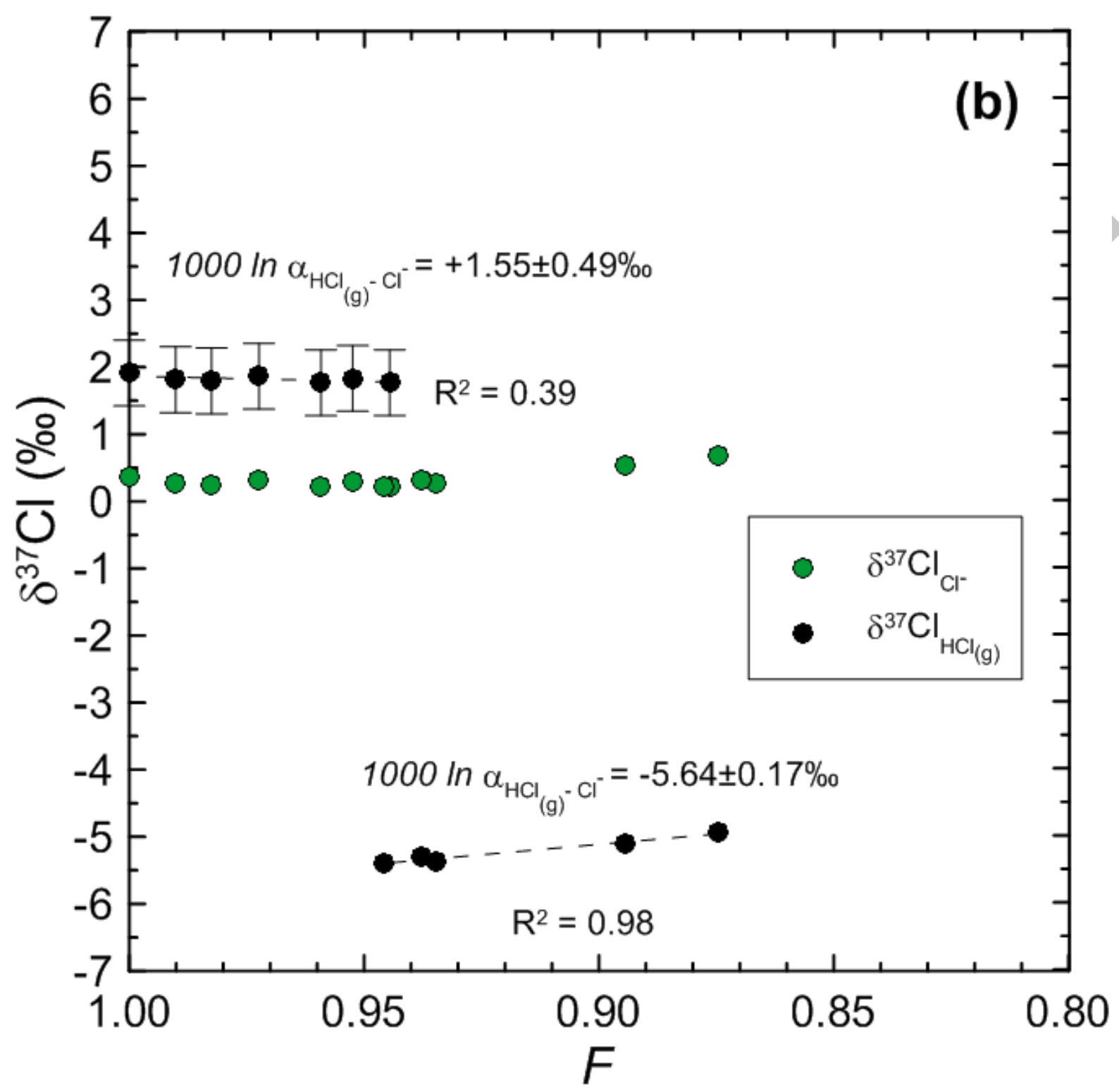




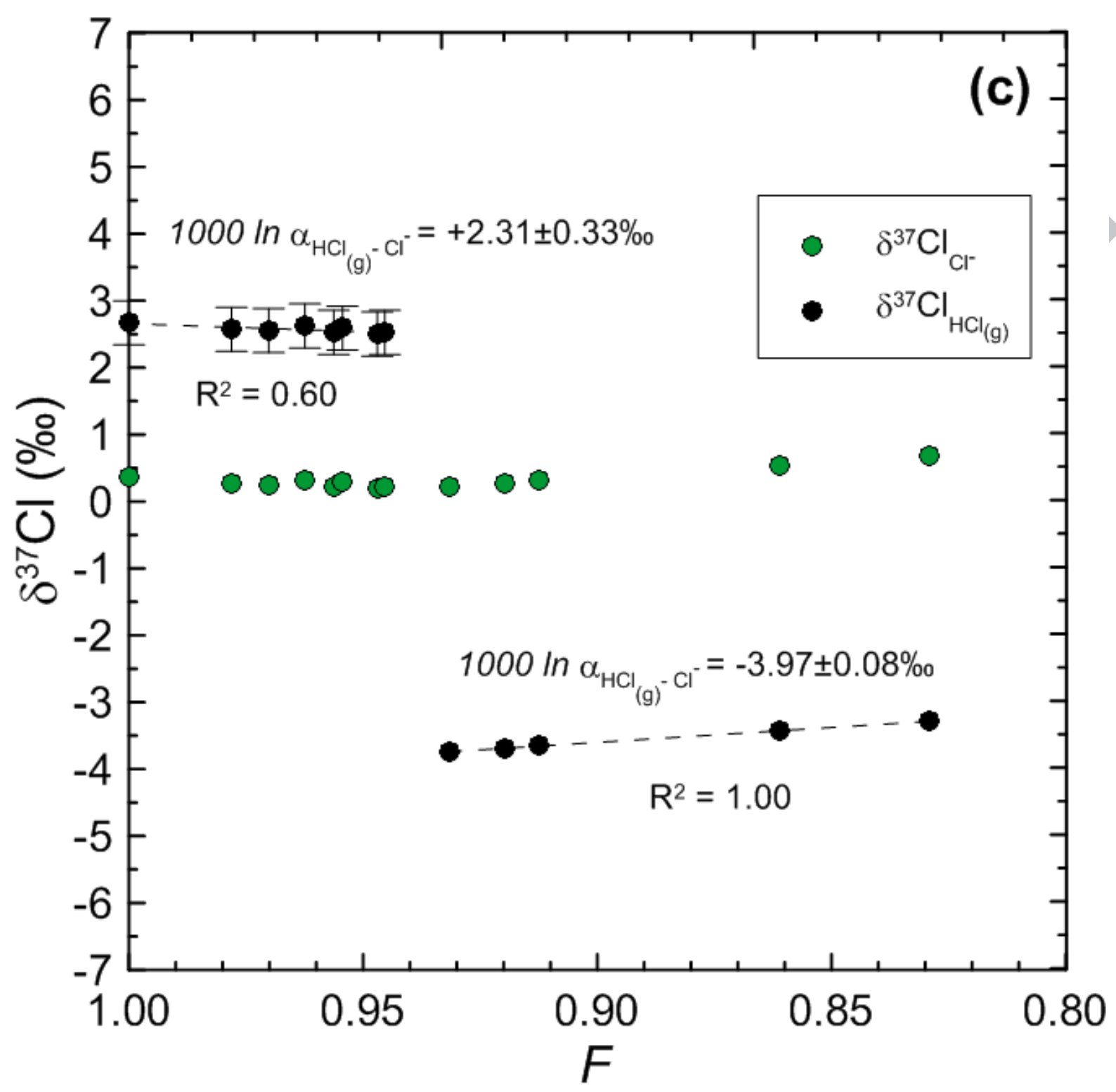




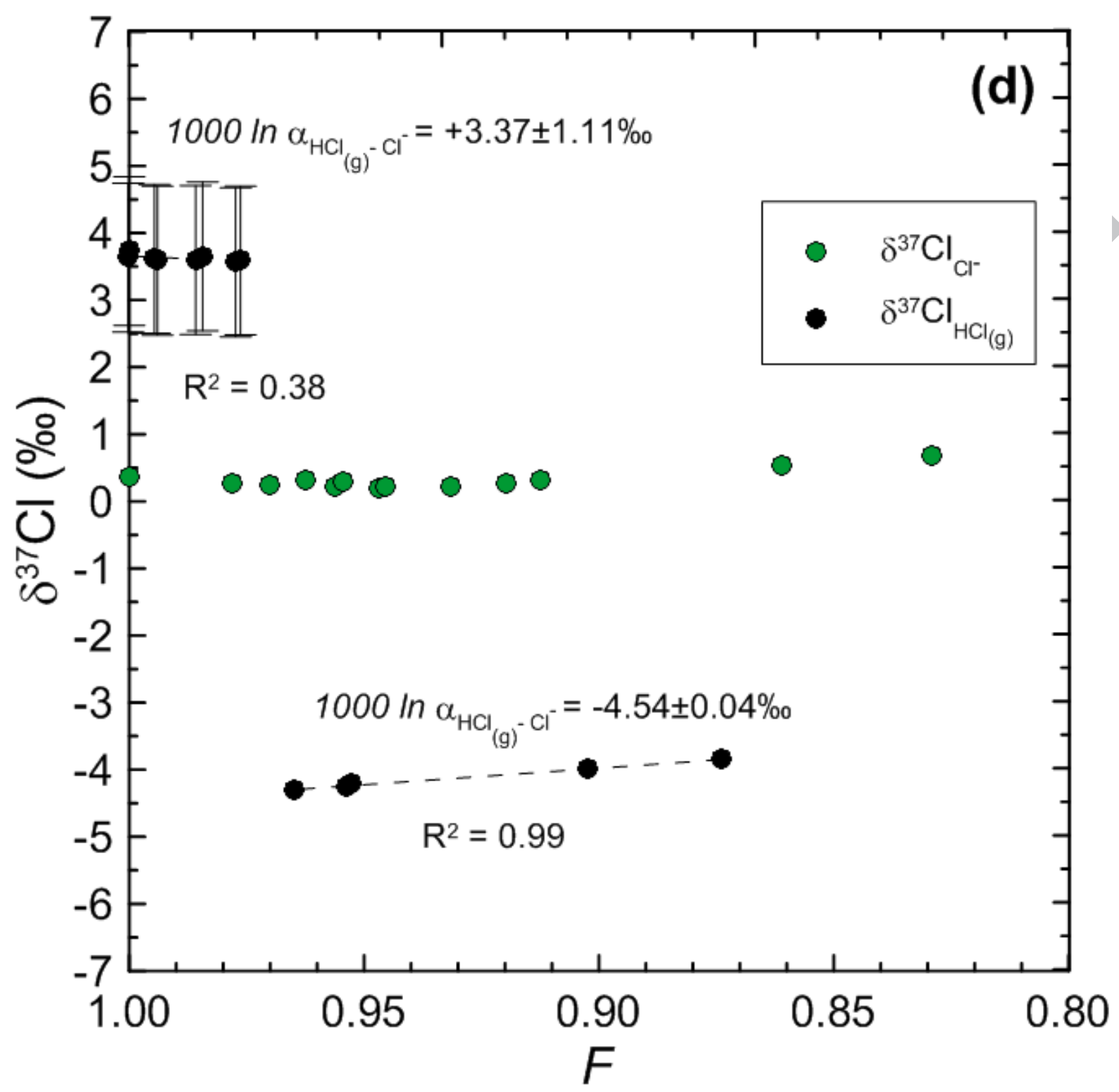




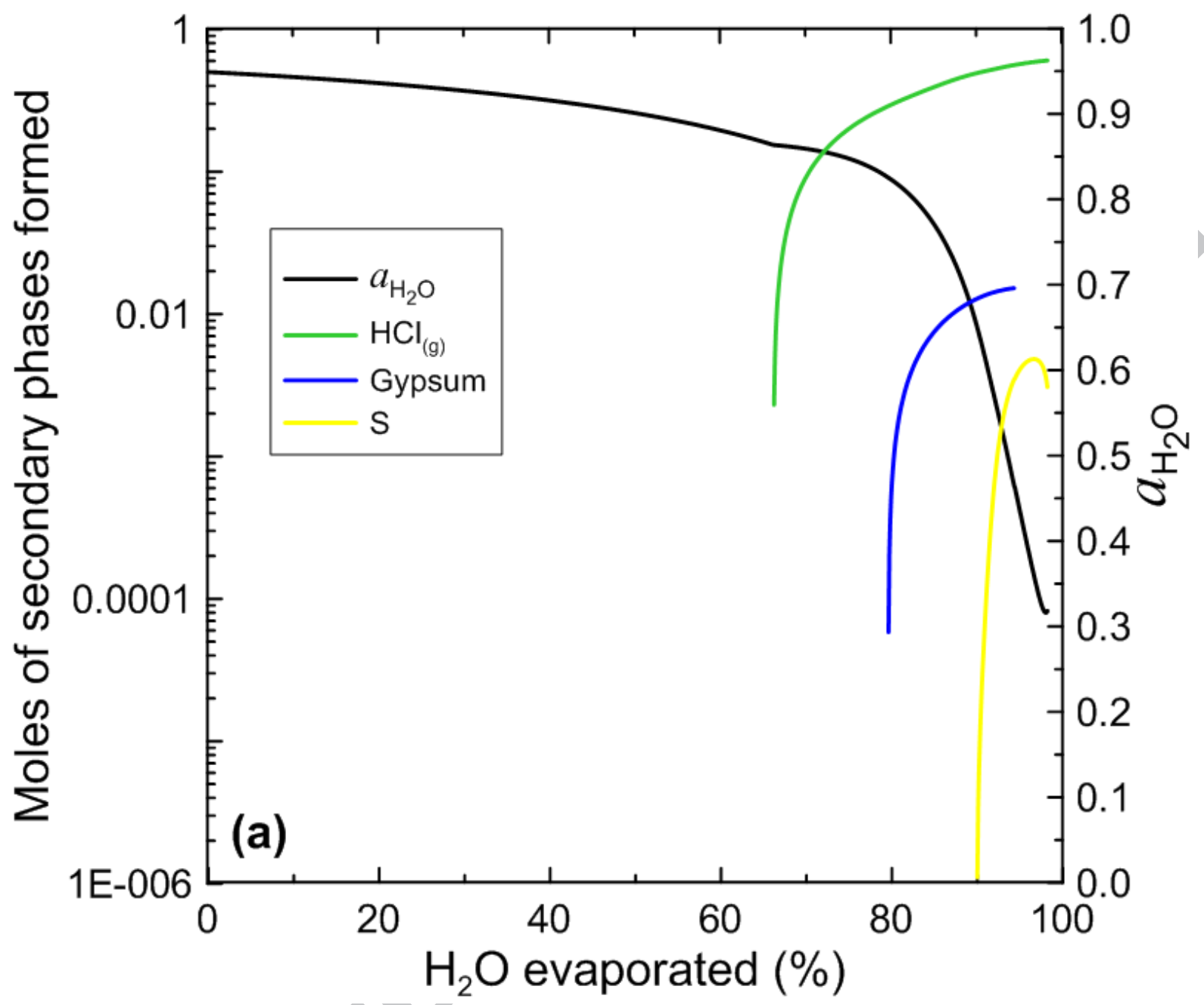




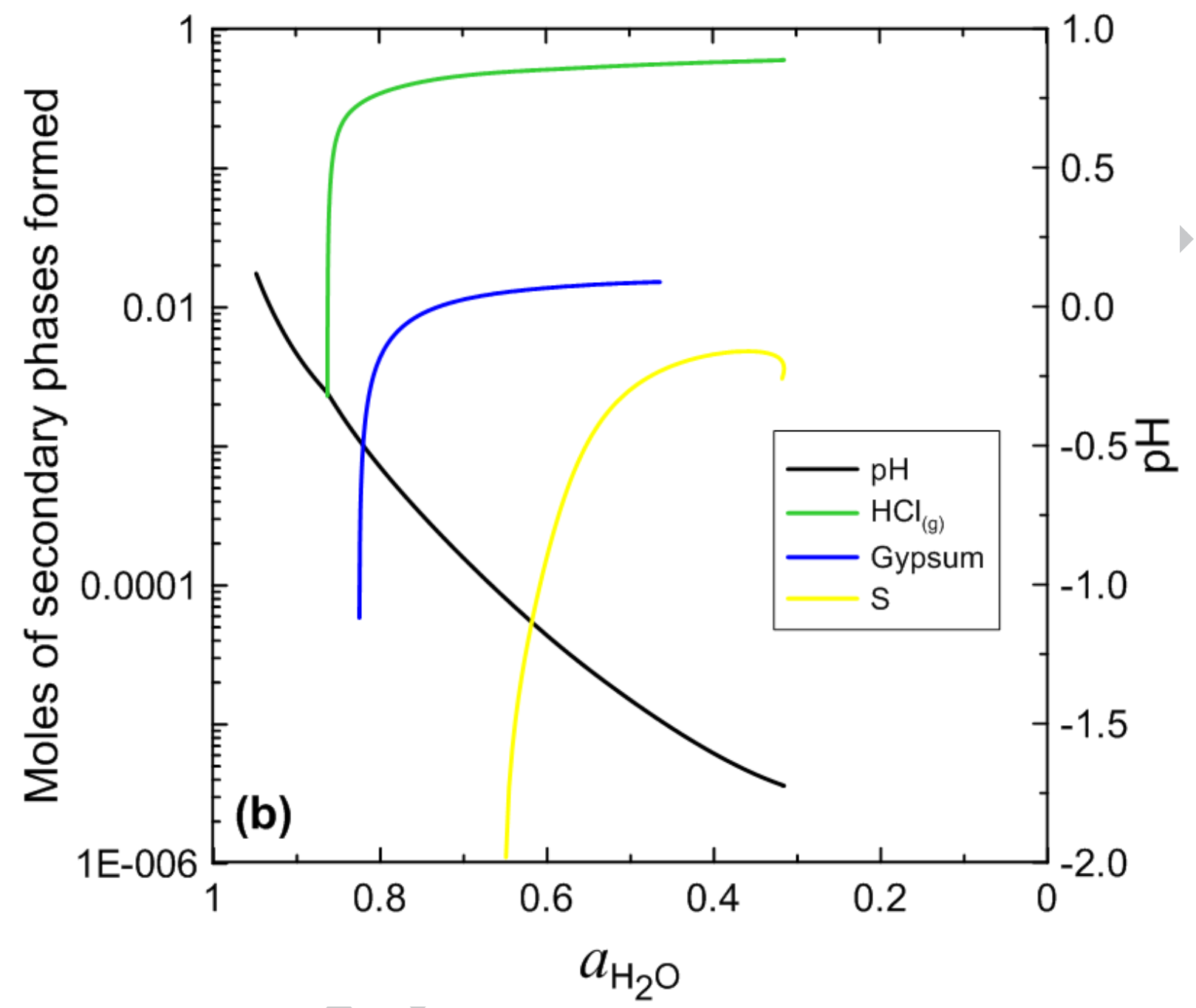




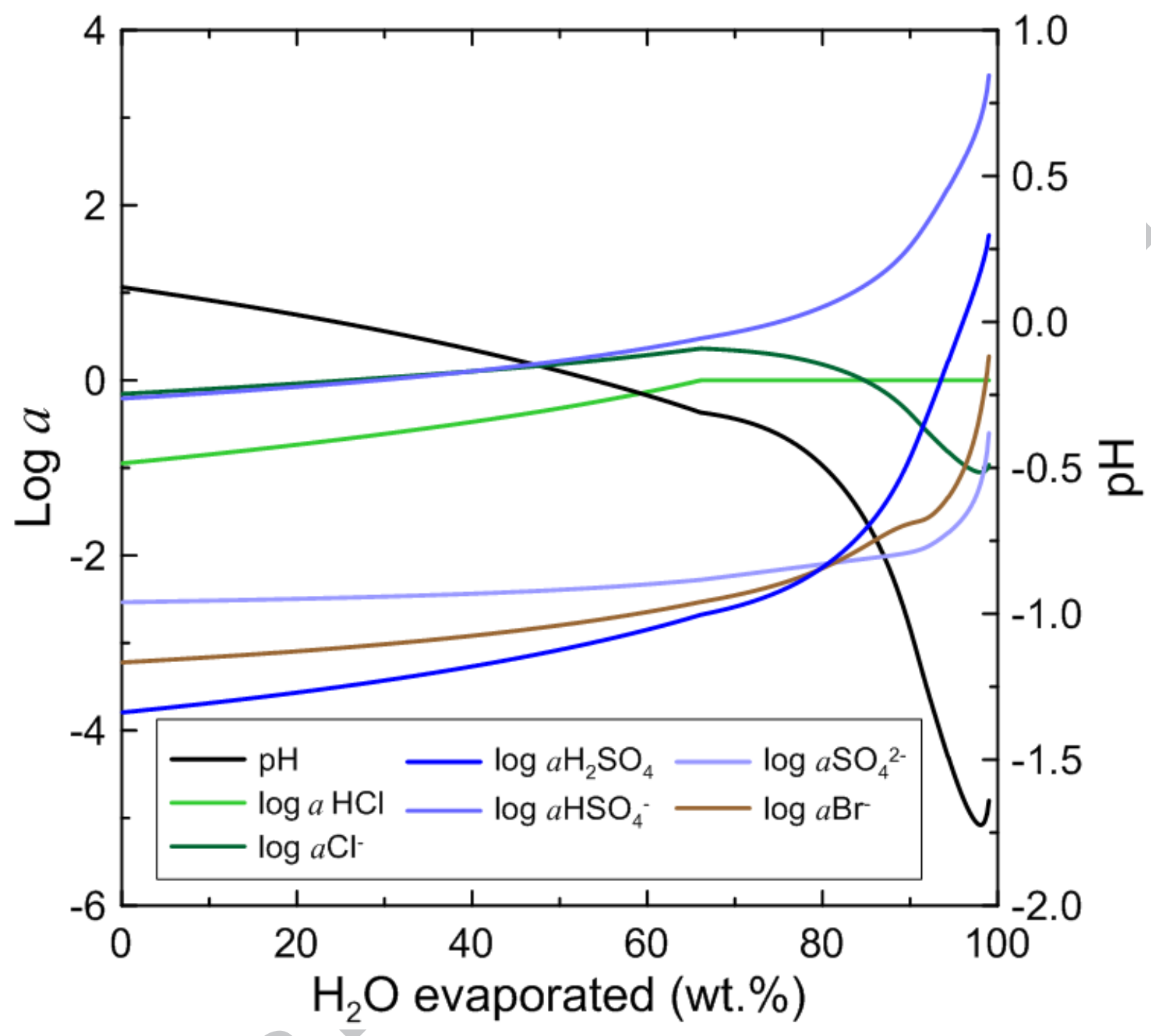




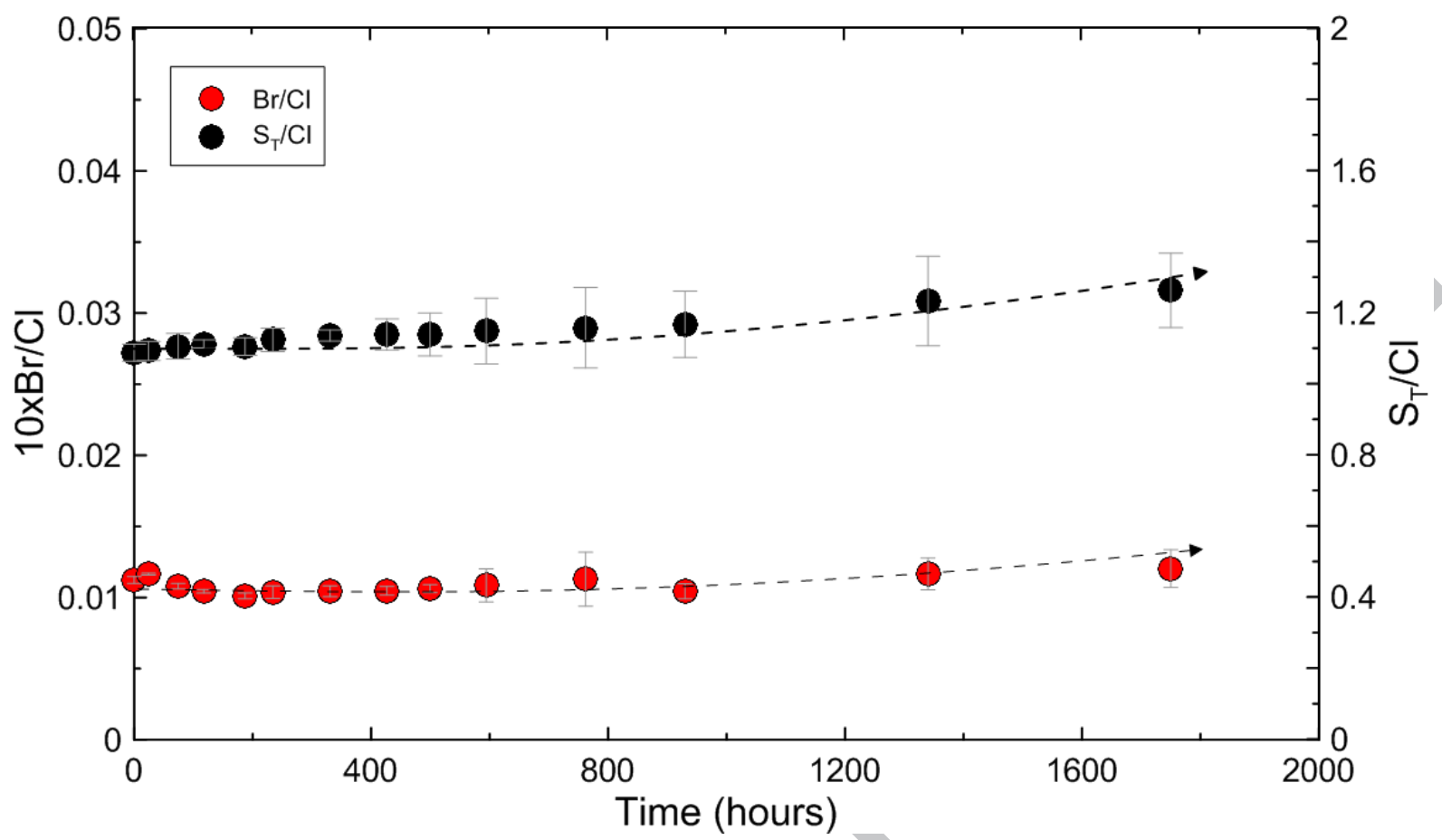




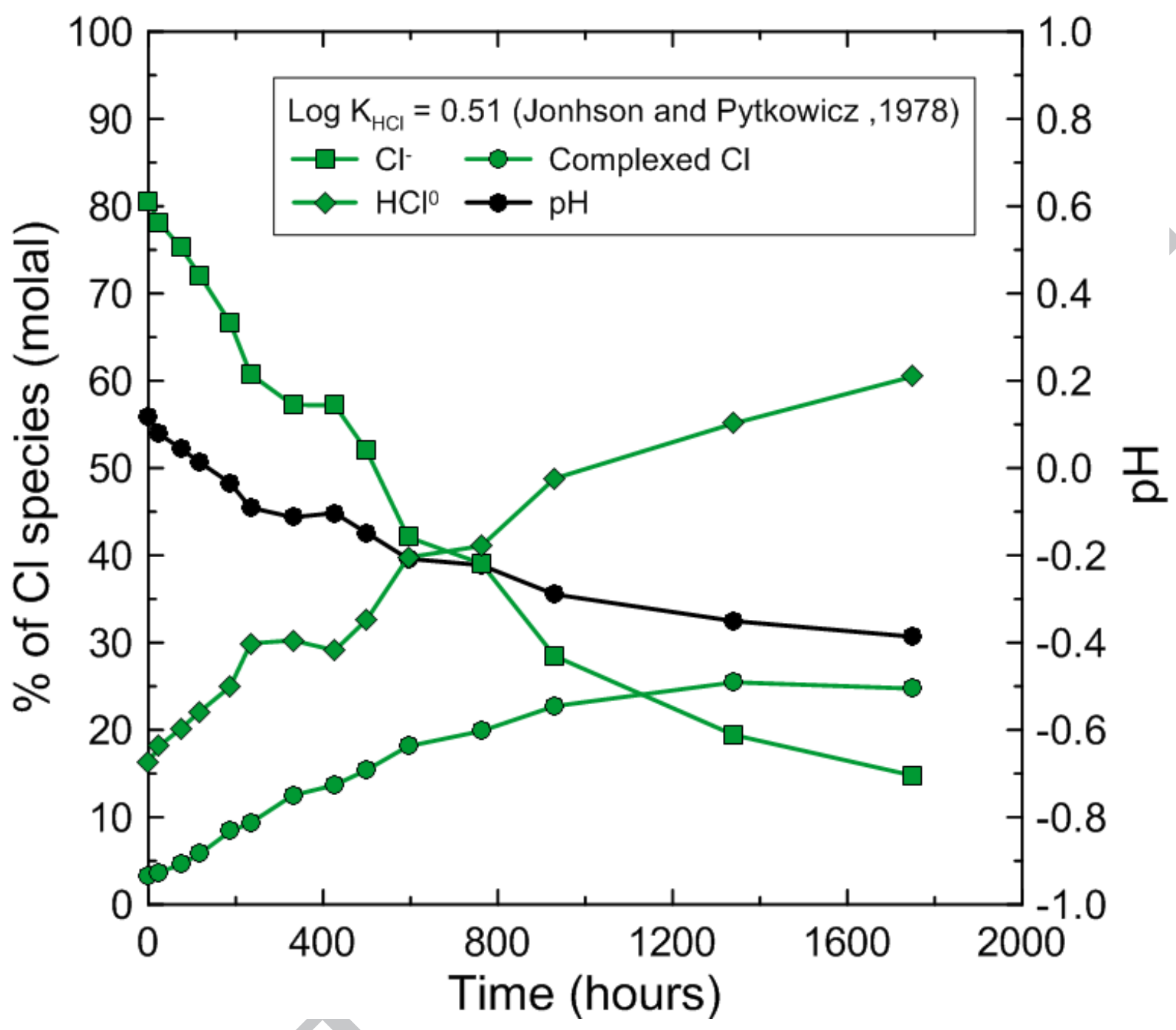




\begin{tabular}{|c|c|c|c|c|c|c|c|c|}
\hline Sample & $\begin{array}{c}\begin{array}{c}\text { Time } \\
\text { (hours) }\end{array} \\
\end{array}$ & $\mathrm{pH}\left(20 \pm 1^{\circ} \mathrm{C}\right)$ & $\mathrm{EC}(\mathrm{ms} / \mathrm{cm})$ & $W_{\text {initial }}(\mathrm{g})$ & $W_{\text {final }}(g)$ & $W_{\text {loss }}(\mathrm{g})$ & $\begin{array}{l}\text { Evaporation (wt. } \\
\%)\end{array}$ & $\begin{array}{c}\text { Evaporation rate } \\
\left(\mathrm{g} / \mathrm{h} / \mathrm{dm}^{2}\right)\end{array}$ \\
\hline 0 & 0 & 0.10 & 283 & n.d. & n.d. & n.d. & n.d. & n.d. \\
\hline 1 & 24 & 0.06 & 288 & 53.7677 & 51.0734 & 2.6944 & 5.01 & 1.86 \\
\hline 2 & 74 & 0.03 & 308 & 53.7424 & 46.1068 & 7.6356 & 14.21 & 1.71 \\
\hline 3 & 117 & -0.01 & 322 & 53.8037 & 43.0863 & 10.7175 & 19.92 & 1.52 \\
\hline 4 & 187 & -0.05 & 342 & 53.7731 & 44.5965 & 9.1765 & 27.52 & 1.32 \\
\hline 5 & 234 & -0.11 & 351 & 53.1711 & 37.0523 & 16.1189 & 30.31 & 1.15 \\
\hline 6 & 331 & -0.13 & 367 & 53.7166 & 33.6840 & 20.0326 & 37.29 & 1.01 \\
\hline 7 & 427 & -0.12 & 376 & 53.6621 & 32.4211 & 21.2410 & 39.58 & 0.83 \\
\hline 8 & 500 & -0.16 & 383 & 53.7552 & 30.9041 & 22.8511 & 42.51 & 0.76 \\
\hline 9 & 594 & -0.22 & 390 & 53.7663 & 28.9339 & 24.8324 & 46.19 & 0.70 \\
\hline 10 & 762 & -0.24 & 395 & 53.7697 & 27.5417 & 26.2281 & 48.78 & 0.57 \\
\hline 11 & 930 & -0.31 & 401 & 53.7009 & 25.3190 & 28.3819 & 52.85 & 0.51 \\
\hline 12 & 1340 & -0.37 & 397 & 53.7580 & 22.5509 & 31.2071 & 58.05 & 0.39 \\
\hline 13 & 1750 & -0.41 & 392 & 53.6935 & 22.6709 & 31.0226 & 57.78 & 0.29 \\
\hline
\end{tabular}




\begin{tabular}{|c|c|c|c|c|c|c|c|c|c|c|c|c|c|c|c|c|c|}
\hline Sample & $\begin{array}{l}\text { Time } \\
\text { (hours) }\end{array}$ & $\begin{array}{c}\mathrm{pH} \\
\left(20 \pm 1^{\circ} \mathrm{C}\right)\end{array}$ & $\begin{array}{c}S_{T}{ }^{a} \\
(\mathrm{mg} / \mathrm{kg})\end{array}$ & $\begin{array}{c}\mathrm{Cl} \\
(\mathrm{mg} / \mathrm{kg})\end{array}$ & $\begin{array}{c}\mathrm{F} \\
(\mathrm{mg} / \mathrm{kg})\end{array}$ & $\begin{array}{c}\text { Al } \\
(\mathrm{mg} / \mathrm{kg})\end{array}$ & $\begin{array}{c}\text { B } \\
(\mathrm{mg} / \mathrm{kg})\end{array}$ & $\begin{array}{c}\mathrm{Br} \\
(\mathrm{mg} / \mathrm{kg})\end{array}$ & $\begin{array}{c}\mathrm{Ca} \\
(\mathrm{mg} / \mathrm{kg})\end{array}$ & $\begin{array}{c}\mathrm{Fe} \\
(\mathrm{mg} / \mathrm{kg})\end{array}$ & $\begin{array}{c}\mathrm{K} \\
(\mathrm{mg} / \mathrm{kg})\end{array}$ & $\begin{array}{c}\mathrm{Mg} \\
(\mathrm{mg} / \mathrm{kg})\end{array}$ & $\begin{array}{c}\mathrm{Na} \\
(\mathrm{mg} / \mathrm{kg})\end{array}$ & $\begin{array}{c}\mathrm{Si} \\
(\mathrm{mg} / \mathrm{kg})\end{array}$ & $\begin{array}{c}\mathrm{Sr} \\
(\mathrm{mg} / \mathrm{kg})\end{array}$ & $\begin{array}{c}\mathrm{Ti} \\
(\mathrm{mg} / \mathrm{kg})\end{array}$ & $\begin{array}{l}\mathrm{TDS}^{\mathrm{b}} \\
(\mathrm{g} / \mathrm{kg})\end{array}$ \\
\hline $0^{c}$ & 0 & 0.10 & 21800 & 22100 & 1410 & 5730 & 49 & 56 & 690 & 1970 & 1230 & 690 & 1110 & 32 & 15 & 7.1 & 96 \\
\hline 1 & 24 & 0.06 & 22600 & 22900 & 1500 & 5920 & 51 & 60 & 730 & 2080 & 1270 & 710 & 1150 & 33 & 15 & 7.4 & 100 \\
\hline 2 & 74 & 0.03 & 24500 & 24500 & 1570 & 6400 & 55 & 60 & 790 & 2250 & 1370 & 770 & 1240 & 35 & 17 & 8.2 & 111 \\
\hline 3 & 117 & -0.01 & 26500 & 26300 & 1710 & 6970 & 61 & 62 & 860 & 2450 & 1490 & 830 & 1340 & 38 & 18 & 9.0 & 119 \\
\hline 4 & 187 & -0.05 & 29700 & 29700 & 1900 & 7790 & 68 & 68 & 960 & 2750 & 1660 & 920 & 1510 & 42 & 20 & 10.3 & 137 \\
\hline 5 & 234 & -0.11 & 30900 & 30400 & 1880 & 8010 & 70 & 71 & 990 & 2830 & 1710 & 950 & 1540 & 43 & 21 & 10.6 & 142 \\
\hline 6 & 331 & -0.13 & 34800 & 33900 & 2240 & 8970 & 79 & 80 & 1110 & 3160 & 1910 & 1070 & 1730 & 48 & 23 & 12.1 & 160 \\
\hline 7 & 427 & -0.12 & 36200 & 35100 & 2260 & 9340 & 81 & 83 & 1150 & 3300 & 1990 & 1120 & 1800 & 50 & 24 & 12.7 & 166 \\
\hline 8 & 500 & -0.16 & 38000 & 36900 & 2400 & 9820 & 87 & 88 & 1220 & 3470 & 2100 & 1180 & 1890 & 53 & 25 & 13.4 & 174 \\
\hline 9 & 594 & -0.22 & 40500 & 39000 & 2440 & 10500 & 91 & 95 & 1300 & 3720 & 2240 & 1260 & 2000 & 56 & 27 & 14.4 & 185 \\
\hline 10 & 762 & -0.24 & 42700 & 40700 & 2640 & 11200 & 97 & 104 & 1230 & 3940 & 2360 & 1330 & 2110 & 60 & 27 & 15.2 & 195 \\
\hline 11 & 930 & -0.31 & 47400 & 44900 & 2980 & 12500 & 106 & 106 & 1000 & 4380 & 2620 & 1470 & 2330 & 66 & 28 & 17.0 & 214 \\
\hline 12 & 1340 & -0.37 & 53200 & 47700 & 3340 & 14000 & 118 & 125 & 790 & 4930 & 2960 & 1650 & 2630 & 70 & 31 & 19.1 & 239 \\
\hline 13 & 1750 & -0.41 & 52400 & 45900 & 3110 & 13800 & 116 & 124 & 700 & 4920 & 2920 & 1630 & 2610 & 55 & 29 & 19.0 & 234 \\
\hline
\end{tabular}




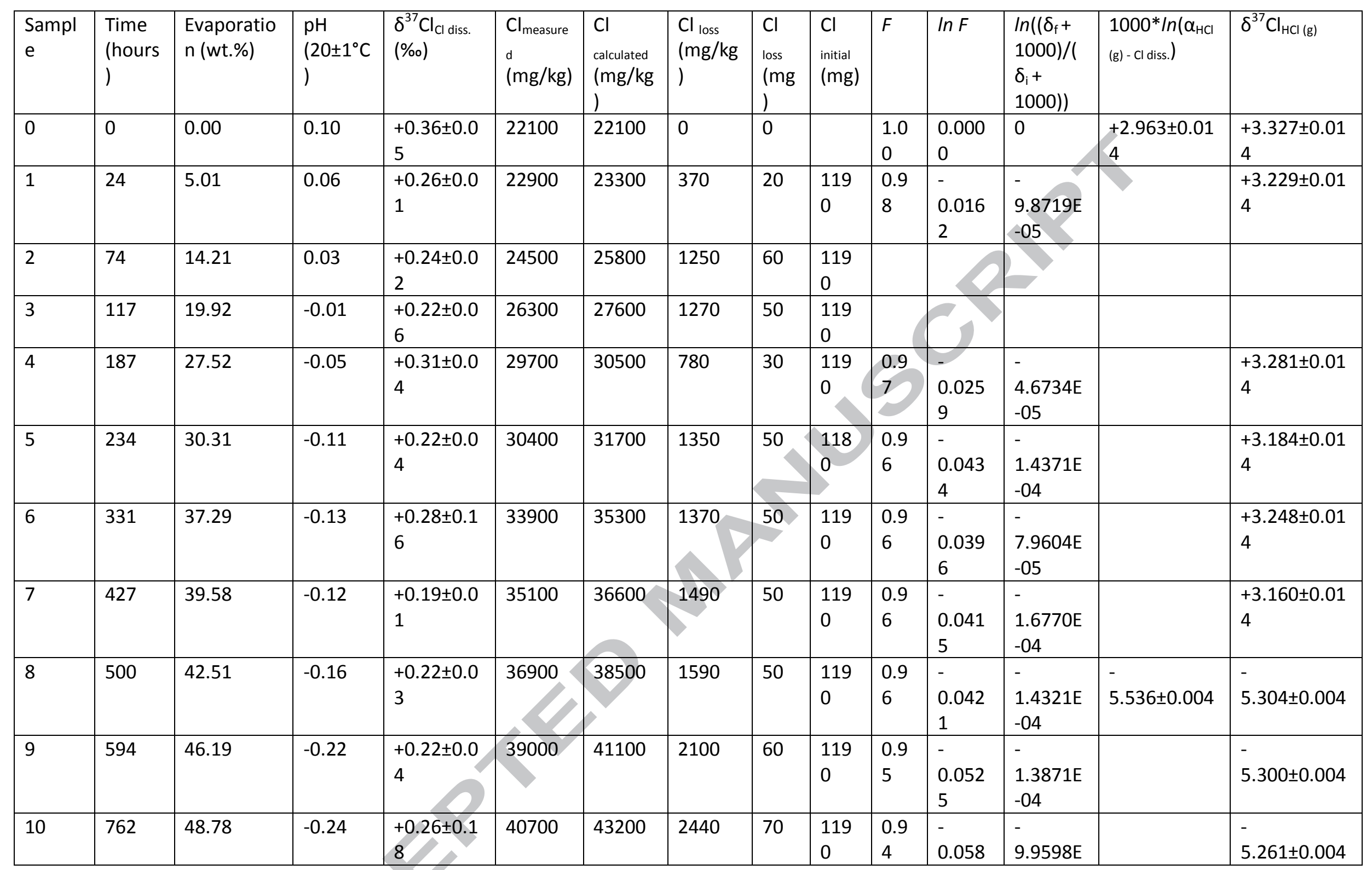




\begin{tabular}{|l|l|l|l|l|l|l|l|l|l|l|l|l|l|}
\hline & & & & & & & & & & 0 & -05 & \\
\hline 11 & 930 & 52.85 & -0.31 & $\begin{array}{l}+0.32 \pm 0.0 \\
4\end{array}$ & 44900 & 46900 & 2020 & 50 & $\begin{array}{l}119 \\
0\end{array}$ & & & \\
\hline 12 & 1340 & 58.05 & -0.37 & $\begin{array}{l}+0.53 \pm 0.0 \\
5\end{array}$ & 47700 & 52700 & 4990 & 110 & $\begin{array}{l}119 \\
0\end{array}$ & $\begin{array}{l}0.9 \\
1\end{array}$ & $\begin{array}{l}- \\
0.099 \\
3\end{array}$ & $\begin{array}{l}1.7017 \mathrm{E} \\
-04\end{array}$ & $\begin{array}{l}- \\
4.991 \pm 0.004\end{array}$ \\
\hline 13 & 1750 & 57.78 & -0.41 & $\begin{array}{l}+0.68 \pm 0.0 \\
5\end{array}$ & 45900 & 52400 & 6510 & 150 & $\begin{array}{l}119 \\
0\end{array}$ & $\begin{array}{l}0.8 \\
8\end{array}$ & $\begin{array}{l}- \\
0.132 \\
6\end{array}$ & $\begin{array}{l}3.1908 \mathrm{E} \\
-04\end{array}$ & \\
\hline
\end{tabular}




\begin{tabular}{|c|c|c|c|c|}
\hline \multirow{2}{*}{ Method } & \multicolumn{2}{|c|}{$t=0-500 h$} & \multicolumn{2}{|c|}{$t=500-1750 h$} \\
\hline & $\boldsymbol{\alpha}_{\mathrm{HCl}(\mathrm{g}) \text { - Cl diss. }}$ & $1000 * \ln \left(\alpha_{\mathrm{HCl}(\mathrm{g})}-\mathrm{Cl}\right.$ diss.) & $\boldsymbol{\alpha}_{\mathrm{HCl}(\mathrm{g}) \text { - Cl diss. }}$ & $1000 * \ln \left(\alpha_{\text {HCI (g) - cl diss. }}\right)$ \\
\hline $\mathrm{Cl}$ independent mass loss & $1.00300 \pm 0.000002$ & $+2.963 \pm 0.014 \%$ & $0.994479 \pm 0.000004$ & $-5.536 \pm 0.004 \%$ o \\
\hline $\mathrm{Cl} / \mathrm{B}$ & $1.00155 \pm 0.00049$ & $+1.55 \pm 0.49 \%$ o & $0.99438 \pm 0.00017$ & $-5.64 \pm 0.17 \%$ \\
\hline $\mathrm{Cl} / \mathrm{Fe}$ & $1.00211 \pm 0.00033$ & $+2.31 \pm 0.33 \%$ & $0.99603 \pm 0.00008$ & $-3.97 \pm 0.08 \%$ o \\
\hline $\mathrm{Cl} / \mathrm{Mg}$ & $1.00337 \pm 0.00111$ & $+3.37 \pm 1.11 \%$ o & $0.99547 \pm 0.00004$ & $-4.54 \pm 0.04 \%$ \\
\hline
\end{tabular}

